\title{
The Maya Footprint: Soil Resources of Chunchucmil, Yucatan, Mexico
}

Ryan V. Sweetwood

Brigham Young University - Provo

Follow this and additional works at: https://scholarsarchive.byu.edu/etd

Part of the Animal Sciences Commons

\section{BYU ScholarsArchive Citation}

Sweetwood, Ryan V., "The Maya Footprint: Soil Resources of Chunchucmil, Yucatan, Mexico" (2008). Theses and Dissertations. 1356.

https://scholarsarchive.byu.edu/etd/1356

This Thesis is brought to you for free and open access by BYU ScholarsArchive. It has been accepted for inclusion in Theses and Dissertations by an authorized administrator of BYU ScholarsArchive. For more information, please contact scholarsarchive@byu.edu, ellen_amatangelo@byu.edu. 
THE MAYA FOOTPRINT: SOIL RESOURCES OF CHUNCHUCMIL, YUCATAN, MEXICO

\author{
by \\ Ryan Van Sweetwood
}

\begin{abstract}
A thesis submitted to the faculty of
Brigham Young University

in partial fulfillment of the requirements for the degree of
\end{abstract}

Master of Science

Department of Plant and Wildlife Science

Brigham Young University

April 2008 
Copyright (C) 2008 Ryan V. Sweetwood

All Rights Reserved 


\section{BRIGHAM YOUNG UNIVERSITY}

\section{GRADUATE COMMITTEE APPROVAL}

of a thesis submitted by

$$
\text { Ryan Van Sweetwood }
$$

This thesis has been read by each member of the following graduate committee and by majority vote has been found to be satisfactory.

Date

Date

Date
Richard E. Terry

Von Jolley

Barry Bickmore 


\section{BRIGHAM YOUNG UNIVERSITY}

As chair of the candidate's graduate committee, I have read the thesis of Ryan Van Sweetwood in its final form and have found that (1) its format, citations, and bibliographical style are consistent and acceptable and fulfill university and department style requirements; (2) its illustrative materials including figures, tables, and charts are in place; and (3) the final manuscript is satisfactory to the graduate committee and is ready for submission to the university library.

Date

Accepted for the Department

Date

Accepted for the College
Richard E. Terry

Chair, Graduate Committee
Brad Geary

Graduate Coordinator
Date
Rodney Brown

Dean, College of Biology and Agriculture 


\title{
ABSTRACT \\ THE MAYA FOOTPRINT: SOIL RESOURCES OF CHUNCHUCMIL, YUCATAN, MEXICO
}

\author{
Ryan V. Sweetwood \\ Department of Plant and Wildlife Sciences \\ Master of Science
}

Agricultural yields in Northwest Yucatán are constrained by climate, thin soils, and low fertility. Despite this, the ancient Maya city of Chunchucmil Yucatán, Mexico, boasted an immense, dense, and wealthy population during the Middle Classic period (ca A.D. 400-700). Soil physical and chemical properties were explored to determine how the ancient Maya of Chunchucmil fed themselves. Soil profiles were collected from various locations within ancient Chunchucmil's suspected sustaining area. The physical and chemical properties, carbon isotopes, black carbon, and coprostanols of soil profiles sampled were compared to ancient rural settlement and remotely sensed images, such as AIRSAR (airborne synthetic aperture radar). Our objectives were to geographically determine the areas of agricultural importance and determine whether evidence of ancient 
agricultural intensification could be observed in the surrounding soil resources of Chunchucmil.

Indigenous Maya of the area identify three major soil classes, boxlu'um, saklu'um, and kancab. The ancient Maya likely preferred kancab because it provided some security with higher soil moisture, greater soil depth, and improved nutrient availability. The land use capability is severely limited in the swamp/estuary and tzekel. The lack of rural settlement within these zones suggests that they were not used for cultivation in ancient times; however, the wood resources likely provided Chunchucmil with vital raw materials. The carbon isotopic signature of ancient $\mathrm{C}_{4}$ crops was not detected suggesting that either maize was not extensively produced or that the mix of native $\mathrm{C}_{3}$ and $\mathrm{C}_{4}$ plants in the savanna hid the signature. There were no soil chemical or biomarker evidences of ancient agricultural intensification, suggesting that ancient agriculture was mainly based on shifting cultivation at Chunchucmil. Concentrations of black carbon, calcium, phosphorus, potassium (Olsen Method), magnesium, and organic carbon within urban and rural settlements were enhanced by incidental human activities.

We determined that the land requirement would have been extensive to sustain the population of Chunchucmil during the Middle Classic based on traditional agricultural methods. The ancient Maya of Chunchucmil likely traded marine and estuary products from the Gulf coast and other high value trade items for agricultural products from the nearby Puuc Hills. 


\section{ACKNOWLEDGEMENTS}

I would like to foremost acknowledge the support of my dear wife, Holly. She has spent many nights alone and has had to console and care for me during the stressful times. She also has exuberated a lot of patience with Dr. Richard Terry for stealing me away to Chunchucmil, Mexico, only days after our honeymoon.

I acknowledge the patience, dedication, and wisdom that the faculty of Brigham Young University has brought to the project. Time, funds, and advice have been afforded me by BYU, which has allowed me to attend many conferences, travel all over the world, and receive an incredible education. Drs. Barry Bickmore, Von Jolley, Steven Petersen, Bruce Webb, and especially Richard Terry were integral in the production of this thesis. I am unable to fully express all that Dr. Terry has done and taught me over the last few years as my mentor.

I am also most grateful for Dr. Timothy Beach of Georgetown University, Dr. Bruce Dahlin, and David Hixson who throughout the project collaborated and assisted me with any need. I am also grateful for the patient local workers of Chunchucmil. They endured my requests and kept me from getting lost in the unforgiving wilds of the Yucatán.

There have been many students who have given of their time to analyze and collect my soil samples. Eric Becker Daniel Bair, Jake Smith, Tim Johnson, and Tyler McKinnon played a major part in this project and deserve special recognition. 


\section{TABLE OF CONTENTS}

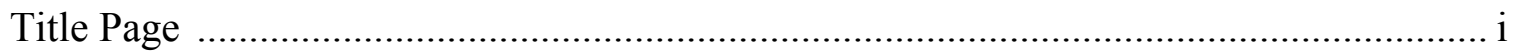

Graduate Committee Approval .................................................................................... iii

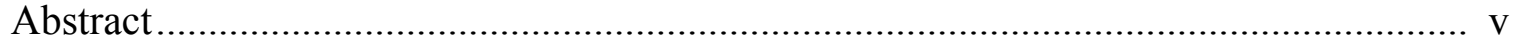

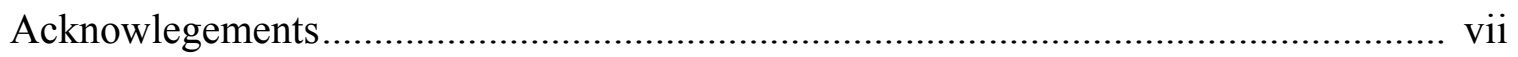

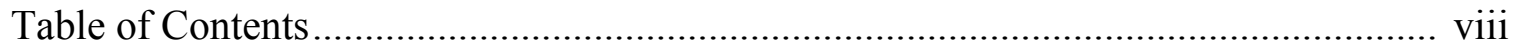

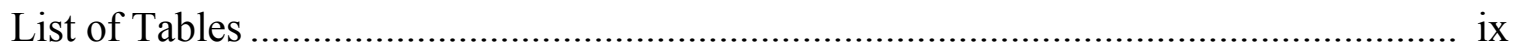

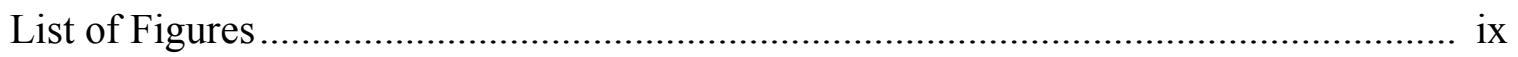

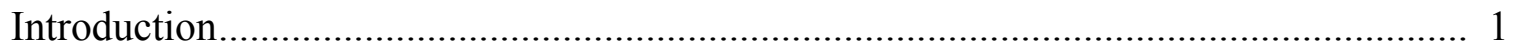

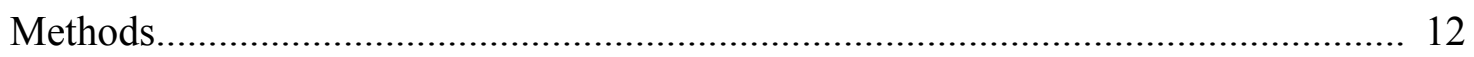

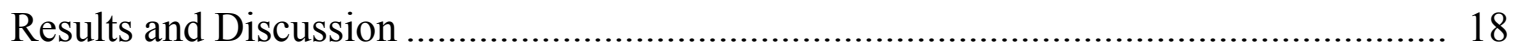

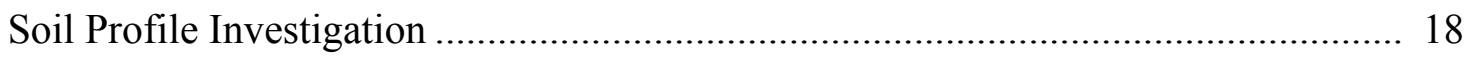

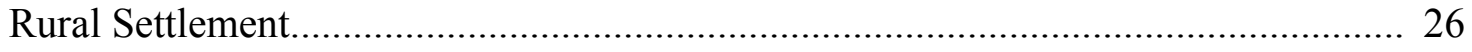

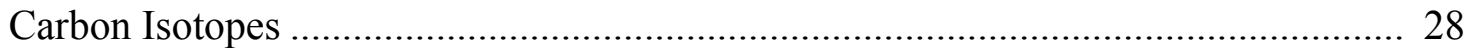

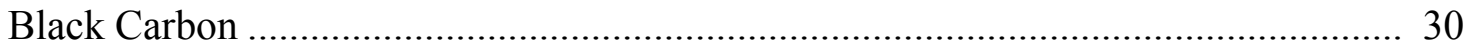

Phosphorus Concentrations and Biomarkers ......................................................... 33

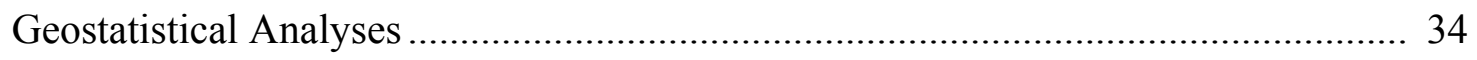

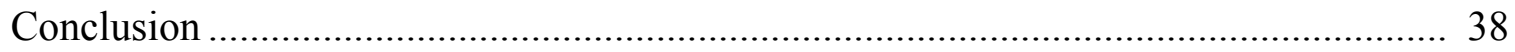

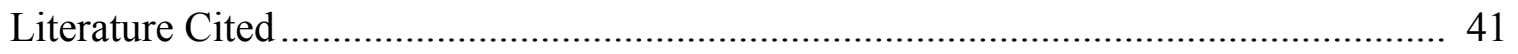

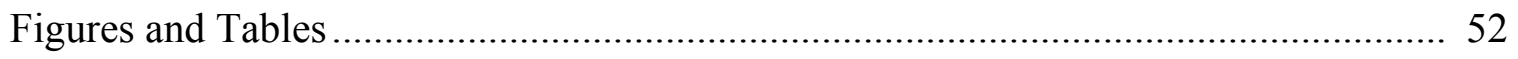

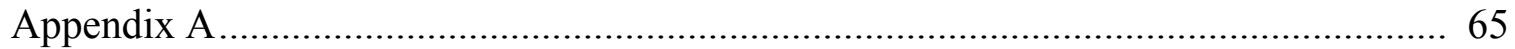


List of Tables

Table 1. Physical and chemical properties of selected representative profiles and mean values of all A horizons for Kancab

Table 2. Physical and chemical properties of selected representative profiles and mean values of all A horizons for Boxlu'um

Table 3. Physical and chemical properties of selected representative profiles and mean values of all A horizons for Saklu'um

Table 4. Soil properties that were significantly different $(P<0.05)$ between boxlu'um from occupied and unoccupied areas.

\section{List of Figures}

Figure 1. Map of ancient Maya cities and vegetative regions in the Northwest Yucatán (courtesy of Dave Hixson).

Figure 2. Map of the central $1 \mathrm{~km}^{2}$ of Chunchucmil. Albarrada (stone fences) groups can be seen as dotted lines. The large stone circle was Chunchucmil's last desperate defense when Chunchucmil was conquered.

Figure 3. Vegetation map of the agricultural resources of Chunchucmil created from an AISAR image (synthetic aperture radar) with locations of ancient Chunchucmil, rural sites, and the area that geospatial analyses were performed (box).

Figure 4. Soil map of great groups under the United States Department of Agriculture classification created using geospatial analysis in ArcMap ${ }^{\circledR}$.

Figure 5. Soil map under the Maya classification created using geospatial analysis in $\operatorname{ArcMap}^{\circledR}$. 
Figure 6. Black Carbon distribution in and around the rural site if Ikmil.

Figures 7. Isopleth map of soil organic carbon across a portion of ancient Chunchucmil's sustaining area.

Figures 8. Isopleth map of soil exchangeable calcium across a portion of ancient Chunchucmil's sustaining area.

Figures 9. Isopleth map of soil profile depth across a portion of ancient Chunchucmil's sustaining area. 


\section{INTRODUCTION}

The ancient Maya city of Chunchucmil located in Yucatán, Mexico, was uniquely situated in the worst agricultural region of the Maya Lowlands, and yet, it boasted an immense, dense, and wealthy population in the Classic period (A.D. 400-700) (Dahlin et al., 2005). Agricultural yields in Northwest Yucatán are constrained today by climate, thin soils, and low soil fertility (Dahlin, 2003; Dahlin et al., 2005; Beach, 1998). Both the modern and ancient environment of Chunchucmil can be described as dry and harsh in the dry season with thin soils or bedrock covering most of the flat karst terrain. Swamp, savanna, tzekel and karst plain make up the four main vegetative zones within the area (Figure 1). From west to east, the vegetation changes from low thorn scrub near the coast, to tall deciduous forest in the tzekel, to low deciduous forest with grasses and sedges in the savanna, and then to taller deciduous forest in the karst plain (Lynch, 1989).

Along the coast are the swamp and estuary lands with petenes or freshwater springs (Figure 1). Preliminary data from the 2005 field season confirmed Beach's (1998) findings that the estuary has a high concentration of surface salts, as much as 14 $\mathrm{dS} / \mathrm{m}$, because of a high water table, making this region unfit for cultivation. The soils of the swamp/estuary zone vary between Histosols, Inceptisols, and Entisols, and they are often covered with periphyton (algal detritus and salts that accumulate in shallow water).

Beach (1998) described the savanna and tzekel zones as ancient sea benches and swales with natural hillocks (tzekeles) of weathered limestone. During the rainy season, a raised water table, high precipitation, and a surface aquitard of weathered capstone cause the savanna to flood. The well-drained hillocks appear as thick, high canopy vegetative islands surrounded by the grassy savanna. 
The karst plain (Figure 1) is the dominant vegetative zone of Northwest Yucatán. Much of this zone is currently used for grazing and cultivation of maize and henequen, but most of the plain is vegetated with grasses and secondary growth. Chunchucmil and rural sites are located within the karst plain

During the Preclassic period, sea levels rose to $60 \mathrm{~cm}$ above pmsl (present mean sea level) and peaked circa A.D. 250-500 to as much as $137 \mathrm{~cm}$ above pmsl (Dahlin et al., 2005). In circa A.D. 500-750, sea levels dropped to $60 \mathrm{~cm}$ below pmsl. This may suggest an increase in arable land and a decrease in estuaries and seasonally inundated savanna (Dahlin et al., 2005) causing the karst plain to possibly expand to the west (Beach, 1998).

The most distinctive features of the soils of Chunchucmil are their generally poor quality and shallow depth (Dahlin et al., 2005; Beach, 1998; Weisbach et al., 2002). Approximately 55 to $80 \%$ of the area has thin to no soil and between 25 and $50 \%$ lacks any soil at all (Dahlin et al., 2005). With slopes of less than $1 \%$, this area has the thinnest soils and is the most planar area of all of the Maya Lowlands (Beach, 1998; Dahlin, 2003). Often in the Maya Lowlands shallow soils are due to erosion, but the lack of slope here in the flat karst plain suggests that the absence of soil is not caused by erosion; rather, it is due to the porous nature of the karst topography (Kellman and Tackaberry, 1997) and slow soil development. Curtis et al. (1996) and Beach (1998) concluded that the present fertility and depth of the soils would not have been much different than during the Maya occupation because no period of increased soil erosion previously existed, due to the areas shallow slope and clayey soils. 
Sahkab lu'um or saklu'um (sahkab-white, lu'um-earth or soil), boxlu'um (boxlight black), and kancab lu'um (kan-yellowish, Cab-reddish syrup), as they are distinguished under the Mayan classification based on color (Barrera-Bassols and Toledo, 2005), are the three dominant soil types in ancient Chunchucmil's sustaining area (Weisbach et al., 2002). Soil development began in the Late Miocene to Pliocene (Pope et. al, 1996). With an average annual soil temperature of $29.4^{\circ} \mathrm{C}$, the soil temperate regime is classified as isomegathermic and the soil moisture regime as ustic (Eswaran et al., 1997). Ustic moisture regimes are moisture limited except during a certain period time each year (Soil Survey Staff, 2003).

Saklu'um is a gray shallow sandy loam or clay loam over a cemented capstone. Saklu'um is found in the swamp and in areas of the tzekel that are seasonally inundated. This soil is rocky and high in carbonates and surface salts (Beach, 1998). Boxlu'um is shallow, clay loam (Calciustolls, Paleustolls, or Haplustolls), and high in carbonates that formed in fractured cobble and gravel limestone (Beach, 1998). It is most commonly found on raised areas like in the tzekel or in anciently occupied areas. The Maya also classified soil based on texture, structure, and consistence, and soil of the tzekel is also called tzekel lu'um (tzekel-flat stone) (Barrera-Bassols and Toledo, 2005). Field reconnaissance of densely occupied areas of ancient Chunchucmil showed that boxlu'um was present on the house mounds and platforms despite the presiding vegetative zone and surrounding kancab soils. Building materials and other human activity have altered soil conditions. Kancab is higher in clay (Paleustalfs, Paleustolls, and Haplustalfs), deeper, and less stony than boxlu'um (Beach, 1998). Boxlu'um tends to have a relatively high nutrient status with higher organic matter and available macro and micronutrients when 
compared to kancab (Weisbach et al., 2002). Boxlu'um and saklu'um are slightly alkaline and kancab is neutral. Saklu'um, kancab, and boxlu'um have relatively low electrical conductivity (EC).

The current occupants of Chunchucmil commented that they prefer boxlu'um for agriculture (Dahlin et al., 2005), but other farmers in Northwest Yucatán have stated that kancab is more productive (Weisbach et al., 2002). These seemingly contradictory statements were clarified by Weisbach et al. (2002). They concluded that there is a strong link between soil moisture and nutrient availability. Low soil moisture reduces the mobility of nutrients and decreases plant uptake. Since boxlu'um tends to have soil moisture and hydrophobic properties, the available nutrients do not reflect the fertility of this soil class. Conversely, kancab remains slightly moist in the subhorizons even in the driest conditions. The modern Maya have been observed to maintain many milpas (maize fields) in diverse locations to ensure crop success and decrease the probability of a disaster from variable amounts of rain (Sharer, 1994).

Beach (1998) and Weisbach et al. (2002) agree that phosphorus (P), potassium (K), and zinc (Zn) are limited at Chunchucmil, and Zech et al. (1991) add that nitrogen $(\mathrm{N})$ and manganese $(\mathrm{Mn})$ may also be included. Approximately 30 to $50 \%$ of the trees are legumes (Rico-Gray et al., 1988), which maintain a low C:N (carbon:nitrogen) ratio in undisturbed soil (Beach, 1998). However, after only one year of cultivation, total $\mathrm{N}$ is reduced by approximately $20 \%$ in soils of the Yucatán (Weisbach et al., 2002). Soil N quickly becomes a limiting nutrient in the already nutrient-limited soil.

The climate of Northwest Yucatán has probably varied little since the Maya occupation (Dahlin, 1983). It is semi-arid with unpredictable weather and precipitation 
(Beach, 1998; Dahlin et al., 2005; Me-Bar and Valdez, 2003). The year begins with a dry season of about four to five months (January to May) (Grube, 2000), of which the hottest months are from March to May. The average annual temperature is $27.2^{\circ} \mathrm{C}$ (Querejeta et al., 2007). The rainy season is from May to October; rainfall is extremely variable from year to year and even throughout a single year (Dunning and Beach, 2000; Dahlin, 1983; Beach, 1998). Some years have as much as 3 to 4 times more rain than others (Lundell, 1934). The majority of rainfall (80-90\%) (Beach, 1998) falls during the growing season, approximately 640-900 $\mathrm{mm}$ (23-35 in), and Chunchucmil has a mean annual waterbudget deficit of 600-700 mm (Instituto Nacional de Estadística, Geografía e Informática, 1983; Luzzadder-Beach, 2000; Dahlin et al., 2005). In comparison, southern Belize's annual rainfall is between 3,000 and 4,000 $\mathrm{mm}$ (Grube, 2000).

Chunchucmil was first occupied in the Middle Preclassic period (B.C. 500-200) and population substantially decreased in the Late Classic period (A.D. 800-900) (Dahlin, 2003). Its major period of occupation was the Middle Classic (ca. A.D. 400-700) (Dahlin et al., 2005). Chunchucmil had a peak population of 42,400-47,600 in its $21 \mathrm{~km}^{2}$ central area along with a large regional population, and was the most densely populated city in all of the Maya Lowlands (see Figure 2) (Dahlin et al., 2005).

Other large Maya sites near Chunchucmil (Figure 1) include the ancient coastal site of Punta Canbalam (27 km), Siho to the south $(20 \mathrm{~km})$, and Oxkintok to the eastsoutheast $(30 \mathrm{~km})$, all of which were contemporaneous with Chunchucmil's major period of occupation (A.D. 400-700) (Dahlin et al., 2005). Punta Canbalam was an ancient port city known for the second largest salina (coastal area used for salt harvesting) in the Maya Lowlands (Dahlin et al., 1998). 
The urban area of Chunchucmil (Figure 2) was made up of patio groups that housed extended families and are surrounded by an albarrada (low stone fence) that bound each lot (solar) (Dahlin et al., 2005). The solares ranged in size from 0.075 ha to 0.75 ha (median $=0.253 \mathrm{ha}$ ) (Hutson et al., 2006) and approximately $60 \%$ of the median solar size was taken up by structures (Killion, 1992). These solares were not large enough to substantially contribute to agricultural self-sufficiency (Dahlin, 2003).

Temples, mounds, albarradas, and even the hastily built barricade from the Terminal Classic remain relatively intact and demonstrate that this region has been largely left undisturbed. Minimal residual populations have occupied this region since the Terminal Classic. Some historic disturbances included henequen plantations and, more recently, a few minor agricultural programs supported by the Mexican government (papaya, aloe vera, citrus, and chili) (Dahlin, 2003).

The modern village of Chunchucmil today is home to approximately 1,000 people (Luzzadder-Beach, 2000), of which only a small percentage currently practice milpa agriculture (shifting cultivation, slash-and-burn agriculture) (Beach, 1998) while the rest supplement their income with ranching or jobs in nearby cities. These few milperos (maize farmers) have the opportunity to cultivate the more fertile soils of the region, and yet compared to the average world maize yield of 4.6 metric tons ha ${ }^{-1}$ (PinstrupAnderson, 1994), maize yields in this area are still extremely low and erratic: as high as 0.25 to 1 metric ton ha ${ }^{-1}$ in a good year (Beach, 1998) and as low as 0.1 metric ton ha ${ }^{-1}$ (Shuman, 1974). Even during the henequen era, the plantation at Chunchucmil produced half as much as those plantations farther east (Vlcek et al., 1978). The most common agricultural practice among the modern Yucatec is shifting cultivation. Shifting 
cultivation was likely as effective anciently as it is today in the Maya Lowlands (Hester, 1953) and it is supposed that the Maya obtained similar crop yields.

Maize cultivation is restricted to one crop per year for about two to three years. High EC in groundwater (Luzzadder-Beach, 2000) and inadequate access to wells and sascaberas (ancient limestone quarries that occasionally retain water) restricts cultivation to the rainy season. The short cultivation period is attributed to a reduced crop yield that is caused by decreased organic matter, soil moisture, and nutrient availability, and increased weed competition (Reina, 1967; Reina and Hill, 1980; Dahlin et al., 2005; Beach, 1998; Weisbach et al., 2002; Emerson, 1953; Dalle and de Blois, 2006; Cogwill, 1960).

During fallow, secondary growth of shrubs, weeds, vines, grasses, and young trees (Emerson, 1953; Dalle and de Blois, 2006) quickly overtakes the milpa and allows the natural process of reclamation of the soils. The time required for fallowing depends on the type of soil and the length of time that the land was cultivated (Weisbach et al., 2002). Generally it is 7 to 15 years of fallow for every 2 to 3 years of cultivation in the Maya Lowlands, a need of 2 to 7 times more land in fallow than in cultivation (Reina, 1967; Reina and Hill, 1980). Weisbach et al. (2002) concluded that for Northwest Yucatán a 12-year fallow restored most of the nutrient status, but recommended a 25-year fallow to have the most significant improvement. Recent demand for increased crop production has dictated that the recommended fallow time be cut in half or more, requiring about a 10-year fallow (Dahlin et al., 2005).

In the 2005 field season, several families east of Chunchucmil were observed dryfarming maize and one local family was interviewed. They stated that groundwater was 
used and carried in pots to every stalk nearly every day. This is labor intensive and similar to what would be expected if the ancient Maya had also practiced dry-farming. For dry-farming to have been intensively incorporated into Chunchucmil's subsistence systems, there must have existed a plethora of wells or sascaberas, but a lack of excavated modern and ancient wells (a total of 20) and sascaberas suggests otherwise (Dahlin et al., 2005). To complicate the situation further, intensive irrigation on milpas or home gardens would reduce crop yields and damage susceptible crops (especially seedlings) due to salt accumulation (Luzzadder-Beach, 2000). Luzzadder-Beach's (2000) studies of the water resources of Chunchucmil showed that the average EC for two field seasons were $1.2 \mathrm{dS} / \mathrm{m}$ and had ranges of 0.5 to $2.0 \mathrm{dS} / \mathrm{m}$ and 0.3 to $3.1 \mathrm{dS} / \mathrm{m}$. Chunchucmil groundwater values can reduce maize yields 0 to $35 \%$ if exclusively applied (Luzzadder-Beach, 2000). Maize agriculture was, therefore, likely restricted to the rainy season because of lack of access to groundwater and unfavorable EC levels in groundwater.

Early studies of the modern Yucatec Maya showed that maize made up about $85 \%$ of the Maya's diet (Emerson, 1953), which equates to a little more than 0.2 metric ton of maize per year per person (Shuman, 1974; Steggerda, 1941). This demands a land requirement of 0.2 to 2 ha/person with modern crop yields from this region of $0.1-1$ metric ton/ha. Dahlin et al. (2005) conservatively estimated the sustaining area of Chunchucmil to be $1,600 \mathrm{~km}^{2}$ using a Thiessen polygon, but he stated that what was actually available to them must be significantly less because of major overlapping with Siho's and Oxkintok's sustaining areas. The area is further reduced to roughly $800-1,200$ $\mathrm{km}^{2}$ when structures and areas with no soil cover (25-50\%) are excluded. The seasonally 
inundated savanna is considered unfit for cultivation (Garza and Kurjack, 1981) and reduces the sustaining area to Beach's (1998) proposed estimate of $600 \mathrm{~km}^{2}$.

Since the mid 1990's Timothy Beach, geomorphologist of Georgetown University, Bruce Dahlin, archaeologist of Howard University, and many others (Hixson, 2004; Hutson, 2007; Vlcek, 1978; Farnell et al., 1996; Magnoni, 2004; Arden et al., 2003) have been investigating the economy and soil resources of the Chunchucmil region as part of the Pakbeh Regional Economy Program. Due to the lack of soil resources, the enormity of the site, and the assumption that Maya households were agriculturally selfsufficient (Drennan, 1984a, 1984b; Sanders and Webster, 1998), the subsistence economy needed to be re-examined (Dahlin et al., 2005). From their investigations, Beach (1998) and Dahlin et al. (2005) infer that the lack of food-producing structures, insufficient sustaining area, and poor soil resources may indicate that agriculture was based on atypical crops or methods or that food trade would have been required to supplement the food resources that couldn't have been produced at Chunchucmil using traditional agricultural methods.

This study furthers the investigation of soil resources done by the Pakbeh Regional Economy Program in an attempt to answer the question that Beach (1998) posed, "How did ancient Maya high populations feed themselves?" The main objectives of this study were to:

1. Determine geographically the areas of agricultural importance,

2. Identify evidence of agricultural intensification of soils by night soiling (fertilizing with fecal matter) and soil amendments with charcoal, and 
3. Determine whether evidence of ancient agricultural intensification could be observed in the surrounding soil resources of Chunchucmil.

Areas of agricultural importance can be identified through soil physical, chemical, and fertility analyses and land evaluations. Carbon isotopes, ancient rural settlement, and remotely sensed images, such as AIRSAR (airborne synthetic aperture radar) can also aid in delineating probable areas of ancient agriculture.

Carbon isotopic ratios $\left({ }^{13} \mathrm{C} /{ }^{12} \mathrm{C}\right)$ have been used to identify ancient long-term maize cultivation at other sites in the Maya Lowlands (Wright, 2006; Burnett, ND; Fernández, 2005). A maize $\mathrm{C}_{4}$ signature is formed when long-term maize cultivation takes place in a normally $\mathrm{C}_{3}$ vegetative region which leaves a $\delta^{13} \mathrm{C}$ enriched horizon. Many tropical and subtropical grasses, including maize, possess a $\mathrm{C}_{4}$ photosynthetic process that is less discriminatory against the heavier ${ }^{13} \mathrm{C}$. These $\mathrm{C}_{4}$ plants have an average $\delta^{13} \mathrm{C}$ value of about $-12 \%$ (Boutton, 1991, 1996; Balesdent and Balabane, 1992). The trees and vines of rain forest vegetation possess a $C_{3}$ photosynthetic system that is very discriminatory toward ${ }^{13} \mathrm{C}$ and their average $\delta^{13} \mathrm{C}$ is $-27 \%$ (Boutton, 1991, 1996; Balesdent and Balabane, 1992). The isotopic signature of these different vegetation types is transferred to the humic substances of the soil as the plant detritus is decomposed and organic fragments are incorporated into the soil organic matter. A shift in the $\delta^{13} \mathrm{C}$ of the humus greater than $-4 \%$ within a soil profile is strong evidence that there has been a change in the vegetation type, from forest vegetation to savanna or to maize agriculture for a sustained period of time (Boutton, 1996; Webb et al., 2003, 2007; Johnson et al., 2007; Wright, 2006). 
The AISAR images will be used to create a map of the vegetative zones and geographically compare the map and rural settlement. We hypothesize that there is a difference in land capability between the soil classes, and that density of rural settlement will correlate with land capability and carbon isotopes.

Certain chemical residues like biomarkers, $\mathrm{P}$, and black carbon (BC) have the potential to indicate intensive agriculture. For Chunchucmil to have been agriculturally self-sufficient, large inputs of plant essential nutrients and organic matter $(\mathrm{OM})$ were needed to increase yields and shorten fallow time. These inputs over several centuries should have left a detectable imprint on the soils of this area. For example, large regions in the Amazon jungle were anciently amended with copious amounts of charcoal (BC) such that they are still highly fertile today (Costa et al., 2004; Mann, 2002; Schaefer et al., 2004). We hypothesize that, if charcoal was used as an amendment, there would be a difference in $\mathrm{BC}$ concentrations between unoccupied and occupied areas with higher levels of $\mathrm{BC}$ in the ancient fields. We also hypothesize that there would be a greater concentration of stanol biomarkers and soil $\mathrm{P}$ in potential areas of ancient agriculture if night soiling occurred. Patterns of high concentrations of $\mathrm{P}$, potentially many times greater than background levels, would appear in the ancient fields if they were amended with night soil. Agricultural intensification like soil importation, soil amendments, and fertilizing with organic amendments could have elevated certain soil properties above natural background concentrations. Therefore, we compared several soil chemical properties as possible indicators of human activity in both occupied areas and surrounding unoccupied fields. 


\section{METHODS}

\section{Collection of Profile Soil Samples}

Bon and Nah Caña were two tertiary sites without site cores or temples and Pocholchen and Ikmil were medium secondary sites that possessed both site cores and pyramid structures (Hixson, ND). These sites are located directly west of ancient Chunchucmil and exhibited several different ecosystems and soil types (Figure 3). In the tzekel area ancient sea benches are aligned in a northeasterly direction. These sea benches create rises and depressions, causing the vegetation and soil characteristics to change with these slight changes in elevation. To increase the probability of observing a change in soil class, transects outside of Chunchucmil proper were sampled west to east, nearly perpendicular to the ancient sea benches.

Three $\sim 2 \mathrm{~km}$ transects - northeast, east, and northwest - were selected starting within the core area of Chunchucmil, and soils were collected every 100 meters. Settlement was also mapped along these transects as part of the Pakbeh Regional Economy Program in 2006. Soil was excavated from each profile to bedrock and field observations, GPS coordinates, and photographs were collected for each profile. Soil sampling was based on horizon for most profiles. For soil profiles excavated in 2005 that

were deeper than $20 \mathrm{~cm}$, multiple soil samples were taken every $15 \mathrm{~cm}$ for ${ }^{13} \mathrm{C} /{ }^{12} \mathrm{C}$ ratio analysis. In order to compare BC data, surface soil samples were collected on mound (ancient house mound), near mound, and off mound (areas that could have been used for milpas). 


\section{Sample Preparation}

All samples were collected in a plastic bag and air dried as much as possible while in Chunchucmil prior to shipping to preserve soil properties. Soil samples were air dried upon arrival at the Brigham Young University Soil Analysis Laboratory, Provo, UT, and then aggregates were crushed and sieved $(<2 \mathrm{~mm})$.

Physical Characterization

Field observations included soil color using a Munsell color chart, structure, horizon depth, and vegetative type and canopy height. Laboratory analyses included gravel percent by weight and texture by hydrometer method. Profiles were classified using the USDA soil taxonomy system (Soil Survey Staff, 2003). Water repellency was examined using the water droplet penetration test (WDPT) that tests the amount of time needed for water to penetrate the soil (King, 1981). Soils were classified based on the seven classes of repellency: Class 0 , wettable, nonwater repellent (infiltration within $5 \mathrm{~s}$ ); Class 1, slightly water repellent (5-60 s); Class 2, strongly water repellent (60-600 s); Class 3, severely water repellent (600-3600 s); and extremely water repellent ( $>1 \mathrm{~h})$, which is further subdivided into Class 4,1 to $3 \mathrm{~h}$; Class 5, 3 to $6 \mathrm{~h}$; and Class 6, >6 h. (Dekker et al., 2001).

\section{Chemical Characterization}

Chemical analyses were selected to estimate soil fertility potential. Methods included the determination of $\mathrm{pH}$ by glass electrode (1:1 soil:water ratio), $\mathrm{CaCO}_{3}$ equivalent by titration, and $\mathrm{EC}(\mathrm{dS} / \mathrm{m})$ of the saturated extract by Beckman Electrical 
Conductivity Bridge. The total carbon and nitrogen concentrations were determined using a LECO TruSpec C/N Determinator (Thermo Fisher Scientific Inc., St. Joseph, Michigan). Soil P and K were extracted by the sodium bicarbonate method (Olsen method); the extractable $\mathrm{P}$ is measured by colorimetry and extractable $\mathrm{K}$ on the atomic absorption spectrophotometer (AA). Chelate extractable micronutrients iron (Fe), $\mathrm{Mn}$, $\mathrm{Zn}$, and copper $(\mathrm{Cu})$ were treated with DTPA (diethylenetriaminepentaacetic acid) (Parnell et al., 2002) and concentrations were determined with a Thermo Jarrell Ash inductively coupled plasma atomic emission spectrometer (ICP AES) (Waltham, Massachusetts). Exchangeable cations calcium (Ca), sodium ( $\mathrm{Na})$, magnesium $(\mathrm{Mg})$, and $\mathrm{K}$ were extracted with ammonium acetate and ion concentrations were determined by ICP AES. Cation exchange capacity (CEC) used $\mathrm{NaOAC}-\mathrm{NaCl}$ and the aliquot was analyzed on the AA.

\section{Carbon Isotopes}

Stable carbon isotope ratios $\left({ }^{13} \mathrm{C} /{ }^{12} \mathrm{C}\right)$ were determined following removal of carbonates and extraction of humic acid, and fulvic acids from the samples. The residual humin in the soil analyzed on an isotope ratio mass spectrometer coupled with an elemental analyzer. Soil samples were ground and passed through a 60-mesh sieve $(<0.25 \mathrm{~mm})$. Approximately $5 \mathrm{~g}$ were weighed into tubes and placed in a rotating water bath at $70^{\circ} \mathrm{C}$. Carbonate was removed with $1 \mathrm{M} \mathrm{HCl}$ added in increments until effervescence ceased. The humic and fulvic fractions of the soil organic matter (SOM) were extracted with alkaline pyrophosphate solution (Webb et al., 2003; Wright, 2006). Samples were transferred to $50 \mathrm{ml}$ polypropylene Oak Ridge centrifuge tubes, washed 
twice with distilled water, and $25 \mathrm{ml}$ of $0.1 \mathrm{M} \mathrm{NaOH}+0.1 \mathrm{M} \mathrm{Na}_{4} \mathrm{P}_{2} \mathrm{O}_{7}$ (pyrophosphate) solution were added. The headspace gases were purged with nitrogen gas, and the samples were shaken overnight. This step was repeated two more times. Between each step the samples were centrifuged at 10,000 rotations per minute for 30 minutes and the extracted humic acids were decanted. Next, $25 \mathrm{ml}$ of $0.05 \mathrm{M} \mathrm{H}_{3} \mathrm{PO}_{4}$ was added, shaken, and centrifuged and repeated once more with $25 \mathrm{ml}$ of $0.025 \mathrm{M} \mathrm{H}_{3} \mathrm{PO}_{4}$. A final rinse with distilled water was required to remove residual acid and salts. The samples were then dried in an oven $\left(105^{\circ} \mathrm{C}\right)$, ground again to $60 \mathrm{mesh}$, and weighed for analysis. The

${ }^{13} \mathrm{C}$ isotope ratios of the humin fractions were determined with a Finnigan Delta Plus isotope-ratio mass spectrometer (Isotech Laboratories Inc., Champaign, Illinois) coupled with a Costech Elemental Analyzer (Costech Analytical Technologies, Inc., Valencia, California).

\section{Black Carbon}

Estimation of soil charcoal using benzene polycarboxylic acids (BCPA) was determined by trifluoroacetic acid (TFA) and $\mathrm{HNO}_{3}$ digestions and analyzed on the FIDgas chromatograph (Agilent Technologies, Santa Clara, California) with a HP-1 capillary column $(25 \mathrm{~m} \times 0.32 \mathrm{~mm} \times 0.17 \mu \mathrm{m})$. This method was developed by Glaser et al. (1998) and revised by Brodowski et al. (2005).

Carbonate free soil samples $(0.25 \mathrm{~g})$ were treated with $2 \mathrm{ml}$ of $4.0 \mathrm{M}$ TFA at $105^{\circ} \mathrm{C}$ for 4 hours in culture tubes with Teflon lined lids. The samples were cooled, centrifuged, and rinsed with more 4.0 M TFA and DD water and the supernatants were disposed. The soils were digested with of $2 \mathrm{ml}$ of concentrated $\mathrm{HNO}_{3}$ for 8 hours at 
$120^{\circ} \mathrm{C}$, after which samples were cooled and filtered through glass fiber filter.

Multivalent cations in the digest were removed before derivitization as it was passed through a Bakerbond SPE Octadecyl (C18) extraction column (Mallinckrodt Baker, Inc., Phillipsburg, New Jersey). The column was activated with $2 \mathrm{ml}$ of methanol and was then rinsed with $12 \mathrm{ml}$ of DD water. An aliquot of digest was pushed through the column followed by $6 \mathrm{ml}$ of $1 \mathrm{M}$ acetic acid and $12 \mathrm{ml}$ of DD water. The column was then eluted with $3 \mathrm{ml}$ methanol and collected in acetone-rinsed vials and evaporated.

Benzenepolycarboxylic acids were derivatized with $0.1 \mathrm{ml}$ of pyridine and $0.1 \mathrm{ml}$ of N,Obis trimethlsilyl-trifluoroacetamide for 2 hours at $80^{\circ} \mathrm{C}$. The $\mathrm{BC}$ was analyzed on the FID-gas chromatograph and they were summed to calculate total BC.

Statistical Analysis

All statistical analyses were performed on Microsoft Excel, except for the Anderson-Darling test for normality which was performed on SAS. Single factor ANOVA and Kruskel-Wallis were used for comparisons depending on normality and sample size.

Land Evaluation

A land capability classification system was developed by the USDA (Klingebiel and Montgomery, 1961) and applied to these soils. Classes I through IV are suited for cultivation while Classes V through VIII are land limited and recommended for other uses, i.e. pasture, range, woodland, wildlife food, water supply, and cover. Agricultural 
limitations increase with each class that restrict the choice of plants and require more management.

GIS and Mapping

Geostatistical analyses (kriging) were performed in $\operatorname{ArcMap}^{\circledR}$ to create a contour map and summarize soil properties over part of Chunchucmil's sustaining area. Isopleth maps were created and compared to each other and to an AIRSAR image. Due to Chunchucmil's large sustaining area, only a part could be sampled and analyzed, but the intrapolated areas do cover, in part, all of the vegetative zones. In a similar manner we created soils maps using USDA system as well as maps created using the Mayan classification system.

The vegetation map (Figure 3) was created using an AIRSAR image taken in 2004 during the height of the dry season (Hixson, ND). Synthetic aperture radar is a remote sensing technology that produces high resolution, polarized images (Lou et al., 1996). Using ERDAS Imagine ${ }^{\circledR}$ GIS software (Leica Geosystems Geospatial Imaging, Norcross, Georgia), we applied both a supervised and unsupervised classification in attempt to detect the primary feature classes that occur with the Chunchucmil's sustaining area. 


\section{RESULTS AND DISCUSSION}

Soil Profile Investigation

The soil physical and chemical properties were explored and compared to

AIRSAR images to delineate probable areas of agricultural importance. An evaluation of the capabilities of each indigenous Mayan soil class could illustrate potential uses of the surrounding resources of Chunchucmil.

The three main Mayan soil classes for this area, boxlu'um, kancab, and saklu'um, were distinct from one another. The soil physical and chemical properties of representative profiles are listed in Tables 1, 2, and 3. A complete listing of all soil profiles and their physical and chemical properties are presented in Appendix Tables A-1, A-2, and A-3. Average values of soil physical and chemical properties for all A horizons for each Mayan soil type are also presented in Tables 1, 2, and 3. Kancab consisted of shallow $(8$ to $50 \mathrm{~cm})$, moderately well drained soils over a caliche or petrocalcic horizon underlain by less dense, frail carbonate rock (sascab) (Beach, 1998). The sascab provided deep-rooted vegetation with a water source during the dry season as it is porous and retains water (Stevens, 1964). Kancab was reddish brown (5YR 4/4), clay loam that was noneffervescent with neutral $\mathrm{pH}$. Boxlu'um consisted of extremely shallow (3 to 25 $\mathrm{cm})$, well drained soils over fractured limestone. Boxlu'um was black (10YR 2/1), skeletal, very gravely clay loam with slightly alkaline pH. Saklu'um consisted of extremely shallow (3 to $17 \mathrm{~cm}$ ), moderately well drained calcareous soils over petrocalcic pavements. Saklu'um was grayish brown (2.5Y 5/2), sandy clay loam with 
effervescence, and slightly alkaline $\mathrm{pH}$. These soils formed in sandy and loamy marine sediments from the Quaternary and Pliocene (Dahlin et al., 2005).

Of 91 soil profiles classified under the USDA soil taxonomy in this study area $80 \%$ belonged to the soil order Mollisols, $11 \%$ to Entisols, $8 \%$ to Alfisols, and $2 \%$ to Inceptisols. In general, Mollisols have high base saturation, high OC content, and usually a mollic epipedon, and are relatively fertile (Buol et al., 2003). Entisols are often shallow soils that have recently formed. Alfisols form in forest stable conditions and can be naturally fertile. Inceptisols bare close resemblance to their parent material and are slightly more developed than Entisols. There were 7 different great groups observed in the study area: (1) Haplustolls (14\% of profiles) occurred in the well-drained boxlu'um; (2) Calciustolls (15\% of profiles) occurred in both boxlu'um and kancab; (3) Paleustolls ( $51 \%$ of profiles) occurred in both boxlu'um and kancab; (4) Ustorthent ( $2 \%$ of profiles) occurred in boxlu'um; (5) Paleustalf (8\% of profiles) occurred in kancab; (6) Endoaquent ( $8 \%$ of profiles) occurred in saklu'um; and (7) Petraquept (2\% of profiles) occurred in saklu'um.

The seven great groups from USDA soil taxonomy systematically fit within the three Mayan classifications, although some great groups appeared in more than one Mayan class. Separating the great groups by the Mayan classification helped partition the great groups according to geographic position since saklu'um, boxlu'um, and kancab occurred from west to east within the study area, respectively. We then created histograms of the frequency of great groups that occurred in each Mayan classification and designated them on a scale of 1 to 7 . The most frequented great groups in each Mayan class were assigned 2 for saklu'um, 4 for boxlu'um, and 6 for kancab. Those 
great groups in kancab and saklu'um that did not share soil orders or great groups with great groups in boxlu'um were designated as the polar ends, 1 and 7 , and those that did share soil orders or great groups were designated as 3 and 5. A map of saklu'um, boxlu'um, and kancab was created by ranking them as they occurred west to east.

Soil maps were created from this numerical categorization of the USDA classification and Mayan classification using geospatial analysis in $\operatorname{ArcMap}^{\circledR}$ (Figures 4 and 5) and these maps demonstrated that the majority of Chunchucmil's sustaining area was likely Paleustalfs. Although the majority of the soil profiles sampled were Mollisols, all transects intersected settlement and profiles were located on or near house mounds, upon which Mollisols formed over the past 1200 years. Frequent and small changes in microrelief throughout this region cause several types of soil to exist in a relatively small area. If a true soil map were created, the resultant map would not be a gradient as Figures 4 and 5; rather, it would be more of a collage of islands and interfingered classes in each region. Instead, these maps represent the most likely soil class to occur in that region. AIRSAR images illustrated many features about the area and have potential for ecological (Pope et al., 1994; Freeman et al., 2002) and archaeological investigations (JPL, 2008). The three most apparent features for this area are cleared or deforested areas devoted to grazing or milpas, ancient and modern settlement, and change in height of canopy, which is most indicative of change in vegetative zone. A vegetation map (Figure 3) that included all documented secondary and tertiary sites of Chunchucmil (Hixson, ND) was created based on canopy height that was visible in the AIRSAR image. Based on knowledge of the area, areas of the tzekel with tall canopy appeared as white or a lighter color than its surroundings. We attempted to use both a supervised and 
unsupervised classification to delineate the primary feature classes that occur with the Chunchucmil's sustaining area; however, poor resolution, extreme pixilation, and distortion of the image made the resulting map uninterpretable and inaccurate. Even after applying a convolution filter to reduce the affects of pixilation, the image could not be accurately classified using GIS. Therefore, the vegetation map was created by hand (digitized in $\operatorname{ArcMap}^{\circledR}$ ) based on canopy height that was visible in the AIRSAR image. It proved impossible to distinguish the subtle change between savanna and karst plain, so a gradient based on soil profile descriptions was drawn to show the subtle transition from savanna to karst plain. Areas of mixed vegetation of high and low canopy were delineated based on whichever vegetative appeared predominant. Both soil maps were overlaid the vegetation map and soil change generally coincided with change in vegetation.

Alkaline soils similar to those of Chunchucmil are inclined to exhibit deficiencies of $\mathrm{P}, \mathrm{Fe}, \mathrm{Mn}$, boron, $\mathrm{Cu}$, and $\mathrm{Zn}$. The concentrations of macronutrients $(\mathrm{P}, \mathrm{K})$ and micronutrients $(\mathrm{Cu}, \mathrm{Zn}, \mathrm{Mn}, \mathrm{Fe})$ for each Mayan soil class (Tables 1, 2, and 3) were compared to general fertility recommendations (Havlin et al., 2005 Tables 9-13, 9-14, and 9-16). Boxlu'um had average concentrations of 13.9, 143.8, 1.3, 16.6, and 18.6 $\mathrm{mg} / \mathrm{kg}$ for $\mathrm{P}, \mathrm{K}, \mathrm{Zn}, \mathrm{Mn}$, and Fe, respectively, and these nutrients were considered sufficient. Average concentrations of $0.6 \mathrm{mg} / \mathrm{kg}$ for Cu were marginal. Saklu'um had average concentrations of $0.7,6.8$, and $33.6 \mathrm{mg} / \mathrm{kg}$ for $\mathrm{Cu}, \mathrm{Mn}$, and Fe respectively, and these nutrients were considered sufficient. Average concentrations of 11.1, 117.7, and $0.8 \mathrm{mg} / \mathrm{kg}$ for $\mathrm{P}, \mathrm{K}$, and $\mathrm{Zn}$, respectively, were marginal. Kancab had average concentrations of $0.7,24.2$, and $11.4 \mathrm{mg} / \mathrm{kg}$ for $\mathrm{Cu}, \mathrm{Mn}$, and $\mathrm{Fe}$, respectively, and these 
nutrients were considered sufficient. Average concentrations of 0.8 and $84.5 \mathrm{mg} / \mathrm{kg}$ for $\mathrm{Zn}$ and $\mathrm{K}$, respectively, were marginal and average concentrations of $6.4 \mathrm{mg} / \mathrm{kg}$ for $\mathrm{P}$ were deficient. The fertility of these soils is similar to the results presented in Beach (1998).

Although several macro and micronutrients were greater in boxlu'um and saklu'um than kancab, concentration doesn't account for quantity. Kancab of the area were on average $50 \%$ deeper than the other two soil types (Table 1) and therefore could potentially provide more plant nutrients. The effective root zone is critical for soil fertility. Under typical circumstances a maize root system will grow laterally $1 \mathrm{~m}$ in all directions and will penetrate the soil to depths of $2 \mathrm{~m}$ (Feldman, 1994).

Each Mayan soil class was evaluated with the land capability classification system developed by the USDA (Klingebiel and Montgomery, 1961). Kancab was in class III with severe limitations that reduce the choice of crops or require special cultural practices. The limitations included shallow depths to bedrock and low fertility that are not easily corrected. These class III soils should be amended with OM and they should not be worked when wet. Boxlu'um was in class IV with has very severe limitations that restrict the choice of crops and require very careful management. The limitations included shallow soils, low moisture-holding capacity, and salinity. Class IV soils in subhumid and semiarid areas may produce adequate yields during years of above average rainfall; low yields during average rainfall; and failures during years of below average rainfall. Fruit and ornamental trees and shrubs may be suitable for some class IV soils. Saklu'um soils were in class V with little to no erosion hazard but their use is limited it to 
rangeland, woodland, wildlife and water shed. Some limitations included ponded areas and nearly level stony soils.

We observed that boxlu'um was associated with ancient settlement and the soil in both rural and urban settlements of Chunchucmil contrasted with the boxlu'um from the surrounding area. Even in areas of boxlu'um of the tzekel, the boxlu'um within settlement structures differed in soil structure and color from the boxlu'um outside settlement. The boxlu'um on the house mounds and platforms developed after abandonment and would not have been considered of agricultural importance in ancient times. We hypothesized that there were differences in parent materials, elevated concentrations of soil nutrients, and a changes in soil physical properties within settlement and that the intensity of contrast from the surrounding soil varied depending on duration and density of occupation.

Boxlu'um from occupied (boxlu'um-o) and unoccupied (boxlu'um-u) areas were separated by proximity to ancient structures and then compared. Many of the physical and chemical properties of both boxlu'um-o and boxlu'um-u were significantly different $(P<0.05)$ (Table 4). Boxlu'um-o had greater values than boxlu'um-u for $\mathrm{CaCO}_{3}$ equivalent, $\mathrm{BC}, \mathrm{Cu}, \mathrm{Mn}$, and $\mathrm{Zn}$ and was strongly effervescent, whereas boxlu'um-u had greater levels of total $\mathrm{N}$, total $\mathrm{OC}, \mathrm{P}, \mathrm{EC}$, and $\mathrm{Na}$ and was very slightly effervescent. The very fine granular aggregates were hydrophobic and would not wet and disperse. Hydrophobicity was observed in $45 \%$ of boxlu'um-u profiles and in $8 \%$ in boxlu'um-o profiles. The hydrophobic boxlu'um-o is explained by the fact that these soils were near structures on the edge of the rural site of Pocholchen, which was surrounded by hydrophobic boxlu'um-u. Hydrophobic or water repellent soils have negligible water 
holding capacity and are generally infertile. Water repellent soils are seasonal. During the rainy season the hydrophobicity eventually can disappear, but if the soil is given time to dry out, the hydrophobicity can return (Quyum, 2000). This is problematic for Northwest Yucatán since rain is variable and there exists a dry period in the middle of the rainy season.

It is thought that water repellency occurs because hydrophobic organic matter (OM) covers soil particles (Quyum, 2000). Other factors that are associated with hydrophobicity are fungal growth, soil microorganisms, and plant type (Quyum, 2000), but the existence of hydrophobicity in Northwest Yucatán has not yet been studied.

The greater values in boxlu'um-o of $\mathrm{CaCO}_{3}$ equivalent $(24 \%), \mathrm{BC}(0.9 \mathrm{~g} \mathrm{BC} / \mathrm{kg}$ soil) and soil organic carbon (SOC) (1.0\% BC of SOC), $\mathrm{Cu}(0.8 \mathrm{mg} / \mathrm{kg}), \mathrm{Mn}(20 \mathrm{mg} / \mathrm{kg})$, and $\mathrm{Zn}(1.7 \mathrm{mg} / \mathrm{kg})$ (Table 4) were 154, 43, 225, 2,392, 146, and 588\% greater than boxlu'um-u and could be explained by ancient human activities. Higher $\mathrm{CaCO}_{3}$ equivalent resulted from the broken-up building materials and stucco. Greater BC concentrations, or charcoal, come from the creation of stucco, and from ancient household cooking activities. The high concentrations of $\mathrm{Cu}$ and $\mathrm{Mn}$ have been associated with organic refuse and craft production (Parnell et al., 2002) and the source of these elements could have also accumulated from the imported building materials.

Boxlu'um-u had nearly $100 \%$ more exchangeable $\mathrm{Na}(17.4 \mathrm{mg} / \mathrm{kg})$, total OC (23.2\%), total $\mathrm{N}(1.8 \%)$, and $\mathrm{P}(22.9 \mathrm{mg} / \mathrm{kg})$ and $50 \%$ higher $\mathrm{EC}(1.5 \mathrm{dS} / \mathrm{m})$ than boxlu'um-o. The greater values of total $\mathrm{N}$, total $\mathrm{OC}$, and $\mathrm{P}$ in boxlu'um-u are explained by interactions of soil chemical and physical properties. In general, the increased concentrations of both $\mathrm{P}$ and $\mathrm{N}$ in the soils were significantly related to increased levels 
of OC $(P<0.05)$. Retention of OC is often attributed to clay content, base saturation, the chemistry of the SOM, and microbial activity rates (Oades, 1988).

Higher EC and $\mathrm{Na}$ in boxlu'um-u can be explained by depth to water table.

Pocholchen is in the tzekel zone, and in the encompassing area of boxlu'um-u the water table was visible in fractures of the bedrock at depths of approximately 10 to $15 \mathrm{~cm}$ from the soil surface. Close proximity allows wicking of groundwater and deposition of salts. The water table was not visible in the site of Pocholchen. Soil profiles revealed fill for ancient patio groups which increased depth to water table. Average soil profile depth at Pocholchen for boxlu'um-u was $6 \mathrm{~cm}$ and for boxlu'um-o $12 \mathrm{~cm}$.

Boxlu'um-o, boxlu'um-u, kancab, and saklu'um were subjected to the WDPT test, which rates the repellency of the soil. Boxlu'um-o (1 s), kancab (0 s), and saklu'um (1 s) were wettable and nonwater repellent. Boxlu'um-u was extremely water repellent and the water droplet took $39 \mathrm{~min}$ to penetrate.

Boxlu'um-o is an anthropogenic soil found within settlement and didn't exist to the extent that it is today during ancient Maya occupation (Dahlin et al., 2005). The more favorable properties of boxlu'um-o wouldn't have contributed to the agricultural resources. Boxlu'um-o soil profiles weren't included in the land evaluation.

We can estimate the rate of soil formation for Chunchucmil since the site's decline in A.D. 800-900 (Dahlin, 2003). We choose two profiles on ancient patio structures in locations that were unlikely to have been used for modern cultivation and had dense fill that decreased erosion. Soil accumulation above a large platform floor at profile NA4 (Nah Caña) and soil above a patio floor at profile NT12 at Chunchucmil were 6 and $11 \mathrm{~cm}$ deep, respectively. We estimate that soils formed in Nah Caña and 
Chunchucmil during 1,100 years of abandonment at a rate of $0.05 \mathrm{~mm} \mathrm{yr}^{-1}$ and $0.10 \mathrm{~mm}$ $\mathrm{yr}^{-1}$. Similar to Chunchucmil, Fernandez et al. (2005) estimated soil formation rates of $0.087 \mathrm{~mm} \mathrm{yr}^{-1}$ to $0.096 \mathrm{~mm} \mathrm{yr}^{-1}$ at Piedras Negras, Guatemala.

Rural Settlement

Land settlement patterns can illustrate preferences of agricultural resources (Fedick, 1995). Based on the vegetation map (Figure 3), we could predict to which potential Mayan soil class each site pertained. The majority of secondary sites, 21 of 24, were in kancab, 2 were in boxlu'um, and 1 was in saklu'um. Tertiary sites exhibited a similar pattern with 11 sites in kancab, 2 in boxlu'um, and 3 in saklu'um. The location of the majority of the rural sites was centered in the karst plain with kancab

If we assume the major occupation for the rural population was agriculture and settlement location was in close proximity to milpas, then the ancient Maya preferred cultivating in kancab north and east of Chunchucmil. The soil east of Chunchucmil is deeper, has a slightly better capability class, and is laterally more continuous than the savanna or tzekel.

The sparse ancient settlement in the tzekel and swamp/estuary with their shallow soils confirmed that these areas were not preferred for cultivation; rather, the tzekel zone may have been reserved for wood and other forest products and for hunting. It would have been better economically to utilize the tzekel zone for certain useful species, like agave, nopal, and fruit trees, that do not require deep soils (Hutson et al., 2007). Nearly all secondary and tertiary sites in the savanna were located on the edge of the tzekel 
(Figure 3). These sites would have been ideally situated between arable land to the east and forest products to the west

Rural settlement and land use is an issue of interest for many geographers (Chisholm, 1971). Research from all over the world of prehistoric and historic land use has shown that agricultural activity is usually concentrated within a $1-2 \mathrm{~km}$ radius from settlement and beyond that, activities decline with distance and often terminate at around $5 \mathrm{~km}$ (Stone, 1991). Modern Maya milperos follow a similar trend and generally choose locations for cultivation based on location, soil type, and distance to milpa (Reina, 1967). To minimize movement costs, these milperos live near their milpas and arrange them so that he spends no more than an hour on the trail traveling between each milpa to minimize movement costs (Reina, 1967). With a radius of $5 \mathrm{~km}$, the area of cultivable land surrounding all known ancient settlement in the savanna and karst plain at Chunchucmil would be $445 \mathrm{~km}^{2}$, much lower than the proposed sustaining area of 600 $\mathrm{km}^{2}$ by Beach (1998). At optimum crop yields and shortest fallow, this area would only sustain 22,250 persons using Conklin's (1957) equation. For the $+42,400$ Maya in the core area of ancient Chunchucmil, the land requirement using the highest crop yields for this region and lowest fallow cycle would have been $848 \mathrm{~km}^{2}$. This estimate does not include areas with no soil cover, which would raise the estimate to over $1,000 \mathrm{~km}^{2}$. The enormous land requirement for just the core area means that a milpero would have been required to walk as much as $25 \mathrm{~km}$ from Chunchucmil if agriculture solely took place in the savanna and karst plain. Even without suburban and rural population estimates, it is improbable that the ancient Maya traveled this great distance to cultivate. Known rural settlement only extended as much as $13 \mathrm{~km}$ away from Chunchucmil. 


\section{Carbon Isotopes}

Carbon isotopic ratios $\left({ }^{13} \mathrm{C} /{ }^{12} \mathrm{C}\right)$ were analyzed to delineate probable areas of ancient agriculture. Ancient long-term maize cultivation leaves a distinct isotopic signature in the soil organic matter (Wright, 2006; Burnett, ND; Fernández, 2005). Analysis of soil profile yielded a variety of $\delta^{13} \mathrm{C}$ values. The $\delta^{13} \mathrm{C}$ values varied little within each soil profile (see Appendix). The greatest shift from $\delta^{13} \mathrm{C}$ of surface to depth was $-2.4 \%$ and the median shift was $\pm 0.27 \%$.

The $\delta^{13} \mathrm{C}$ values of surface horizons varied significantly according to soil type and vegetative zone $(P=0.00)$. Nearest the ocean is the swamp/estuary zone with highly organic soil profiles. These soils had average $\delta^{13} \mathrm{C}$ values of $-27.18 \%$, which indicates that this zone is dominated by $\mathrm{C}_{3}$ vegetation. East of the swamp/estuary zone are the tzekel hillocks, which had average $\delta^{13} \mathrm{C}$ values of $-25.44 \%$. This zone has mainly a high canopy with few grasses but enough $\mathrm{C}_{4}$ vegetation to shift slightly from $\mathrm{C}_{3}$. A small ancient rural site called Bon with deep boxlu'um soils in the savanna had average values of $-23.67 \%$. Surface horizons of kancab in the karst plain and savanna were analyzed and had average values of $-22.39 \%$. The decrease in discrimination of the ${ }^{13} \mathrm{C}$ isotope across Chunchucmil's landscape from west to east follows the change in vegetative zones and is as indication of $\mathrm{C}_{4}$ vegetation distribution.

Surface horizons from within structure groups of central Chunchucmil were collected and $\delta^{13} \mathrm{C}$ values were compared to control samples from 4 to $6 \mathrm{~km}$ north of Chunchucmil. Buried surface horizons beneath ancient structures were also sampled. 
Surface soils from structure groups in central Chunchucmil had average $\delta^{13} \mathrm{C}$ values of $23.50 \%$, similar to that of boxlu'um, and control samples had average $\delta^{13} \mathrm{C}$ values of $22.59 \%$, similar to that of kancab soils. The buried A horizons under Classic structures had average $\delta^{13} \mathrm{C}$ values of $-24.00 \%$. Statistically there were no differences between surface soils from structure groups, buried A horizons, and control samples $(P=0.90)$.

Of six grasses collected in the Chunchucmil region, four were $\mathrm{C}_{4}$ and two were $\mathrm{C}_{3}$. This long-term mix of native $\mathrm{C}_{4}$ vegetation prevents us from using stable carbon isotopes to delineate zones of ancient maize agriculture in the savanna and karst plain of the Northwest Yucatán. The mixed $\mathrm{C}_{3} / \mathrm{C}_{4}$ vegetation produced humin with a $\delta^{13} \mathrm{C}$ values similar to values in soil horizons of suspected ancient maize growth in a predominately $\mathrm{C}_{3}$ vegetative region. In the shallow soils of Northwest Yucatán, it would be impossible to differentiate between ancient milpas and native vegetation. Soil depth complicates the situation further because of a high rate of bioturbation and the inability to observe a change with depth. Soil samples are usually taken every $10 \mathrm{~cm}$ for the maize signature method; however, average profile depths for boxlu'um, kancab, and saklu'um were 12, 21 , and $10 \mathrm{~cm}$. However, even with the shallow soil of the tzekel, if long-term maize cultivation took place, then we would assume that average $\delta^{13} \mathrm{C}$ values would be similar to those of the savanna and karst plain. Instead, the $\delta^{13} \mathrm{C}$ values suggest that maize was either scarcely or never grown in the tzekel.

The swamp/estuary soils would not be excluded from the ${ }^{13} \mathrm{C}$ maize signature method because of the predominant $C_{3}$ vegetation and greater soil depth, but salinity (14 $\mathrm{dS} / \mathrm{m})$ (Beach, 1998) and seasonal inundation make them highly improbable for ancient cultivation. 
Black Carbon

Black carbon, a product of incomplete combustion (Brodowski et al., 2005), is almost entirely made up of aromatic C (Schmidt and Noack, 2000) that resists chemical and microbial decomposition and persists through geological time-scales (Taylor et al., 1998; Glaser and Amelung, 2003; Glaser et al., 2001a; Dai et al., 2005). The accumulation of $\mathrm{BC}$ is related to climate, textural properties, concentration of SOM, and soil moisture (Glaser and Amelung, 2003). Soil fertility is enhanced by BC because of increased the soil nutrient holding capacity (Glaser and Amelung, 2003; Glaser et al., 2001a) which has greatly improved crop yields on the infertile soils of the Amazon basin (Glaser et al., 2001a).

There is no doubt that charcoal was produced by the Maya, but the basic question is what was done with it. Some possibilities are:

1. The Maya collected the charcoal and transported it to their milpas,

2. The Maya deposited the charcoal in their home gardens,

3. The Maya did not do anything except discard it as waste.

Some of these possibilities were tested by observing BC with respect to distance from settlement. If long-term soil amending occurred in milpas, we should observe elevated concentrations in unoccupied areas. Soil profiles were categorized as off-mound (no ancient structures within $\sim 20 \mathrm{~m}$ ), near-mound (within $20 \mathrm{~m}$ of ancient structures), and onmound. Each category was given a numerical value and compared to $\mathrm{BC}$ concentrations. Soil profiles from rural sites of Ikmil, Pocholchen, and Nah Caña were analyzed. 
A transect that was centered over the site center of Ikmil, a large secondary site, and reached to the unoccupied areas west and east of the site. A regression analysis of position versus $\mathrm{BC}$ concentrations shows that there is a significant correlation with proximity to ancient structures $\left(P=0.00, \mathrm{R}^{2}=0.59\right)$. Black carbon concentrations increased from off-mound ( $0.62 \mathrm{~g} \mathrm{BC} / \mathrm{kg}$ soil), to near-mound ( $0.78 \mathrm{~g} \mathrm{BC} / \mathrm{kg}$ soil), and then to on-mound (1.1 g BC/ kg soil). BC concentrations also increased from off-mound $(0.61 \mathrm{~g} \mathrm{BC} / \mathrm{kg}$ soil $)$ to near-mound $(0.90 \mathrm{~g} \mathrm{BC} / \mathrm{kg}$ soil $)$ in Pocholchen $\left(P=0.01, \mathrm{R}^{2}=\right.$ $0.45)$.

The higher concentrations of $\mathrm{BC}$ on and near house mounds versus off-mound suggest an incidental effect of ancient human activities. Cooking fires and charcoal incidental to the burning of old thatch and to stucco production may have been major sources of $\mathrm{BC}$ in near mound and on mound soils. The $\mathrm{BC}$ concentrations were mapped for Ikmil in Figure 6 and the higher concentration of BC was outlined both the site and some ancient structures sampled.

The $\mathrm{BC}$ concentrations surrounding Chunchucmil, 0.37-1.37 g BC/ kg soil, were an order of a magnitude or more lower in the surface horizon compared to the terra preta soils of the Brazilian Amazon region, $\sim 11 \mathrm{~g} \mathrm{BC} / \mathrm{kg}$ soil, using the same digestion method (Glaser et al., 2001b). Even the BC concentrations of the control samples surrounding the terra preta soils were approximately twice as high as $\mathrm{BC}$ concentrations at Chunchucmil.

In comparison of the three Mayan soil classes, we hypothesized that the boxlu'um would have higher $\mathrm{BC}$ concentrations ( $\mathrm{g} \mathrm{BC} / \mathrm{kg}$ soil) than kancab and saklu'um because of its higher nutrient status and darker color, similar to the dark anthropogenic terra preta 
soils of the Amazon (McCann et al., 2001). However, there existed no significant difference between boxlu'um ( $0.7 \mathrm{~g} \mathrm{BC} / \mathrm{kg}$ soil), kancab ( $0.5 \mathrm{~g} \mathrm{BC} / \mathrm{kg}$ soil), and saklu'um $(0.6 \mathrm{~g} \mathrm{BC} / \mathrm{kg}$ soil $)$ soils $(P=0.47)$. The even distribution of $\mathrm{BC}$ throughout unoccupied rural Chunchucmil suggests that the major source of natural $\mathrm{BC}$ has been the occasional wildfires.

The source of the dark color of boxlu'um is likely related to the retention of SOM rather than to BC. Average total OC for boxlu'um, saklu'um, and kancab were 15.1, 8.8, and $6.4 \%$, respectively. Of the soil properties analyzed, it was found that as the exchangeable multivalent cations, $\mathrm{Ca}$ and $\operatorname{Mg}\left(P=0.00, \mathrm{R}^{2}=0.55\right)$, and clay content $(P=$ $\left.0.00, \mathrm{R}^{2}=0.44\right)$ increased, SOM also increased. One mechanism of organic matter retention is cation bridging between clays and organic colloids (Oades, 1988). The accumulation of SOM through introduced multivalent cations may explain the black soil islands of anciently occupied areas among the reddish brown soils of the savanna and karst plain. The dissolution of broken up limestone from the construction of patio groups, the stucco used by the ancient Maya, and the lime used for food preparation were the major sources for elevated $\mathrm{Ca}$ and $\mathrm{Mg}$ (Fernández et al., 2002). The long term liming effects of the stucco and other construction materials has apparently enhances the accumulation of OM of house mound soils (Oades, 1988).

Black carbon is often reported as a proportion of SOC, which helps describe factors of BC accumulation (Dia et al., 2005). Terra preta soils of Amazonia are reported to have up 35\% BC as a portion of the SOC (Glaser et al., 2001a). In contrast, boxlu'um, kancab, and saklu'um had much lower values of $0.71,2.35$, and $0.57 \%$ BC of SOC, respectively, but were significantly different between each soil class $(P=0.00)$. We 
observed in the field that kancab generally had greater soil moisture than saklu'um and boxlu'um during the dry season. Clay content was also greatest in kancab. These two factors tend to play a role in BC accumulation (Glaser and Amelung, 2003). These three soils represent three very different vegetative zones.

Phosphorus Concentrations and Biomarkers

Chemical residues, stanol biomarkers and $\mathrm{P}$, were analyzed to determine if night soiling occurred in the Chunchucmil region. An enrichment of both properties should appear in areas of ancient croplands if amended with fecal residues (Fernández et al., 2002). Hutson et al. (2007) reported the results of the stanol biomarkers for night soiling in a study on selected house lots of Chunchucmil. Coprostanol is formed in the intestinal tract of most higher mammals, and has considerable potential as an indicator of ancient manuring and night soiling (Bull et al., 1999). The only soil sample that tested positive for Coprostanols was a control sample from modern house lot at Chunchucmil. None was found in any of the archaeological samples. We should have found traces of coprostanols if copious amounts of fecal matter were applied; however, it is likely that the coprostanols from ancient occupation decomposed in the warm, seasonally wet environment of Northwest Yucatán.

The isopleth map of soil P revealed that P concentrations correlated with the change in vegetation and with densely populated regions. There existed no anomalies of elevated P above normal background concentrations in potential outfield areas. Soil P concentrations were naturally elevated in the swamp/estuary $(9.3-14 \mathrm{mg} / \mathrm{kg})$ and tzekel 
$(14.1-22.3 \mathrm{mg} / \mathrm{kg})$ and then declined in the savanna $(5.7-6.4 \mathrm{mg} / \mathrm{kg})$ and karst plain (6.5$7.2 \mathrm{mg} / \mathrm{kg}$ ). Of the 104 soil profiles collected, the range of soil P was $2-46 \mathrm{mg} / \mathrm{kg}$; average values for each Mayan soil class for $\mathrm{P}$ are in Tables 1, 2, and 3. Soil P concentrations found in middens and suspected marketplaces in central Chunchucmil reached concentrations upwards of $250 \mathrm{mg} / \mathrm{kg}$ (Dahlin et al., 2007). There is no evidence of increased accumulation of $\mathrm{P}$ above background levels that would suggest the ancient Maya performed night soiling.

Geostatistical Analyses

Dense settlement of ancient Chunchucmil left an imprint of both physical and chemical properties. This is most notable when observing selected soil properties mapped over part of Chunchucmil's sustaining area $\left(52 \mathrm{~km}^{2}\right)$ using geospatial analysis in ArcMap $^{\circledR}$. Soil P and K (Olsen method), trace elements, Cu, Mn, Zn, and Fe (DTPA method), exchangeable ions, $\mathrm{Ca}, \mathrm{Mg}, \mathrm{Na}$, and $\mathrm{K}$, and several other physical and chemical soil properties were explored as possible indicators of human activity in occupied areas and land usage in unoccupied areas. Soil K was analyzed with two separate methods (Olsen and DTPA extractable) for comparison of their effectiveness to indicate ancient activity.

The spatial distribution of soil P, K (Olsen), OC (Figure 7), and Mg were similar. Concentrations of soil $\mathrm{P}, \mathrm{K}$ (Olsen), OC, and $\mathrm{Mg}$ were naturally elevated in the tzekel and swamp/estuary $(9.3-22.3 \mathrm{mg} / \mathrm{kg}, 127-262 \mathrm{mg} / \mathrm{kg}, 9.5-17.9 \%$, and $30-63 \mathrm{mg} / \mathrm{kg}$, respectively) and then they declined in the savanna and karst plain $(5.7-7.2 \mathrm{mg} / \mathrm{kg}, 73$ - 
$115 \mathrm{mg} / \mathrm{kg}, 5.6-8.3 \%$, and $17-25 \mathrm{mg} / \mathrm{kg}$, respectively). Urban Chunchucmil was outlined by each soil property and intensity increased toward the center of the site. The elevated island of P, K (Olsen), OC, and Mg (7.3-9.2 mg/kg, 116-262 mg/kg, 8.4-13.0\%, and 26$63 \mathrm{mg} / \mathrm{kg}$, respectively) was not exactly centered over Chunchucmil, but we are confident that an addition of a southwestern transect would rectify the positioning.

Exchangeable Ca (Figure 8) was elevated in Chunchucmil, greater than 561 $\mathrm{mg} / \mathrm{kg}$, and background concentrations decreased gradually from east to west, $538 \mathrm{mg} / \mathrm{kg}$ in the karst plain to $489 \mathrm{mg} / \mathrm{kg}$ in the swamp/estuary. Conversely, percent $\mathrm{CaCO}_{3}$ equivalent decreased from west to east, greater than $40 \%$ in the swamp/estuary to $4-11 \%$ in the karst plain. Ikmil and Chunchucmil were slightly elevated in $\mathrm{CaCO}_{3}$ equivalent, but the contrast from background levels is not as pronounced as exchangeable $\mathrm{Ca}$.

The reasons for elevated concentrations of $\mathrm{P}, \mathrm{K}$ (Olsen), $\mathrm{OC}, \mathrm{Mg}$, and $\mathrm{Ca}$ in central Chunchucmil are multifarious. Soil P and $\mathrm{K}$ initially accumulated after centuries of discarded food and waste. Increased SOM, likely caused by increased polyvalent cations from broken-up limestone and stucco, stimulated the retention of additional $\mathrm{P}$ and $\mathrm{K}$.

Exchangeable K (DTPA) gradually increased from west $(13.4 \mathrm{mg} / \mathrm{kg})$ to east $(31.9 \mathrm{mg} / \mathrm{kg})$ and did not share the same patterns as K (Olsen). Fernández et al. (2002) used exchangeable $\mathrm{K}$ in soils from a modern Maya house lot and discovered that exchangeable $\mathrm{K}$ was elevated in food preparation areas beneath a thatched roof. From an abandoned house lot with three years of exposure to weather, exchangeable $\mathrm{K}$ was slowly leached and concentrations were only slightly elevated above background levels. Now over a thousand years of abandonment, ancient human activity cannot be observed with 
exchangeable $\mathrm{K}$ at Chunchucmil. Ancient human activity is illegible with DTPA extractable $\mathrm{K}$ but $\mathrm{K}$ (Olsen) may be a more efficient indicator of ancient human activity within settlement for this area.

The isopleth maps of extractable $\mathrm{Fe}$ and $\mathrm{Cu}$ did not follow vegetation change as well as other soil properties because of high variability. Even with the greater variation, some patterns could be observed. In general, there were elevated concentrations of both $\mathrm{Fe}$ and $\mathrm{Cu}$ in the swamp/estuary (40-52 and $1.0-1.7 \mathrm{mg} / \mathrm{kg}$, respectively) and mildly elevated in central Chunchucmil (23-34 and $0.7-1.7 \mathrm{mg} / \mathrm{kg}$, respectively) and background concentrations were (11-23 and $0.4-0.7 \mathrm{mg} / \mathrm{kg}$, respectively).

Soil $\mathrm{Na}$ decreased from west to east with concentrations found in the savanna extending slightly into the karst plain north of Chunchucmil. The change of $\mathrm{Na}$ could be explained by depth to water table rather than by human activity. Depth to groundwater increased in an ESE direction with slight extension above where ancient Chunchucmil is located (Luzzadder-Beach, 2000).

Soil concentrations of DTPA extractable Zn exhibited a peculiar pattern. Concentration gradients were high in the swamp/estuary zone $(1.1-2.9 \mathrm{mg} / \mathrm{kg})$ and low $(0.4-0.9 \mathrm{mg} / \mathrm{kg})$ in the tzekel, savanna, and karst plain except for two locations. Concentrations were high, 1.1-2.9 mg/kg, in between Ikmil and Chunchucmil and on the northeast periphery of Chunchucmil. Soil concentrations of Mn were relatively even throughout the mapped region, between 7 and $19 \mathrm{mg} / \mathrm{kg}$, except northeast of Chunchucmil, where concentrations rise sharply to 31 to $44 \mathrm{mg} / \mathrm{kg}$. The source of $\mathrm{Zn}$ and $\mathrm{Mn}$ is unknown, and although $\mathrm{Mn}$ and $\mathrm{Zn}$ have been connected with ancient human 
activity (Linderholm and Lundberg, 1994), it is likely the anomalies are caused by inconsistencies in parent material and/or an increased CEC.

Percent clay was lower in the swamp/estuary and tzekel (25-30\%) and was slightly higher in the savanna and karst plain (32-34\%). There was an irregular elevated pattern of clay content in the karst plain (34-36\%) and the pattern appeared to slightly overlap Zn. Greater clay content increases CEC and may have attributed to the greater $\mathrm{Zn}$ in the two adjacent areas of Chunchucmil; however, for the karst plain, $\mathrm{Zn}$ concentrations did not increase with increasing clay content $\left(P=0.83, \mathrm{R}^{2}=0.00\right)$.

Soil $\mathrm{pH}$ gradually decreased from west to east. In the swamp/estuary and tzekel the $\mathrm{pH}$ was slightly alkaline and in the karst plain the $\mathrm{pH}$ was neutral.

Soil profile depth (Figure 9) generally increased from west $(6 \mathrm{~cm})$ to east $(29 \mathrm{~cm})$ except at ancient Chunchucmil. Reconnaissance was consistent with the isopleth map of profile depth, thin boxlu'um $(0-19 \mathrm{~cm})$ in central Chunchucmil surrounded by deeper kancab $(+29 \mathrm{~cm})$. In Hutson et al. (2007), patio groups were described as devoid of most soil beyond the structural core. Much of this area matches the depth of soil that would have formed at the calculated soil formation rate after abandonment. This implies that central Chunchucmil was likely denuded of most of its soil cover. The denseness of structures and lack of soil likely limited central Chunchucmil to small home gardens, except for certain fruit trees that survive adequately in sparse soils (Hutson et al., 2007) 


\section{CONCLUSION}

An assessment of the agricultural resources surrounding Chunchucmil has led us to believe that the development of this ancient Maya site wasn't based on the available agricultural resources. Poor building materials, shallow rocky soils, low fertility, variable rains, seasonal inundation, and water repellent soils would nave precluded a large population. Historic agricultural yields using traditional methods could not have supported the ancient population during Chunchucmil's major period of occupation. How, then, did the ancient Maya of Chunchucmil feed themselves? Solving this perplexing scenario has been the aim of this investigation.

Of the three dominant Mayan soil classes, kancab was found to be the consistently arable soil in Chunchucmil's sustaining area. Saklu'um had high salts, level stony soils, and ponding and is unsuitable for cultivation. Boxlu'um-u had greater concentrations of nutrients for crop growth than kancab, but the often hydrophobic OM, low soil moisture, and shallow depth negate the higher concentrations, especially when precipitation is low or variable. Besides the fact that kancab covers a greater region, kancab must have been agriculturally important for the ancient Maya because it provided some security with higher soil moisture, greater soil depth, and improved nutrient transportation. Modern milpas are scattered throughout the karst plain while the tzekel remains mostly uninhabited and uncultivated.

There can still be problems with farming kancab - mainly ponding that can hinder crop development (Beach, 1998). Where soil profiles were sufficiently excavated, 
bedrock was observed to have a greater frequency and size of fractures east of Chunchucmil. This may explain why most of the rural settlement is east of Chunchucmil.

Carbon isotopic signatures of ancient maize agriculture proved unsuccessful in delineating agricultural soils of the area surrounding Chunchucmil. Shallow soils and native vegetation of $\mathrm{C}_{4}$ and $\mathrm{C}_{3}$ plants mask the isotopic signature of maize.

The land-use capability of the karst plain with kancab was ranked as more favorable than all other vegetative zones and contained the majority of rural sites. The land capability is severely limited in the swamp/estuary and tzekel. The lack of rural settlement within these zones suggested that they were not used for cultivation; however, they may have remained a wooded area and provided Chunchucmil with vital raw materials.

There was no evidence of agricultural intensification of Chunchucmil soils by night soiling and soil amendments with charcoal. Apparently the stanol biomarkers decomposed quickly in the warm, seasonally wet environment and the biomarkers were not observed in the Chunchucmil samples. Soil P concentrations in unoccupied areas didn't exhibit any patterns or concentrations that would be expected if long-term night soiling occurred. $\mathrm{BC}$ ( $\mathrm{g} \mathrm{BC} / \mathrm{kg}$ soil) level were low in comparison to the terra preta soils of Amazonia. Incidental elevated concentrations of $\mathrm{BC}$ were found on ancient structures and within settlement. Thus we can infer that the Maya of Chunchucmil did amend their soils with charcoal.

The distributions of soil physical and chemical properties were investigated in unoccupied areas to determine whether agricultural intensification could be observed. Intensive agriculture through soil amendments intuitively should have a buildup of 
chemical residues, but elevated levels of clay, $\mathrm{Zn}$, and $\mathrm{Mn}$ were the only anomalies found in unoccupied areas with kancab soil. They were likely caused by differences in parent material. The traditional method of shifting cultivation doesn't have inputs of any source and the distribution of soil physical and chemical properties should resemble those observed in Chunchucmil. Based on this, ancient Maya agricultural practices at Chunchucmil were likely based on shifting cultivation.

A "habitation effect/halo" (Bintliff et al., 1990) was observed around ancient Chunchucmil. BC, Ca, P, K (Olsen), Mg, OC, and profile depth correlated with ancient settlement and these soil properties have the potential to indicate ancient human activity in Northwest Yucatán. Soil is a complex matrix and elements are bound and retained at different rates with change in environment and soil properties. It is impossible to know how much of these elements were deposited by the ancient Maya and how much accumulated after abandonment because of increased OC.

The ancient Maya of Chunchucmil during the Middle Classic (A.D. 400-700) have yet to fully reveal their secrets of how they fed themselves. There is no evidence that the ancient habitants of Chunchucmil practiced anything but traditional methods. Atypical crops could have supplemented for maize but they would have been subjected to the same poor soil conditions and the same disasters (flooding, drought, etc.) that plague the Northwest Yucatán. Instead, Chunchucmil likely traded perishable goods from places like the nearby Puuc Hills (30 km) for marine and estuary products (such as salt, bird feathers, pelts, sharks' teeth, stingray spines, and ornamental shell), fish, game, and other products brought in through Punta Canbalam ( $27 \mathrm{~km}$ ), one of Mesoamerica's major maritime trade route (Dahlin et al., 1998). 


\section{LITERATURE CITED}

Balesdent, J.and M. Balabane. 1992. Maize root-derived soil organic carbon estimated by natural 13C abundance. Soil Biology and Biochemistry 24: 97-101.

Barrera-Bassols, N. and V.M. Toledo. 2005. Ethnoecology of the Yucatec Maya: Symbolism, knowledge and management of natural resources. Journal of Latin America 4:9-41.

Beach, T. 1998. Soil constraints on northwest Yucatan Mexico: pedoarchaeology and Maya subsistence at Chunchucmil. Geoarchaeology: An International Journal $13: 759-791$

Bintliff, J.L., C. Gaffney, A. Waters, B. Davis, and A. Snodgrass. 1990. Trace element accumulation in soils in and around ancient settlements in Greece. p. 159-172. In Man's role in the shaping of the eastern Mediterranean landscape, S. Bottema, G. Entijes-Nieborg, and W. van Zeist (ed.) Balkema, Rotterdam.

Boutton, T.W. 1996. Stable carbon isotope ratios of soil organic matter and their uses as indicators of vegetation and climate change. p. 47-82. In Mass Spectrometry of Soils, T.W. Boutton and S. Yamasaki (ed.) Marcel Dekker Inc. New York.

Boutton, T.W. 1991. Stable carbon isotope ratios of natural materials: II. Atmospheric, terrestrial, marine, and freshwater environments. p. 173-185. In Carbon Isotope Techniques, D.C. Coleman and B. Fry (ed.) Academic Press Inc., San Diego.

Brodowski, S., A. Rodionov, L. Haumaier, B. Glaser, and W. Amelung. 2005. Revised black carbon assessment using benzene polycarboxylic acids. Organic 
Geochemistry 36:1299-1310.

Bull, I.D., I.A. Simpson, P.F. Van Bergen, and R.P. Evershed. 1999. Muck n’ molecules: organic geochemical methods for detecting ancient manuring. Antiquity 73:86-96.

Buol, S. W., R. J. Southard, R. C. Graham, and P. A. McDaniel. 2003. Soil genesis and classification. $5^{\text {th }}$ ed. Ames, Iowa: Iowa State Press.

Burnett, Richard. ND. Soil resources at Ramonal, Guatemala. Brigham Young University, Provo, Utah, Provo.

Chisholm, Michael. 1979. Rural settlement and land use: an essay in location. $3^{\text {rd }}$ ed. London: Hutchinson University Library.

Cogwill, U.M. 1960. Soil fertility, population, and the ancient Maya. National Academy of Sciences 46:1009-1011.

Conklin, H.C. 1957. Population-land balance under systems of tropical forest agriculture. Proceedings of the Ninth Pacific Science Congress, Pacific Science Association $7: 63$.

Costa, M.L., D.C. Kern, A.H.E. Pinto, and J.R.T. Souza. 2004. The ceramic artifacts in archaeological black earth (terra preta) from Lower Amazon Region, Brazil: chemistry and geochemical evolution. Acta Amazonia 34:375-386.

Curtis, J.H., D.A. Hodell, and M. Brenner. 1996. Climate variability on the Yucatan Peninsula (Mexico) during the past 3500 years, and implications for Maya cultural evolution. Quaternary Research 46:37-47. 
Dahlin, B.H. 2003. Chunchucmil: A Complex Economy in NW Yucatan. Mexicon 25:129-138.

Dahlin, B.H. 1983. Climate and prehistory on the Yucatan Peninsula. Climatic Change 5: 245-263.

Dahlin, B.H., A.P. Andrews, T. Beach, Clara Bezanilla, Patrice Farrell, Sheryl Luzzadder-Beach, and Valerie McCormick. 1998. Punta Canbalam in context: A peripatetic coastal site in northwest Campeche, Mexico. Ancient Mesoamerica 9:1-15.

Dahlin, B.H., T. Beach, S. Luzzadder-Beach, D. Hixson, S. Hutson, A. Magnoni, E. Mansel, and D.E. Mazeau. 2005. Reconstructing agricultural self-sufficiency at Chunchucmil, Yucatan, Mexico. Ancient Mesoamerica 16:229-247.

Dahlin, B.H., C.T. Jensen, R.E. Terry, D.R. Wright, and T. Beach. 2007. In Search of an Ancient Maya Market. Latin American Antiquity In press.

Dai, X., T.W. Boutton, B. Glaser, R.J. Ansley, and W. Zech. 2005. Black carbon in a temperate mixed-grass savanna. Soil Biology \& Biochemistry 37, no. 1879-1881.

Dekker, L.W., S.H. Doerr, K. Oostindie, A.K. Ziogas, and C.J. Ritsema . 2001. Water repellency and critical soil water content in a dune sand. Soil Science Society of America Journal 65:1667-1674.

Drennan, R.D. 1984a. Long-distance movement of goods in the Mesoamerican formative and classic. American Antiquity 49:27-43. 
Drennan, R.D. 1984b. Long-distance transport costs in Pre-Hispanic Mesoamerica. American Anthropologist 86:105-112.

Dunning, N.P. and T. Beach. 2000. Stability and instability in pre-Hispanic Maya landscapes. p. 179-202. In Imperfect Balance, D. Lentz (ed.) Columbia University Press, New York.

Emerson, R.A. 1953. A preliminary survey of the milpa system of maize culture as practiced by the Maya Indians of the northern part of the Yucatan Peninsula. Annals of the Missouri Botanical Garden 40:51-62.

Eswaran, Hari, R. Almarez, E. van den Berg and P. Reich. 1997. An assessment of the soil resources of Africa in relation to productivity. Geoderma 77:1-18.

Fedick, S.L. 1995. Land evaluation and ancient Maya land use in the upper Belize River area, Belize, Central America. Latin American Antiquity 6:16-34.

Feldman, L. 1994. The maize root. p. 29-37. In The maize handbook, M. Freeling and V. Walbot (ed.) Springer, New York.

Fernández, F.G., K.D. Johnson, R.E. Terry, S. Nelson, and D. Webster. 2005. Soil Resources of the Ancient Maya at Piedras Negras, Guatemala. Soil Science Society of America Journal 69:2020-2032.

Fernández, F.G., R.E. Terry, T. Inomata, and M. Eberl. 2002. An ethnoarchaeological study of chemical residues in the floors and soil of Q'eqchi' Maya houses at Las Pozas, Guatemala. Geoarchaeology: An International Journal 17:487-519. 
Freeman, A., B. Chapman, and P. Siqueira. 2002. The JERS-1 Amazon Multi-season Mapping Study (JAMMS): science objectives and implications for future missions. International Journal of Remote Sensing 23:1447-1460.

Garza, S.T.d.G. and E. Kurjack. 1981. El Medio Ambiente y los Asentamientos Mayas en epoca Prehispanica. p. 17-28. In Memoria del Congreso Interno 1979,Centro Regional del Sureste, Instituto Nacional de Antropologia e Historia, Merida, Mexico.

Glaser, B. and W. Amelung. 2003. Pyrogenic carbon in native grassland soils along a climosequence in North America. Global Biogeochemical Cycles 17:1064.

Glaser, B., G. Guggenberger, and W. Zech. 2001a. Black carbon in sustainable soils of the Brazilian Amazon region. p. 359-364. In Understanding and managing organic matter in soils, sediments, and waters, R.S. Swift and K.M. Spark (ed.) International Humic Substances Society,

Glaser, B.H.L., G. Guggenberger, and W. Zech. 1998. Black carbon in soils: the use of benzenecarboxylic acids as specific markers. Organic Geochemistry 29:811-819.

Glaser, B., L. Haumaier, G. Guggenberger, and W. Zech. 2001b. The 'Terra Preta' phenomenon: a model for sustainable agriculture in the humid tropics. Naturwissenschaften 88:37-41.

Grube, N. 2000. Volcanoes and jungle - A richly varied habitat. In Maya: Divine Kings of the Rain Forest, N. Grube, E. Eggebrecht, and M. Seidel (ed.) Könemann, Cologne. 
Havlin, John, James D. Beaton, Samuel L. Tisdale, and Werner L. Nelson. 2005. Soil fertility and fertilizers: an introduction to nutrient management. $7^{\text {th }}$ ed. ed. New Jersey: Pearson Education, Inc.

Hester Jr., J.A. 1953. Agriculture, economy, and population densities of the Maya. Carnegie Institution of Washington Year Book 52:288-292.

Hixson, David. ND. Prehispanic settlement patterns and communication routes of the western Maya wetlands: an archaeological and remote sensing survey, Chunchucmil, Yucatan, Mexico. Tulane University, New Orleans.

Hixson, D. 2004. Preliminary Report of the 2002 Regional Settlement Pattern Survey. p. 16-23. In The Pakbeh Regional Economy Program: Report of the 2002 Field Season, B. Dahlin and D. Mazeau (ed.) Howard University, Washington D.C.

Hutson, S.R., T.W. Stanton, A. Magnoni, R. Terry, and J. Craner. 2007. Beyond the buildings: formation processes of ancient Maya houselots and methods for the study of non-architectural space. Journal of Anthropological Archaeology 26:442473.

Hutson, S.R. and R.E. Terry. 2006. Recovering social and cultural dynamics from plaster floors: chemical analyses at ancient Chunchucmil, Yucatan, Mexico. Journal of Archaeological Science 33:391-404.

Instituto Nacional de Estadística, Geografía e Informática. 1983. Carta de evapotranspiration y deficit de agua. Mexico City: Instituto Nacional de Estadística, Geografía e Informática. 
Johnson, Kristofer D., David R. Wright, and Richard E. Terry. 2007b. Application of carbon isotope analysis to ancient maize agriculture in the Petén region of Guatemala. Geoarchaeology: An International Journal 22:313-336.

JPL (Jet Propulsion Laboratory). 2008. Available from http://www.jpl.nasa.gov/releases/98/angkor98.html.

Kellman, M. and R. Tackaberry. 1997. Tropical Environments: the Functioning and Management of Tropical Ecosystems. New York: Routledge.

Killion, T.W. Residential ethnoarchaeology and ancient site structure: contemporary farming and prehistoric settlement agriculture at Matacapan, Veracruz, Mexico. Gardens of prehistory: the archaeology of settlement agriculture in greater Mesoamerica. p. 119-149 Tuscaloosa, The University of Alabama Press. 1992.

King, P.M. 1981. Comparison of methods for measuring severity of water repellence of sandy soils and assessment of some factors that affect its measurement. Australian Journal of Soil Research 19:275-285.

Linderholm, J. and E. Lundberg. 1994. Chemical characterization of various archaeological soil samples using main and trace elements determined by inductively coupled plasma atomic emission spectrometry. Journal of Archaeological Science 21:303-314.

Lou, Y., Y. Kim, and J. van Zyl. 1996. The NASA/JPL Airborne Synthetic Aperture Radar System. Summaries of the Sixth Annual Airborne Science Workshop, AIRSAR Workshop, Held 4-8 March, 1996. 2:51-56 Pasadena, CA, JPL. 
Lundell, C. L. 1934. Preliminary sketch of the phytogeography of the Yucatan Peninsula. Washington, D.C., Carnegie Institution of Washington Publication 436.

Luzzadder-Beach, S. 2000 . Water resources of the Chunchucmil Maya. Geographical Review 90:493-510.

Lynch, J. 1989. Distribution of overwintering nearctic migrants in the Yucatan Peninsula, I: general patterns of occurrence. The Condor 91:515-544.

Mann, C.C. 2002. The forgotten people of Amazonia. Science 297:921.

McCann, J.M., W.I. Woods, and D.W. Meyer. 2001. Organic matter and anthrosols in Amazonia: interpreting the Amerindian legacy. p. 180-189. In Sustainable Management of Soil Organic Matter, R.M. Rees, B.C. Ball, D.C. Campbell, and C.A. Watson (ed.) Sustainable Management of Soil Organic Matter. CAB International, Wallingford, UK.

Me-Bar, Y. and F. Valdez Jr. 2003. Droughts as random events in the Maya lowlands. Journal of Archaeological Science 30:1599-1606.

Oades, J.M. 1988. The retention of organic matter in soils. Biogeochemistry 5:35-70.

Parnell, J.J., R.E. Terry, and Z. Nelson. 2002. Soil chemical analysis applied as an interpretive tool for ancient human activities at Piedras Negras, Guatemala. Journal of Archaeological Science 29:379-404.

Pinstrup-Anderson, Per. 1994. World Food Trends and Future Food Security. 
Washington, D.C.: International Food Policy Research Institute.

Pope, K.O., J.M. Rey-Benayas, and J.F. Paris. 1994. Radar remote sensing of wetland and forest ecosystems in the Central American tropics. Remote Sensing of Environment 48:205-219.

Querejeta, J.I., H. Estrada-Medina, M.F. Allen, and J.J. Jiménez-Osornio. 2007. Water source partitioning among trees growing on shallow karst soils in a seasonally dry tropical climate. Oecologia 152:26-36.

Reina, R.E. 1967. Milpa and milperos: implications for prehistoric times. American Anthropologist 69:1-20.

Rico-Gray, V., J.G. Garci-Franco, A. Puch, and P. Sima. 1988. Composition and structure of a tropical dry forest in Yucatan, Mexico. International Journal of Ecology and Environmental Sciences 14:21-29.

Sanders, W.T. and D. Webster. 1988. The Mesoamerican Urban Tradition. American Anthropologist 90:521-546.

Schaefer, C.E.G.R., H.N. Lima, R.J. Gilkes, and J.W.V. Mello. 2004. Micromorphology and electron microprobe analysis of phosphorus and potassium of an Indian Black Earth (IBE) anthrosol from Western Amazonia. Australian Journal of Soil Research 42:401-409.

Schmidt, M.W.I. and Noack A.G. 2000. Black Carbon in soils and sediments: analysis, distribution, implications, and current challenges. Global Biogeochemistry Cycles 
14:777-793.

Sharer, R. J. 1994. The Ancient Maya. 5th edition ed. Palo Alto: Stanford University Press.

Shuman, M. 1974. The Town Where Luck Fell: The Economics of Life in a Henequen Zone Pueblo. The Town Where Luck Fell: The Economics of Life in a Henequen Zone Pueblo, Anthropology Department, Tulane University, New Orleans.

Soil Survey Staff. 2003. Keys to soil taxonomy. 9th ed. Blacksburg, VA: Pocahontas Press Inc.

Stone, G.D. 1991. Agricultural territories in a dispersed settlement system. Current Anthropology 32:343-353.

Taylor, G. H., M. Teichmuller, A. Davis, C. F. K. Diessel, R. Littke, and P. Robert. 1998. Organic Petrology. Stuttgart, Germany: Gebruder.

Van Wambeke, A. 1987. Soil moisture and temperature regimes of Central America, Carribean, and Mexico. Washington, D.C., Soil Management Support Services Technical Monograph No. 16. U.S. Department of Agriculture, Natural Resources Conservation Service.

Vlcek, D.T., S. Garza de González, and E.B. Kurjack. 1978. Contemporary farming and ancient Maya settlements: some disconcerting evidence. p. 211-223. In PreHispanic Maya Agriculture, P.D. Harrison and B.L. Turner II (ed.) University of New Mexico Press, Albuquerque. 
Webb, Elizabeth, Henry Schwarcz, Christopher T. Jensen, Richard E. Terry, Matthew D. Moriarty, and Kitty F. Emery. 2007. Stable carbon isotopes signature of ancient maize agriculture in the soils of Motul de San José, Guatemala. Geoarchaeology: An International Journal 22:291-312.

Webb, Elizabeth A., Henry P. Schwarcz, and Paul F. Healy. 2004. Carbon isotope evidence for ancient maize agriculture in the Maya lowlands. Journal of Archaeological Science 31:1039-1052.

Weisbach, C., H. Tiessen, and J.J. Jimenez-Osornio. 2002. Soil fertility during shifting cultivation in the tropical karst soils of Yucatan. Agronomie 22:253-263.

Wright, Dave R. 2006. Soil stable carbon isotope analysis of landscape features at Aguateca, Guatemala. Available from http://contentdm.lib.byu.edu/ETD/image/etd1206.pdf

Zech, W., P. Drechsel, and B. Neugebauer. 1991. Mineral deficiencies of forest trees in Yucatan (Mexico) and consequences for land-use. Turrialba 41:230-236. 


\section{FIGURES AND TABLES}

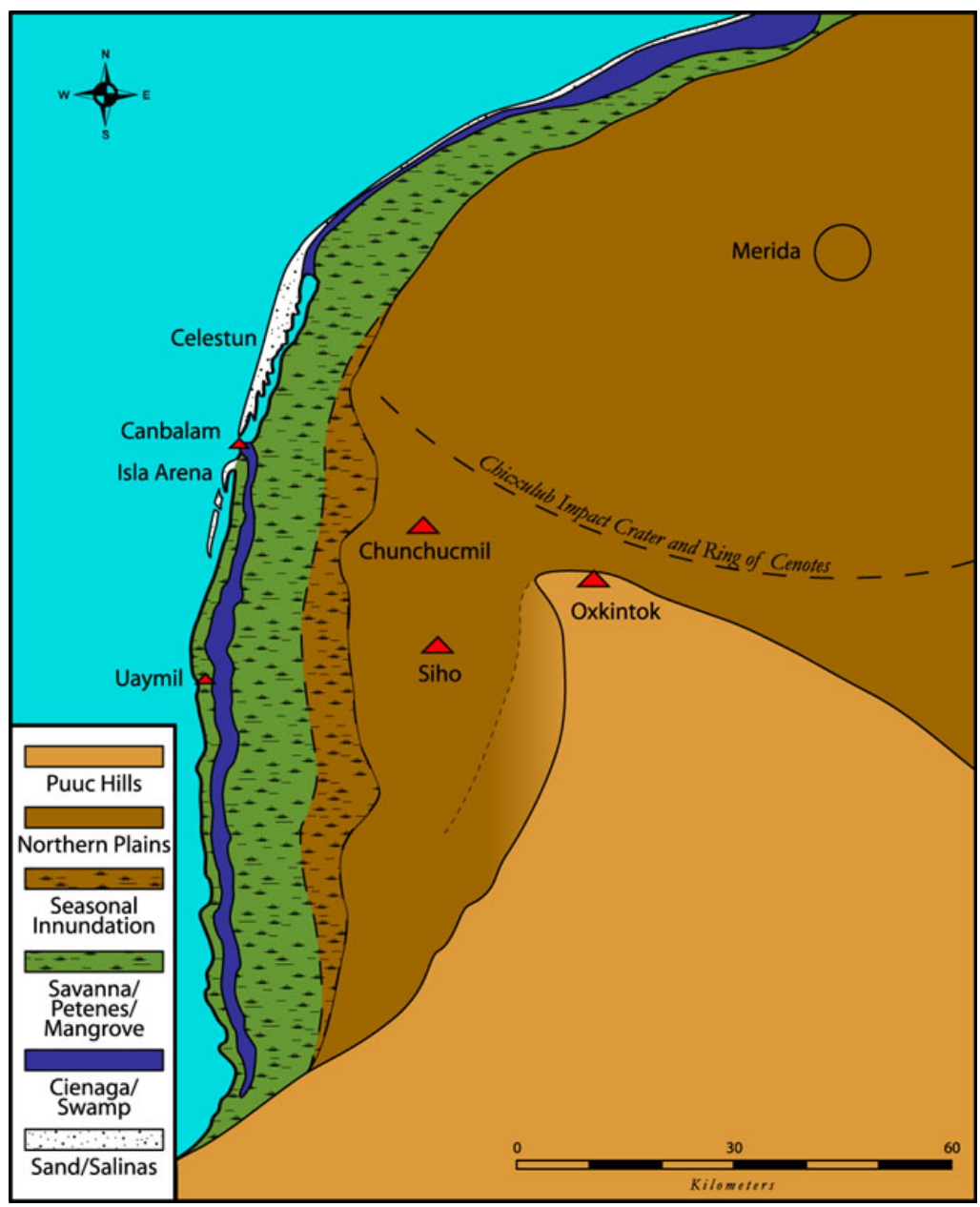

Figure 1. Map of ancient Maya cities and vegetative regions in the Northwest Yucatán (courtesy of Dave Hixson). 


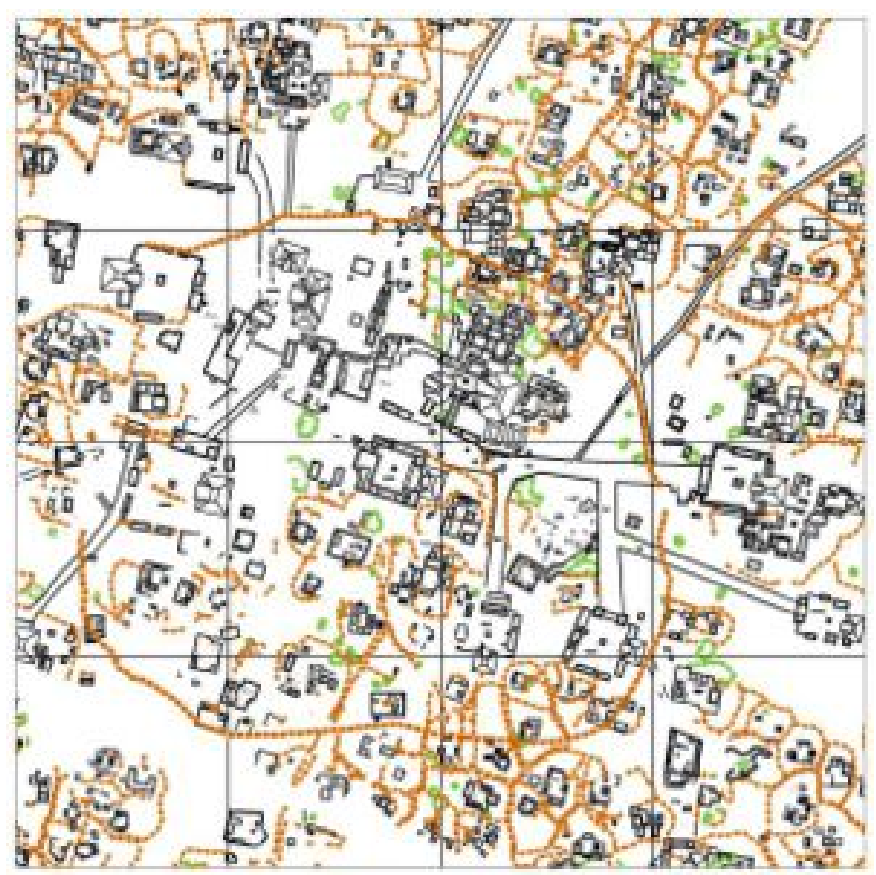

Figure 2. Map of the central $1 \mathrm{~km}^{2}$ of Chunchucmil. Albarrada (stone fences) groups can be seen as dotted lines. The large stone circle was Chunchucmil's last desperate defense when Chunchucmil was conquered. 


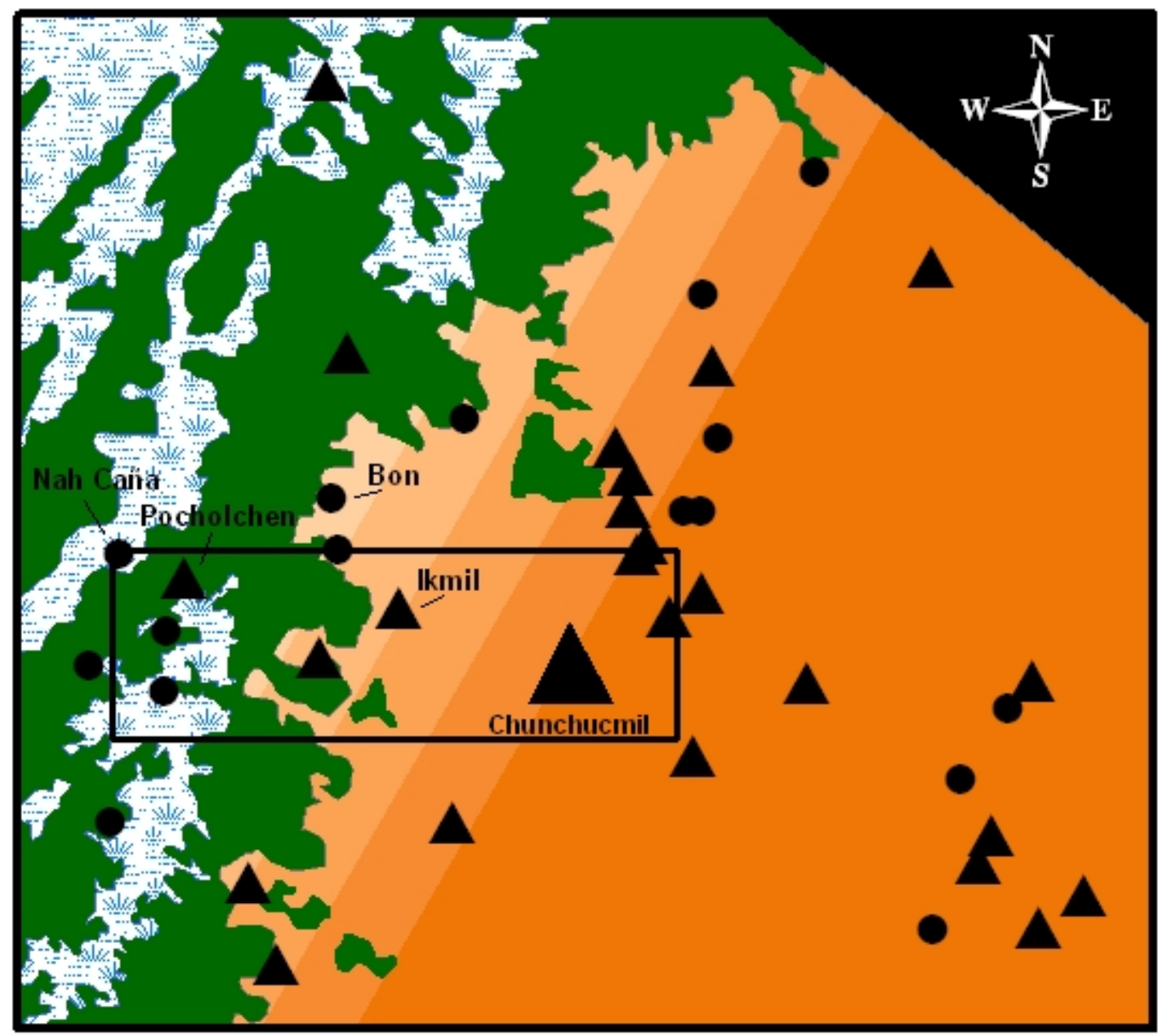

\section{Legend}

C Teriany Site

A Secondary Site

Vegetation

Type

No Data

Savanna'Karst PIain

Tzerel

W........ Seasonal Suramp

Figure 3. Vegetation map of the agricultural resources of Chunchucmil created from an AISAR image (synthetic aperture radar) with locations of ancient Chunchucmil, rural sites, and the area that geospatial analyses were performed (box). 


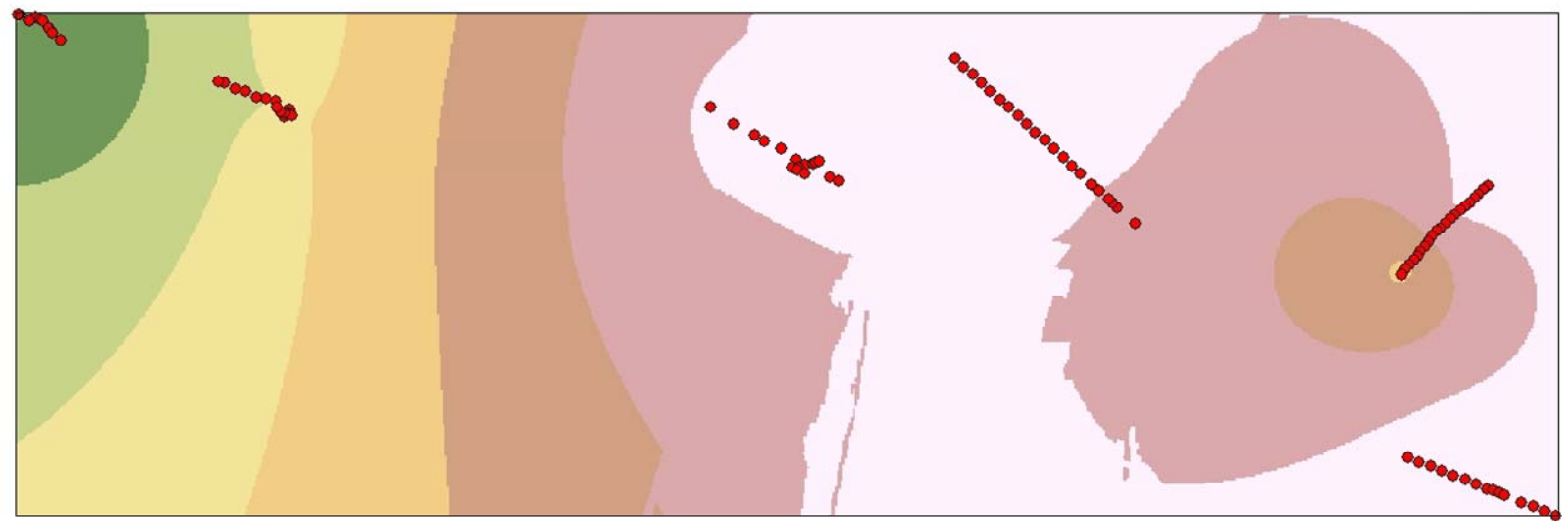

Legend

- Profile Locations

USDA Classification

Great Groups

Petraquept

Endoaquent

Ustorthent

Haplustoll

Calciustoll

Paleustoll

Paleustalf

Figure 4. Soil map of great groups under the United States Department of Agriculture classification created using geospatial analysis in $\operatorname{ArcMap}^{\circledR}$. 


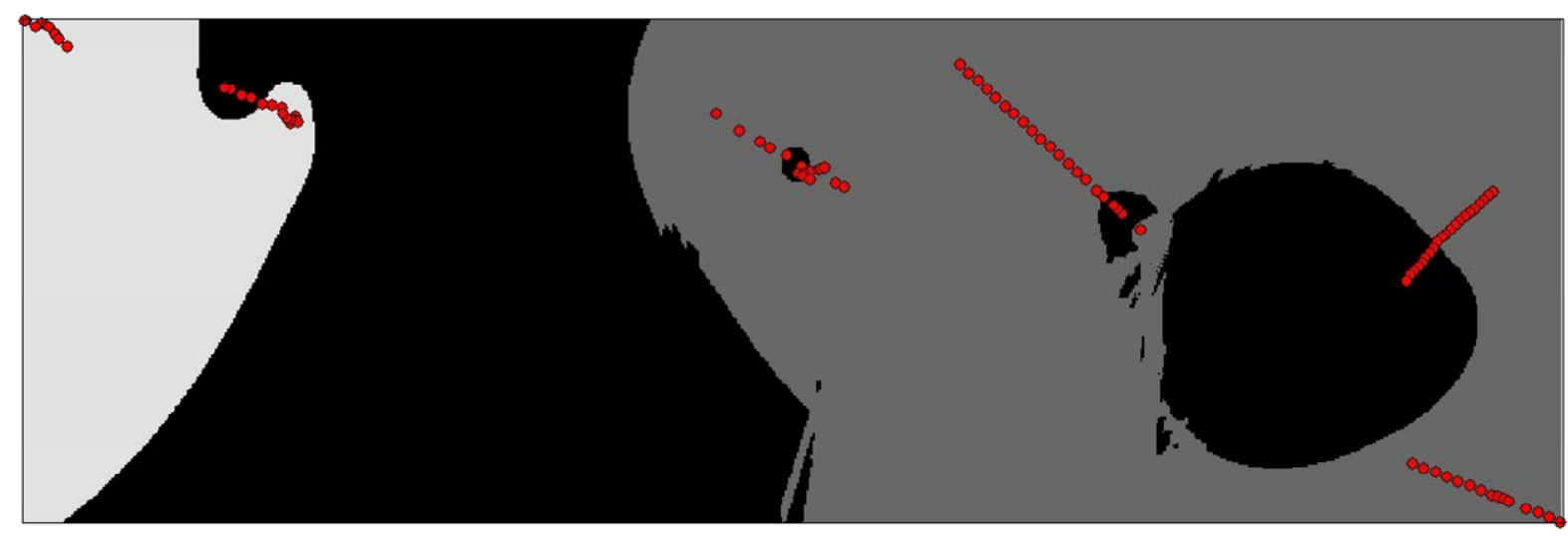

\section{Legend}

- Profile Locations Maya Classificati $\square$ Saklu'um Boxlu'um Kancab

Figure 5. Soil map under the Maya classification created using geospatial analysis in ArcMap $^{\circledR}$. 


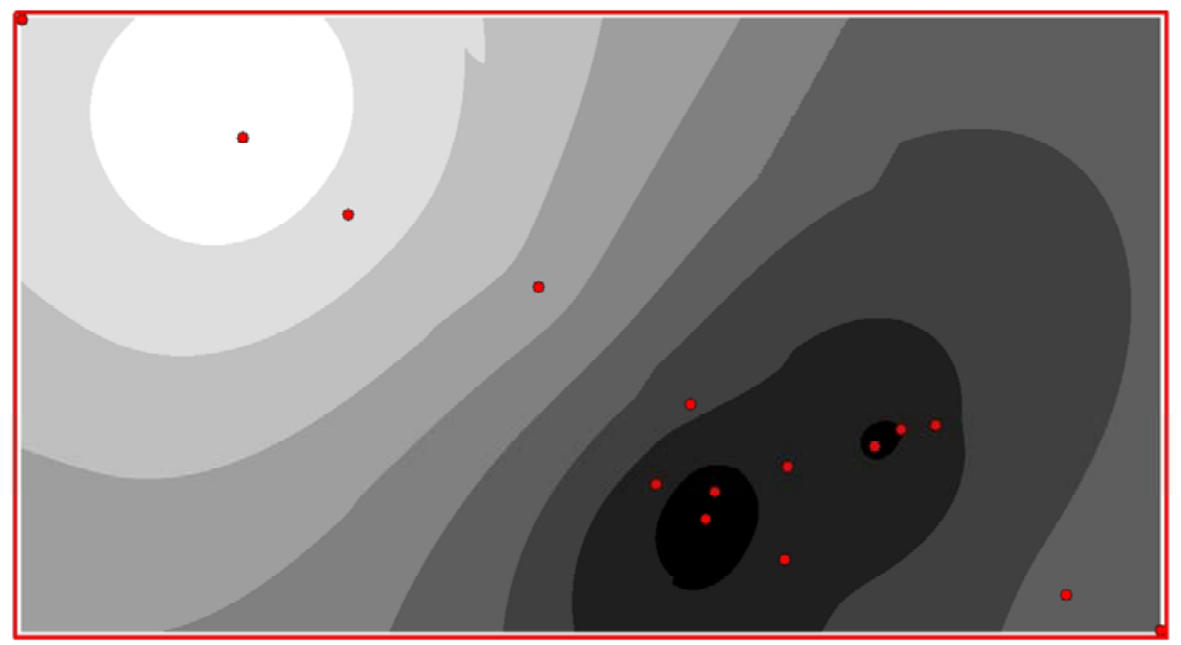

Legend

- Profile Locations BC-Ikmil g BC / kg of soil $0.50-0.55$ $0.55-0.60$ $0.60-0.65$ $0.65-0.70$ $0.70-0.75$

$0.75-0.80$

$0.80-0.84$

$0.84-0.89$

$0.89-0.94$

Figure 6. Black Carbon distribution in and around the rural site if Ikmil. 


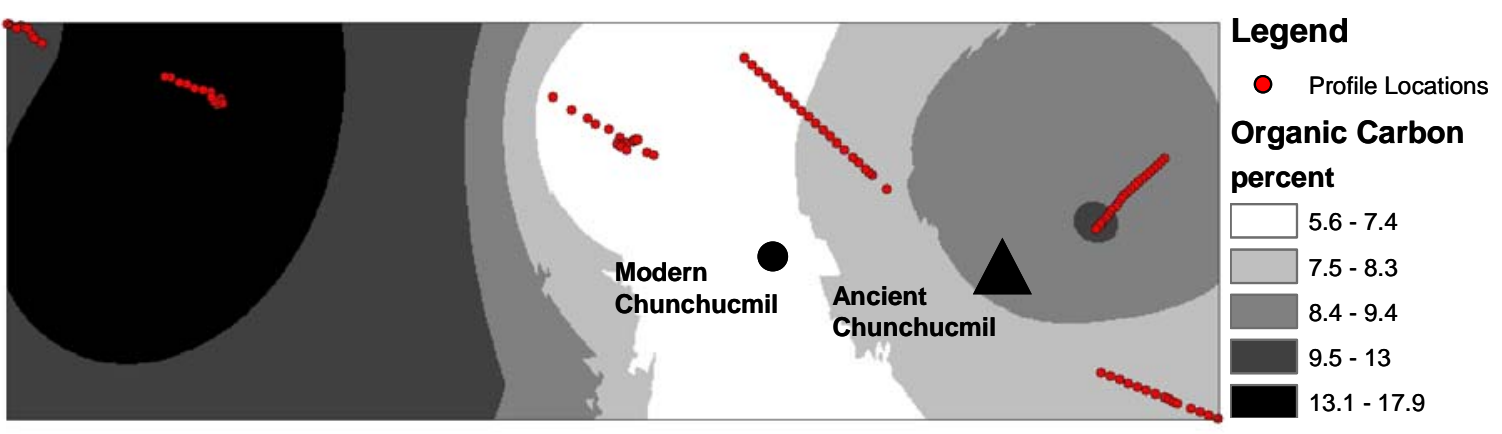

Figures 7. Isopleth map of soil organic carbon across a portion of ancient Chunchucmil's sustaining area. 


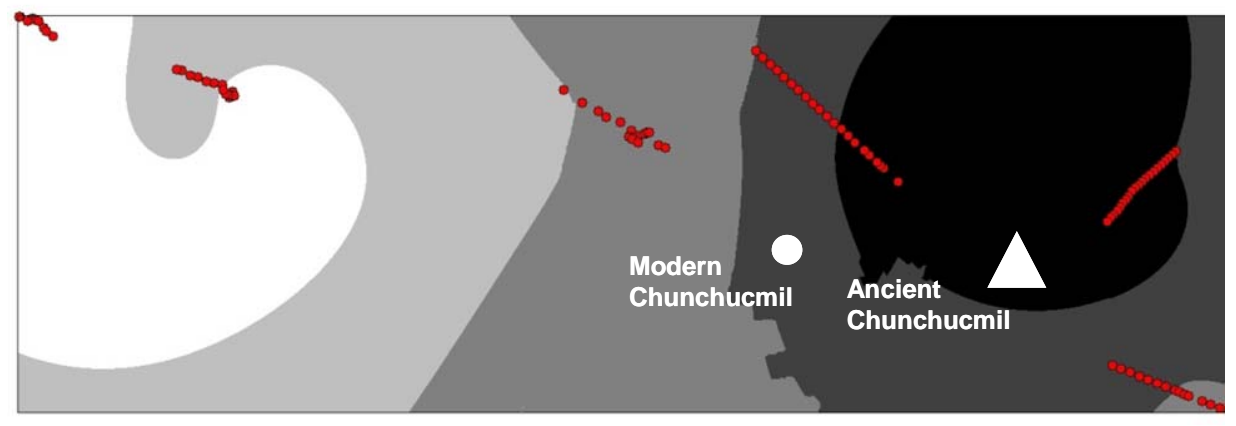

\section{Legend}

- Profile Locations

Calcium

ppm

$489-498$

$499-506$

$507-538$

$539-560$

$561-616$

Figures 8. Isopleth map of soil exchangeable calcium across a portion of ancient Chunchucmil's sustaining area. 


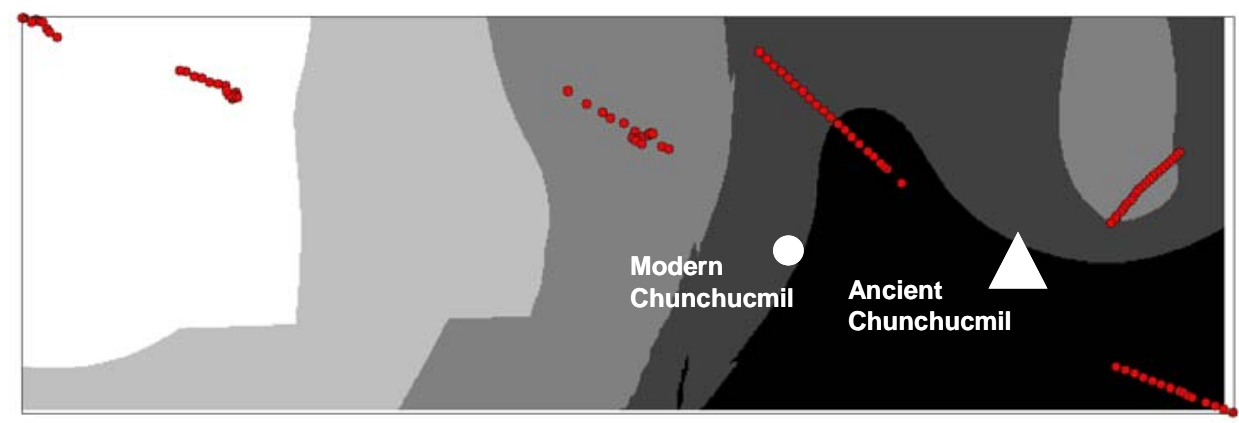

Legend

- Profile Locations

Profile depth

cm

Figures 9. Isopleth map of soil profile depth across a portion of ancient Chunchucmil's sustaining area. 
Table 1. Physical and chemical properties of selected representative profiles and mean values of all A horizons for Kancab

\begin{tabular}{|c|c|c|c|c|c|c|c|c|c|c|c|c|c|c|c|c|c|c|c|}
\hline Profile & $\begin{array}{l}\text { Great } \\
\text { Group }\end{array}$ & Horizon & $\begin{array}{l}\text { Depth } \\
(\mathrm{cm})\end{array}$ & Dry color & $\begin{array}{c}\text { Gravel } \\
(\%)\end{array}$ & $\begin{array}{l}\text { Clay } \\
(\%)\end{array}$ & $\mathrm{pH}$ & $\begin{array}{c}\mathrm{EC} \\
(\mathrm{dS} / \mathrm{m})\end{array}$ & $\begin{array}{c}\mathrm{CEC} \\
(\mathrm{cmol} / \mathrm{kg})\end{array}$ & $\begin{array}{c}\mathrm{CaCO} 3 \\
\text { equiv. } \\
(\%)\end{array}$ & $\begin{array}{c}\mathrm{T}- \\
\mathrm{N} \\
(\%)\end{array}$ & $\begin{array}{l}\mathrm{T}- \\
\mathrm{OC} \\
(\%)\end{array}$ & $\begin{array}{c}\mathrm{BC} \\
(\mathrm{g} / \mathrm{kg} \\
\text { soil) }\end{array}$ & $\begin{array}{c}\mathrm{P} \\
(\mathrm{mg} / \mathrm{kg})\end{array}$ & $\begin{array}{c}\mathrm{K} \\
(\mathrm{mg} / \mathrm{kg})\end{array}$ & $\begin{array}{c}\mathrm{Zn} \\
(\mathrm{mg} / \mathrm{kg})\end{array}$ & $\begin{array}{c}\mathrm{Cu} \\
(\mathrm{mg} / \mathrm{kg})\end{array}$ & $\begin{array}{c}\mathrm{Mn} \\
(\mathrm{mg} / \mathrm{kg})\end{array}$ & $\begin{array}{c}\mathrm{Fe} \\
(\mathrm{mg} / \mathrm{kg})\end{array}$ \\
\hline \multirow[t]{2}{*}{ IK 7} & Paleustoll & A & $0-7$ & $5 Y R 4 / 4$ & nd & 46 & 6.7 & 0.4 & 107.2 & 2.7 & 0.2 & 2.9 & 0.72 & 4.4 & 16.0 & 0.2 & 0.6 & 13.3 & 13.2 \\
\hline & & $\mathrm{Bw}$ & $7-30$ & $5 \mathrm{YR} 4 / 6$ & nd & 46 & 7.2 & 0.3 & nd & 2.5 & 0.1 & 1.2 & 0.66 & 3.2 & 0.0 & 0.3 & 0.4 & 4.0 & 2.5 \\
\hline \multirow[t]{2}{*}{ NT 4} & Paleustalf & $\mathrm{A}$ & $0-15$ & $5 \mathrm{YR} 2.5 / 2$ & 58 & 17 & 7.4 & 0.0 & nd & 9.4 & 0.9 & 11.4 & nd & 8.7 & 105.6 & 1.1 & 1.3 & 40.0 & 12.9 \\
\hline & Argillic H. & $\mathrm{Bt}$ & $15-26$ & $5 \mathrm{YR} 3 / 3$ & 52 & 35 & 7.7 & 0.5 & nd & 11.8 & 0.7 & 7.4 & nd & 7.3 & 19.2 & 0.0 & 1.1 & 25.3 & 10.5 \\
\hline \multirow[t]{2}{*}{ ET 14} & Paleustoll & A & $5-10$ & $5 \mathrm{YR} 4 / 6$ & 0 & 34 & 7.2 & 0.5 & nd & 1.3 & 0.3 & 4.3 & nd & 4.9 & 54.4 & 0.2 & 0.7 & 17.1 & 14.0 \\
\hline & & $\mathrm{Bw}$ & $15-20$ & $5 \mathrm{YR} 5 / 6$ & 0 & 26 & 7.4 & 0.2 & nd & 1.2 & 0.1 & 3.0 & nd & 7.2 & 35.2 & 0.0 & 0.3 & 14.7 & 8.1 \\
\hline \multirow[t]{3}{*}{ NW 24} & Paleustalf & $\mathrm{A}$ & $5-10$ & $5 \mathrm{YR} 4 / 6$ & 17 & 38 & 7.0 & 0.3 & 57.6 & 1.5 & 0.2 & 3.4 & nd & 4.9 & 9.6 & 0.4 & 0.4 & 7.5 & 9.6 \\
\hline & Argillic H. & B1 & 30 & $5 Y R 4 / 6$ & 25 & 46 & 7.4 & 0.3 & 48.0 & 2.7 & 0.0 & 1.2 & nd & 5.3 & 12.8 & 0.1 & 0.3 & 2.5 & 2.1 \\
\hline & & $\mathrm{B} 2 \mathrm{t}$ & $35-40$ & $5 \mathrm{YR} 4 / 6$ & 7 & 33 & 7.4 & 0.2 & nd & 2.9 & 0.0 & 1.2 & nd & 5.2 & 0.0 & 0.1 & 0.4 & 3.0 & 2.4 \\
\hline \multicolumn{3}{|c|}{ Mean for all A horizons $(n=44)$} & 21 & & 14 & 33 & 7.2 & 0.5 & nd & 4.5 & 0.5 & 6.4 & 0.50 & $6.4 \mathrm{~L}$ & $85 \mathrm{M}$ & $0.8 \mathrm{M}$ & $0.7 \mathrm{H}$ & $24.2 \mathrm{H}$ & $11.4 \mathrm{H}$ \\
\hline
\end{tabular}

Abbreviations: 1. nd - not determined; 2. L - Low or deficient; M - Marginal; H - High or sufficient for common modern crops (Havlin et al., 2005) 
Table 2. Physical and chemical properties of selected representative profiles and mean values of all A horizons for Boxlu'um

\begin{tabular}{|c|c|c|c|c|c|c|c|c|c|c|c|c|c|c|c|c|c|c|c|}
\hline Profile & $\begin{array}{l}\text { Great } \\
\text { Group }\end{array}$ & Horizon & $\begin{array}{l}\text { Depth } \\
(\mathrm{cm})\end{array}$ & $\begin{array}{l}\text { Dry } \\
\text { color }\end{array}$ & $\begin{array}{c}\text { Gravel } \\
(\%)\end{array}$ & $\begin{array}{l}\text { Clay } \\
(\%)\end{array}$ & $\mathrm{pH}$ & $\begin{array}{c}\mathrm{EC} \\
(\mathrm{dS} / \mathrm{m})\end{array}$ & $\begin{array}{c}\mathrm{CEC} \\
(\mathrm{cmol} / \mathrm{kg})\end{array}$ & $\begin{array}{c}\mathrm{CaCO} 3 \\
\text { equiv. } \\
(\%)\end{array}$ & $\begin{array}{c}\mathrm{T}- \\
\mathrm{N} \\
(\%)\end{array}$ & $\begin{array}{l}\mathrm{T}- \\
\mathrm{OC} \\
(\%)\end{array}$ & $\begin{array}{c}\mathrm{BC} \\
(\mathrm{g} / \mathrm{kg} \\
\text { soil) }\end{array}$ & $\begin{array}{c}\mathrm{P} \\
(\mathrm{mg} / \mathrm{kg})\end{array}$ & $\underset{(\mathrm{mg} / \mathrm{kg})}{\mathrm{K}}$ & $\begin{array}{c}\mathrm{Zn} \\
(\mathrm{mg} / \mathrm{kg})\end{array}$ & $\begin{array}{c}\mathrm{Cu} \\
(\mathrm{mg} / \mathrm{kg})\end{array}$ & $\begin{array}{c}\mathrm{Mn} \\
(\mathrm{mg} / \mathrm{kg})\end{array}$ & $\begin{array}{c}\mathrm{Fe} \\
(\mathrm{mg} / \mathrm{kg})\end{array}$ \\
\hline PO 5 & Haplustoll & A & $0-8$ & 10YR2/1 & 16 & 19 & 7.5 & 1.3 & 100.8 & 10.9 & 1.5 & 16.2 & 1.12 & 13.5 & 137.6 & 0.3 & 0.0 & 11.7 & 18.7 \\
\hline IK 1 & Calciustoll & $\mathrm{A}$ & $0-7$ & 10YR3/2 & 25 & 28 & 7.3 & 0.5 & 68.8 & 33.5 & 0.8 & 9.8 & 0.79 & 13.1 & 115.2 & 2.0 & 0.8 & 18.8 & 13.0 \\
\hline \multirow[t]{2}{*}{ NT 19} & Haplustoll & A1 & $0-15$ & 10YR2/1 & 0 & 36 & 7.5 & 0.7 & 73.6 & 3.0 & 0.8 & 10.6 & nd & 7.8 & 214.4 & nd & nd & nd & nd \\
\hline & & $\mathrm{A} 2$ & $15-25$ & $10 \mathrm{YR} 3 / 2$ & 24 & 36 & 7.6 & 0.4 & & 2.7 & 0.4 & 5.0 & nd & 5.1 & 44.8 & 0.0 & 0.9 & 15.9 & 20.1 \\
\hline Mean fo & $1 \mathrm{~A}$ horizons & $1=36)$ & 12 & & 29 & 28 & 7.5 & 1.1 & nd & 18.8 & 1.2 & 15.1 & 0.80 & $13.9 \mathrm{H}$ & $144 \mathrm{H}$ & $1.3 \mathrm{H}$ & $0.6 \mathrm{M}$ & $16.6 \mathrm{H}$ & $18.6 \mathrm{H}$ \\
\hline
\end{tabular}

Abbreviations: 1. nd - not determined; 2. M - Marginal; H - High or sufficient for common modern crops (Havlin et al., 2005) 
Table 3. Physical and chemical properties of selected representative profiles and mean values of all A horizons for Saklu'um

\begin{tabular}{|c|c|c|c|c|c|c|c|c|c|c|c|c|c|c|c|c|c|c|c|}
\hline Profile & $\begin{array}{c}\text { Great } \\
\text { Group }\end{array}$ & Horizon & $\begin{array}{l}\text { Depth } \\
\text { (cm) }\end{array}$ & $\begin{array}{l}\text { Dry } \\
\text { color }\end{array}$ & $\begin{array}{c}\text { Gravel } \\
(\%)\end{array}$ & $\begin{array}{l}\text { Clay } \\
(\%)\end{array}$ & $\mathrm{pH}$ & $\begin{array}{c}\mathrm{EC} \\
(\mathrm{dS} / \mathrm{m})\end{array}$ & $\begin{array}{c}\mathrm{CEC} \\
(\mathrm{cmol} / \mathrm{kg})\end{array}$ & $\begin{array}{l}\mathrm{CaCO} 3 \\
\text { equiv. } \\
(\%)\end{array}$ & $\begin{array}{c}\mathrm{T}- \\
\mathrm{N} \\
(\%)\end{array}$ & $\begin{array}{l}\mathrm{T}- \\
\mathrm{OC} \\
(\%)\end{array}$ & $\begin{array}{l}\mathrm{BC} \\
(\mathrm{g} / \mathrm{kg} \\
\text { soil) }\end{array}$ & $\begin{array}{c}\mathrm{P} \\
(\mathrm{mg} / \mathrm{kg})\end{array}$ & $\begin{array}{c}\mathrm{K} \\
(\mathrm{mg} / \mathrm{kg})\end{array}$ & $\begin{array}{c}\mathrm{Zn} \\
(\mathrm{mg} / \mathrm{kg})\end{array}$ & $\begin{array}{c}\mathrm{Cu} \\
(\mathrm{mg} / \mathrm{kg})\end{array}$ & $\begin{array}{c}\mathrm{Mn} \\
(\mathrm{mg} / \mathrm{kg})\end{array}$ & $\begin{array}{c}\mathrm{Fe} \\
(\mathrm{mg} / \mathrm{kg})\end{array}$ \\
\hline PO 16 & Petraquept & A & $0-17$ & $2.5 \mathrm{Y} 7 / 2$ & 0 & 45 & 7.7 & 1.5 & nd & 62.8 & 0.3 & 4.5 & 0.52 & 8.2 & 51.2 & 0.0 & 0.1 & 1.4 & 16.1 \\
\hline NA 2 & Endoaquent & A & $0-3$ & $2.5 \mathrm{Y} 7 / 2$ & 0 & 37 & 7.5 & 1.7 & 41.6 & 84.9 & 0.5 & 4.2 & 0.78 & 16.7 & 86.4 & 0.5 & 1.0 & 5.8 & 40.9 \\
\hline \multirow[t]{2}{*}{ NA 9} & Endoaquent & A & $0-2$ & $2.5 \mathrm{Y} 6 / 2$ & 0 & 23 & 7.7 & 0.6 & nd & 61.8 & 0.4 & 5.7 & 0.52 & 13.3 & 320.0 & 0.8 & 0.8 & 0.8 & 41.2 \\
\hline & & $\mathrm{Ck}$ & $2-10$ & $2.5 \mathrm{Y} 7 / 2$ & 0 & 35 & 7.6 & 1.7 & nd & 69.2 & 0.3 & 2.1 & 0.30 & 6.1 & 25.6 & 0.0 & 0.6 & 0.0 & 15.0 \\
\hline Mean fo & all A horizon & $(n=9)$ & 10 & & 8 & 29 & 7.6 & 1.1 & nd & 44.3 & 0.9 & 8.8 & 0.58 & $11.1 \mathrm{M}$ & $118 \mathrm{M}$ & $0.8 \mathrm{M}$ & $0.7 \mathrm{H}$ & $6.8 \mathrm{H}$ & $33.6 \mathrm{H}$ \\
\hline
\end{tabular}

Abbreviations: 1. nd - not determined; 2. M - Marginal; H - High or sufficient for common modern crops (Havlin et al., 2005) 
Table 4. Soil properties that were significantly different $(P<0.05)$ between boxlu'um from occupied and unoccupied areas.

\begin{tabular}{|c|c|c|}
\hline Soil Properties & $\begin{array}{l}\text { Boxlu'um- } \\
\text { occupied } \\
\text { areas }\end{array}$ & $\begin{array}{l}\text { Boxlu'um- } \\
\text { unoccupied } \\
\text { areas }\end{array}$ \\
\hline $\begin{array}{r}\text { \%CaCO3 } \\
\text { equivalent }\end{array}$ & 24.4 & 9.6 \\
\hline$\% \mathrm{~T}-\mathrm{N}$ & 1.0 & 1.8 \\
\hline$\% \mathrm{~T}-\mathrm{OC}$ & 12.6 & 23.2 \\
\hline$\% \mathrm{BC}$ of $\mathrm{SOC}$ & 1.0 & 0.3 \\
\hline BC $\mathrm{g} / \mathrm{kg}$ soil & 909.2 & 635.3 \\
\hline $\mathrm{P}$ & 11.4 & 22.9 \\
\hline EC & 1.0 & 1.5 \\
\hline $\mathrm{Cu}$ & 0.78 & 0.03 \\
\hline $\mathrm{Mn}$ & 20.0 & 8.1 \\
\hline $\mathrm{Zn}$ & 1.7 & 0.3 \\
\hline $\mathrm{Na}$ & 9.0 & 17.4 \\
\hline
\end{tabular}




\section{APPENDIX A}

Table A-1. Boxlu'um All: Physical and Chemical Properties

\begin{tabular}{|c|c|c|c|c|c|c|c|c|c|c|c|c|c|c|c|c|c|}
\hline $\begin{array}{l}\text { Sample } \\
\text { Name } \\
\end{array}$ & Hor. & $\begin{array}{l}\text { Depth } \\
\text { (cm) }\end{array}$ & $\begin{array}{l}\text { Great } \\
\text { Group } \\
\end{array}$ & $\begin{array}{l}\text { Soil Color } \\
\text { Dry 10YR }\end{array}$ & $\mathrm{Str}^{1}$ & \%Gravel & $\begin{array}{l}\text { Text }^{2} \\
\text { Class } \\
\end{array}$ & CaCO3 equiv & \begin{tabular}{l} 
Total N \\
\hdashline$\%-\%-$ \\
\end{tabular} & $\begin{array}{l}\text { Total O.C. } \\
-\end{array}$ & $\begin{array}{c}\text { Black Carbon } \\
\% \text { of O.C. }\end{array}$ & $\mathrm{pH}$ & EC & P-mg/kg & $\mathrm{K}-\mathrm{mg} / \mathrm{kg}$ & Cu-mg/kg & $\mathrm{Zn}-\mathrm{mg} / \mathrm{kg}$ \\
\hline PO 2 & $A$ & $0-10$ & Haplustoll & $2 / 1$ & g & 29 & nd & 11.93 & 2.25 & 34.37 & nd & 7.39 & 2 & 35.5 & 220.8 & 0.1 & 0.5 \\
\hline $\mathrm{PO} 3$ & A & $0-4$ & Haplustoll & $2 / 2$ & $\mathrm{~s}$ & 9 & nd & 8.26 & 2.24 & 27.11 & 0.35 & 7.41 & 1.3 & 24.9 & 185.6 & 0.0 & 0.4 \\
\hline PO 4 & $A$ & $0-4$ & Haplustoll & $2 / 1$ & $g$ & 35 & nd & 12.58 & 2.42 & 30.69 & 0.26 & 7.58 & 2 & 46.3 & 236.8 & 0.0 & 0.4 \\
\hline PO 5 & $A$ & $0-8$ & Haplustoll & $2 / 1$ & $\mathrm{~g}$ & 16 & nd & 10.86 & 1.46 & 16.20 & 0.77 & 7.45 & 1.3 & 13.5 & 137.6 & 0.0 & 0.3 \\
\hline PO 6 & $A$ & $0-1$ & Haplustoll & $2 / 1$ & $g$ & 21 & nd & 16.97 & 2.28 & 32.86 & nd & 7.48 & 1.5 & 43.5 & 294.4 & 0.0 & 1.1 \\
\hline PO 7 & $\mathrm{~A}$ & $0-17$ & Calciustoll & $3 / 1$ & $\mathrm{~s}$ & 30 & $\mathrm{cl}$ & 24.80 & 0.46 & 5.78 & 1.25 & 7.76 & 0.5 & 14.4 & 25.6 & 0.2 & 0.6 \\
\hline PO $8 \mathrm{~A}$ & $A$ & $0-20$ & Paleustoll & $2 / 2$ & $\mathrm{~s}$ & 10 & $\mathrm{sl}$ & 53.73 & 1.28 & 15.65 & 0.30 & 7.06 & 6.6 & 26.3 & 137.6 & 0.1 & 0.0 \\
\hline PO 8 B & $\mathrm{A} 2$ & $20-44$ & & $3 / 2$ & $s$ & 11 & $\mathrm{cl}$ & 68.71 & 0.89 & 10.15 & 0.24 & 7.25 & 5.1 & 20.6 & 102.4 & 0.0 & 0.0 \\
\hline PO $8 \mathrm{C}$ & $\mathrm{Ck}$ & $44+$ & Calcic H. & $6 / 2$ & $\mathrm{~s}$ & 9 & $\mathrm{cl}$ & 85.03 & & & 0.35 & 7.67 & 5.6 & 12.3 & 83.2 & 0.0 & 0.0 \\
\hline PO 9 & $A$ & $0-13$ & Paleustoll & $2 / 2$ & $g$ & 25 & nd & 6.19 & 1.82 & 23.66 & nd & 7.27 & 1.6 & 23.1 & 198.4 & 0.0 & 0.2 \\
\hline PO 10 & A & $0-3$ & Paleustoll & $2 / 2$ & $\mathrm{~s}$ & 7 & nd & 6.39 & 2.55 & 35.43 & 0.15 & 7.26 & 1 & 22.9 & 208.0 & 0.0 & 0.3 \\
\hline PO 12 & $\mathrm{~A}$ & $0-6$ & Paleustoll & $2 / 2$ & $g$ & 14 & $\mathrm{sl}$ & nd & nd & nd & nd & nd & nd & nd & nd & nd & nd \\
\hline PO 13 & $\mathrm{~A}$ & $0-6$ & Calciustoll & $2 / 2$ & $\mathrm{~s}$ & 27 & sl & 16.40 & 1.42 & 15.83 & 0.29 & 7.68 & 0.7 & 14.8 & 166.4 & 0.0 & 0.2 \\
\hline PO 14 & $A$ & $0-21$ & Calciustoll & $3 / 1$ & $\mathrm{~s}$ & 48 & $\mathrm{cl}$ & 49.06 & 0.93 & 11.01 & 0.41 & 7.34 & 4.2 & 19.2 & 89.6 & 0.0 & 0.3 \\
\hline PO 15 & $A$ & $0-21$ & Paleustoll & $2 / 1$ & $\mathrm{~s}$ & 7 & $\mathrm{scl}$ & 4.59 & 1.48 & 16.30 & nd & 7.3 & 0.8 & 11.6 & 64.0 & 0.0 & 0.1 \\
\hline PO 17 & $A$ & $0-6$ & Paleustoll & $2 / 1$ & $\mathrm{~s}$ & 35 & nd & nd & nd & nd & nd & nd & nd & nd & nd & nd & nd \\
\hline PO 18 & $A$ & $0-11$ & Paleustoll & $3 / 2$ & $\mathrm{~s}$ & 4 & 1 & 8.27 & 1.29 & 13.91 & 0.32 & 7.46 & 0.6 & 14.1 & 140.8 & 0.0 & 0.1 \\
\hline NA 1 & $A$ & $0-11$ & Haplustoll & $2 / 1$ & $\mathrm{~s}$ & 44 & $\mathrm{scl}$ & 11.37 & 1.72 & 17.34 & 0.86 & 7.78 & 0.74 & 6.7 & 60.8 & 3.1 & 9.2 \\
\hline NA 3 & A & $0-25$ & Paleustoll & $3 / 1$ & $\mathrm{~s}$ & 43 & $\mathrm{scl}$ & 44.36 & 0.69 & 8.67 & nd & 7.61 & 0.51 & 5.5 & 67.2 & 0.7 & 0.0 \\
\hline NA 4 & A & $0-6$ & Calciustoll & $3 / 1$ & $\mathrm{~s}$ & 43 & nd & 52.69 & 0.99 & 9.68 & 0.45 & 7.5 & 0.98 & 18.1 & 262.4 & 0.5 & 2.9 \\
\hline NA 5 & $\mathrm{~A}$ & $0-15$ & Calciustoll & $3 / 1$ & $\mathrm{~s}$ & 45 & $\mathrm{scl}$ & 28.19 & 0.73 & 7.41 & nd & 7.83 & 0.47 & 4.5 & 176.0 & 0.7 & 3.0 \\
\hline NA 6 & A1 & $0-4$ & Haplustoll & $3 / 1$ & s & 0 & $\mathrm{scl}$ & 11.83 & 1.91 & 23.48 & nd & 7.47 & 1.28 & 16.6 & 339.2 & nd & nd \\
\hline NA 6 B & $\mathrm{A} 2$ & $4-10$ & & $3 / 1$ & $\mathrm{~s}$ & 52 & $\mathrm{cl}$ & 13.08 & 1.03 & 11.13 & nd & 7.81 & 0.75 & 4.9 & 57.6 & 1.3 & 1.1 \\
\hline IK 1 & $A$ & $0-7$ & Calciustoll & $3 / 2$ & $\mathrm{~s}$ & 25 & $\mathrm{cl}$ & 33.49 & 0.77 & 9.78 & 0.84 & 7.3 & 0.52 & 13.1 & 115.2 & 0.8 & 2.0 \\
\hline IK 2 & A & $0-10$ & Paleustoll & $2 / 2$ & $\mathrm{~s}$ & 19 & $\mathrm{scl}$ & 4.69 & 0.77 & 9.37 & 0.83 & 7.12 & 0.45 & 6.9 & 265.6 & 0.7 & 0.8 \\
\hline IK 11 & A & $0-9$ & Paleustoll & $2 / 2$ & $\mathrm{~s}$ & 17 & $\mathrm{cl}$ & 10.08 & 0.48 & 6.22 & 1.98 & 7.32 & 0.365 & 6.2 & 28.8 & 1.0 & 0.8 \\
\hline IK 12 & $A$ & $0-5$ & Calciustoll & $3 / 2$ & $\mathrm{~s}$ & 18 & $\mathrm{cl}$ & 46.19 & 0.66 & 7.86 & 1.33 & 7.27 & 0.54 & 7.5 & 57.6 & 0.5 & 1.2 \\
\hline
\end{tabular}




\begin{tabular}{|c|c|c|c|c|c|c|c|c|c|c|c|c|c|c|c|c|c|}
\hline IK 15 & A & $0-2$ & Haplustoll & $3 / 2$ & $\mathrm{~s}$ & 22 & 1 & 45.95 & 0.60 & 7.29 & 1.01 & 7.28 & 0.37 & 7.6 & 169.6 & 0.5 & 1.0 \\
\hline NT 3 & A & $0-12$ & Haplustoll & $2 / 2$ & $\mathrm{~s}$ & 13 & $\mathrm{cl}$ & 4.77 & 1.21 & 13.83 & nd & 7.59 & 0.9 & 9.9 & 160.0 & 1.8 & 5.1 \\
\hline NT 12 & A & $0-11$ & Paleustoll & $2 / 1$ & $\mathrm{~s}$ & 40 & nd & 7.28 & 1.22 & 13.93 & nd & 7.51 & 0.92 & 5.2 & 118.4 & 0.7 & 1.1 \\
\hline NT 14 & $\mathrm{O}$ & $0-20$ & Ustorthent & $2 / 1$ & nd & 0 & nd & 24.09 & nd & nd & nd & nd & nd & 14.0 & 345.6 & 0.7 & 0.0 \\
\hline NT 17 & A & $0-13$ & Haplustoll & $2 / 1$ & $\mathrm{~s}$ & 54 & nd & 21.52 & 1.39 & 17.82 & nd & 7.64 & 0.81 & 5.7 & 147.2 & 0.8 & 2.0 \\
\hline NT 18 & $\mathrm{~A}$ & $0-20$ & Haplustoll & $2 / 1$ & $\mathrm{~s}$ & 34 & nd & 18.20 & 1.24 & 15.41 & nd & 7.61 & 0.69 & 5.2 & 188.8 & 1.1 & 1.0 \\
\hline NT $19 \mathrm{~A}$ & $\mathrm{~A} 1$ & $0-15$ & Haplustoll & $2 / 1$ & $\mathrm{~s}$ & 0 & $\mathrm{cl}$ & 3.02 & 0.75 & 10.64 & nd & 7.47 & 0.67 & 7.8 & 214.4 & nd & nd \\
\hline NT $19 \mathrm{~B}$ & $\mathrm{~A} 2$ & $15-25$ & & $3 / 2$ & $s$ & 24 & $\mathrm{cl}$ & 2.68 & 0.41 & 5.01 & nd & 7.57 & 0.395 & 5.1 & 44.8 & 0.9 & 0.0 \\
\hline NT 20 & A & $0-17$ & Haplustoll & $2 / 1$ & $\mathrm{~s}$ & 53 & nd & 25.59 & 1.13 & 14.03 & nd & 7.66 & 0.71 & 4.7 & 185.6 & 0.9 & 1.0 \\
\hline NT 21 & $\mathrm{O}$ & $0-2$ & Ustorthent & $2 / 1$ & nd & 0 & nd & nd & nd & nd & nd & nd & nd & 9.5 & 310.4 & nd & nd \\
\hline ET 2 & $A$ & $0-5$ & Calciustoll & $3 / 3$ & s & 27 & $\mathrm{cl}$ & 5.10 & 0.89 & 10.89 & nd & 7.51 & 0.56 & 9.7 & 102.4 & 0.7 & 1.5 \\
\hline ET 2 & Bw & $5-20$ & Calcic H. & $3 / 3$ & $\mathrm{~s}$ & 34 & nd & 17.03 & 0.67 & 8.25 & nd & nd & nd & 7.6 & 44.8 & 1.0 & 0.3 \\
\hline ET 6 & A & $5-10$ & nd & $3 / 3$ & $\mathrm{~s}$ & 0 & $\mathrm{cl}$ & 4.41 & 0.69 & 9.05 & nd & 7.58 & 0.44 & 7.5 & 185.6 & 0.6 & 0.9 \\
\hline ET 7 & $\mathrm{~A} 1 / \mathrm{A} 2$ & $10-15$ & nd & $2 / 2$ & $\mathrm{~s}$ & 47 & $\mathrm{sl}$ & 6.41 & 0.85 & 9.73 & nd & 7.44 & 0.98 & 9.0 & 64.0 & 0.5 & 0.7 \\
\hline NW 19 & $\mathrm{~A} 2$ & $0-20$ & Calciustoll & $2 / 1$ & $s$ & 28 & $\mathrm{scl}$ & 26.84 & 0.99 & 11.38 & nd & 7.22 & 0.7 & 7.9 & 28.8 & 0.6 & 0.6 \\
\hline NW 21 & $\mathrm{~A} 2 / \mathrm{Bw}$ & $15-20$ & Calciustoll & $3 / 3$ & $\mathrm{~s}$ & 57 & $\mathrm{scl}$ & 17.87 & 0.94 & 10.15 & nd & nd & nd & 7.2 & 32.0 & 0.5 & 0.6 \\
\hline NW 22 & $\mathrm{~A} 2 / \mathrm{Bw}$ & nd & nd & $2 / 2$ & $\mathrm{~s}$ & 35 & $\mathrm{C}$ & 5.23 & 0.96 & 10.37 & nd & 7.06 & 0.64 & 6.4 & 35.2 & 0.4 & 0.8 \\
\hline NW 35 & A & nd & nd & $2 / 2$ & $\mathrm{~s}$ & 56 & $\mathrm{scl}$ & 9.08 & 1.25 & 16.61 & nd & 7.06 & 0.86 & 9.6 & 115.2 & 0.8 & 3.9 \\
\hline NW 37 & A mixed & nd & nd & $2 / 2$ & $\mathrm{~s}$ & 58 & $\mathrm{scl}$ & 14.71 & 0.83 & 8.63 & nd & 7.22 & 0.96 & 6.3 & 41.6 & 0.4 & 0.3 \\
\hline
\end{tabular}

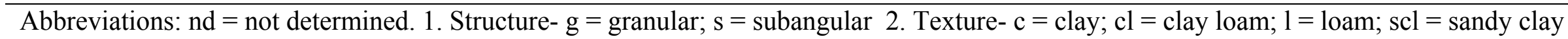
loam; sl = sandy loam. 
Table A-1 b. Descriptive Statistics: Boxlu'um

\begin{tabular}{|c|c|c|c|c|c|c|c|c|c|c|c|c|c|c|c|c|}
\hline & $\begin{array}{l}\text { Profile } \\
\text { Depth }\end{array}$ & chr/value & \%Gravel & \%Sand & \%Silt & \%Clay & $\begin{array}{c}\% \mathrm{CaCO} 3 \\
\text { equiv }\end{array}$ & $\begin{array}{l}\text { Tot } \\
\% \mathrm{~N} \\
\end{array}$ & $\begin{array}{c}\text { Tot } \\
\% \text { O.C. }\end{array}$ & $\begin{array}{c}\% \text { BC } \\
\text { of } \\
\text { O.C. }\end{array}$ & $\mathrm{pH}$ & $\mathrm{EC}$ & $\begin{array}{c}\mathrm{P}- \\
\mathrm{mg} / \mathrm{kg}\end{array}$ & $\mathrm{K}-\mathrm{mg} / \mathrm{kg}$ & $\begin{array}{c}\mathrm{Cu}- \\
\mathrm{mg} / \mathrm{kg}\end{array}$ & $\begin{array}{c}\mathrm{Zn}- \\
\mathrm{mg} / \mathrm{kg}\end{array}$ \\
\hline Mean & 11.85 & 0.69 & 28.52 & 44.74 & 27.25 & 28.01 & 18.83 & 1.23 & 15.12 & 0.71 & 7.46 & 1.13 & 13.88 & 143.81 & 0.57 & 1.33 \\
\hline Standard Error & 1.46 & 0.04 & 2.86 & 1.83 & 1.26 & 1.50 & 2.72 & 0.10 & 1.41 & 0.12 & 0.04 & 0.21 & 1.86 & 12.42 & 0.11 & 0.32 \\
\hline Median & 10.00 & 0.58 & 26.76 & 44.70 & 26.16 & 30.00 & 12.26 & 1.17 & 13.87 & 0.61 & 7.47 & 0.78 & 9.64 & 144.00 & 0.49 & 0.84 \\
\hline Mode & 10.00 & 1.00 & 0.00 & $\# N / A$ & 24.16 & 31.28 & $\# N / A$ & \#N/A & $\# N / A$ & \#N/A & 7.58 & 2.00 & 7.53 & 185.60 & \#N/A & \#N/A \\
\hline Standard Deviation & 8.52 & 0.27 & 17.16 & 8.79 & 6.06 & 7.21 & 15.87 & 0.58 & 8.22 & 0.50 & 0.21 & 1.20 & 10.84 & 72.41 & 0.64 & 1.83 \\
\hline Sample Variance & 72.67 & 0.07 & 294.60 & 77.28 & 36.74 & 51.93 & 251.97 & 0.34 & 67.63 & 0.25 & 0.04 & 1.44 & 117.59 & 5242.84 & 0.41 & 3.33 \\
\hline Kurtosis & 4.93 & -1.71 & -1.11 & -0.44 & -0.85 & -0.31 & -0.07 & -0.08 & 0.88 & 1.24 & -0.59 & 14.12 & 2.51 & -0.82 & 7.41 & 10.81 \\
\hline Skewness & 1.80 & 0.15 & 0.08 & 0.35 & 0.09 & -0.63 & 1.12 & 0.89 & 1.31 & 1.16 & -0.07 & 3.57 & 1.70 & 0.12 & 2.27 & 3.01 \\
\hline Range & 43.00 & 0.67 & 58.00 & 33.44 & 22.50 & 26.22 & 50.71 & 2.08 & 29.65 & 1.83 & 0.77 & 6.24 & 41.76 & 268.80 & 3.14 & 9.19 \\
\hline Minimum & 1.00 & 0.33 & 0.00 & 29.84 & 16.16 & 11.64 & 3.02 & 0.46 & 5.78 & 0.15 & 7.06 & 0.37 & 4.52 & 25.60 & 0.01 & 0.04 \\
\hline Maximum & 44.00 & 1.00 & 58.00 & 63.28 & 38.66 & 37.86 & 53.73 & 2.55 & 35.43 & 1.98 & 7.83 & 6.60 & 46.28 & 294.40 & 3.15 & 9.22 \\
\hline Sum & 403.00 & 24.67 & 1026.81 & 1029.07 & 626.70 & 644.22 & 640.21 & 41.79 & 514.10 & 11.39 & 253.55 & 38.30 & 471.94 & 4889.60 & 18.73 & 43.88 \\
\hline Count & 34 & 36 & 36 & 23 & 23 & 23 & 34 & 34 & 34 & 16 & 34 & 34 & 34 & 34 & 33 & 33 \\
\hline Conf. Level(95.0\%) & 2.97 & 0.09 & 5.81 & 3.80 & 2.62 & 3.12 & 5.54 & 0.20 & 2.87 & 0.27 & 0.07 & 0.42 & 3.78 & 25.26 & 0.23 & 0.65 \\
\hline
\end{tabular}


Table A-2. Kancab All: Physical and Chemical Properties

\begin{tabular}{|c|c|c|c|c|c|c|c|c|c|c|c|c|c|c|c|c|c|}
\hline $\begin{array}{c}\text { Sample } \\
\text { Name }\end{array}$ & Horizon & $\begin{array}{l}\text { Depth } \\
\text { (cm) }\end{array}$ & $\begin{array}{l}\text { Great } \\
\text { Group }\end{array}$ & $\begin{array}{l}\text { Soil Color } \\
\text { Dry 5YR }\end{array}$ & Str $^{1}$ & \%Gravel & $\begin{array}{l}\text { Text }^{2} \\
\text { Class } \\
\end{array}$ & CaCO3 equiv & 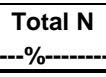 & $\begin{array}{l}\text { Total O.C. } \\
\end{array}$ & $\begin{array}{l}\text { Black Carbon } \\
\% \text { of O.C. }\end{array}$ & $\mathrm{pH}$ & EC & P-mg/kg & K-mg/kg & Cu-mg/kg & Zn-mg/kg \\
\hline IK 3 A & A & $0-10$ & Paleustoll & $3 / 2$ & $\mathrm{~s}$ & 29 & $\mathrm{cl}$ & 4.55 & 0.72 & 4.58 & 0.26 & 7.10 & 0.29 & 4.8 & 6.4 & 0.7 & 0.6 \\
\hline IK 3 B & Bw & $10-20$ & & $4 / 3$ & $\mathrm{~s}$ & 30 & $\mathrm{C}$ & 9.34 & 0.41 & 3.25 & 3.08 & 7.38 & 0.37 & 4.9 & 6.4 & 0.6 & 0.2 \\
\hline IK 4 & $A$ & $0-10$ & Paleustoll & $4 / 3$ & $\mathrm{~s}$ & nd & $c$ & 5.39 & 0.53 & 3.98 & 0.92 & 7.17 & 0.25 & 3.6 & 22.4 & 1.1 & 0.6 \\
\hline IK 5 A & $A$ & $0-5$ & Paleustoll & $5 / 4$ & $\mathrm{~s}$ & nd & $\mathrm{cl}$ & 7.67 & 0.38 & 2.67 & 2.66 & 7.23 & 0.39 & 2.9 & 32.0 & 0.9 & 0.6 \\
\hline IK 5 B & Bw & $5-20$ & & $5 / 6$ & $\mathrm{~s}$ & nd & $\mathrm{cl}$ & 2.41 & 0.18 & 1.32 & 1.95 & 7.38 & 0.54 & 3.9 & 9.6 & 0.5 & 0.2 \\
\hline IK $6 \mathrm{~A}$ & $A$ & $0-6$ & Paleustoll & $3 / 4$ & $\mathrm{~s}$ & nd & $\mathrm{cl}$ & 3.32 & 0.54 & 5.34 & 5.08 & 6.87 & 0.23 & 4.1 & 22.4 & 0.7 & 0.7 \\
\hline IK 6 B & Bw & $6-17$ & & $4 / 4$ & $\mathrm{~s}$ & nd & $\mathrm{C}$ & 0.88 & 0.47 & 4.53 & 3.31 & 7.11 & 0.24 & 2.6 & 9.6 & 0.9 & 0.6 \\
\hline IK 7 A & $A$ & $0-7$ & Paleustoll & $4 / 4$ & s & nd & c & 2.67 & 0.23 & 2.88 & 2.29 & 6.71 & 0.36 & 4.4 & 16.0 & 0.6 & 0.2 \\
\hline IK 7 B & Bw & $7-30$ & & $4 / 6$ & $\mathrm{~s}$ & nd & $\mathrm{C}$ & 2.52 & 0.11 & 1.25 & 4.67 & 7.21 & 0.27 & 3.2 & 0.0 & 0.4 & 0.3 \\
\hline IK 8 & $A$ & $0-13$ & Paleustoll & $4 / 4$ & $\mathrm{~s}$ & 0 & $\mathrm{C}$ & 2.88 & 0.18 & 2.49 & 2.81 & 6.86 & 0.22 & 4.4 & 25.6 & 0.5 & 0.9 \\
\hline IK 9 & A & $0-16$ & Paleustoll & $3 / 4$ & $\mathrm{~s}$ & 7 & $\mathrm{C}$ & 3.05 & 0.22 & 2.72 & 2.84 & 7.24 & 0.30 & 4.4 & 99.2 & 0.5 & 4.7 \\
\hline IK 10 & A & $0-19$ & Paleustoll & $4 / 4$ & $\mathrm{~s}$ & 5 & $\mathrm{cl}$ & 1.92 & 0.27 & 3.05 & 2.53 & 6.65 & 0.17 & 5.1 & 38.4 & 0.7 & 0.6 \\
\hline IK 13 & A & $0-17$ & Paleustoll & $3 / 4$ & $\mathrm{~s}$ & nd & C & 2.69 & 0.33 & 4.49 & 1.59 & 7.10 & 0.27 & 5.6 & 35.2 & 0.5 & 3.0 \\
\hline IK 14 & $\mathrm{~A}$ & $0-15$ & Paleustoll & $5 / 4$ & $\mathrm{~s}$ & 1 & $\mathrm{cl}$ & 2.83 & 0.15 & 2.67 & 3.55 & 7.32 & 0.28 & 5.3 & 28.8 & 1.1 & 0.3 \\
\hline $\mathrm{IK} 16 \mathrm{~A}$ & $A$ & $0-19$ & Paleustoll & $3 / 2$ & $\mathrm{~s}$ & nd & $\mathrm{cl}$ & 3.16 & 0.42 & 5.37 & 1.34 & 7.38 & 0.34 & 5.2 & 41.6 & 1.4 & 0.7 \\
\hline IK 16 B & Bw & $19-30$ & & $4 / 4$ & $\mathrm{~s}$ & 15 & $\mathrm{Cl}$ & 3.63 & 0.10 & 2.52 & 1.56 & 7.38 & 0.40 & 4.6 & 3.2 & 1.0 & 0.3 \\
\hline NT 1 & $\mathrm{~A} / \mathrm{B}$ mixed & $0-27$ & Paleustoll & $3 / 4$ & $\mathrm{~s}$ & 0 & $\mathrm{cl}$ & 1.62 & 0.38 & 5.23 & nd & 7.49 & 0.68 & 7.2 & 38.4 & 0.7 & 0.0 \\
\hline NT $2 \mathrm{~A}$ & $A$ & $0-15$ & Paleustoll & $3 / 4$ & $\mathrm{~s}$ & 0 & $\mathrm{scl}$ & 2.11 & 0.50 & 6.24 & nd & 7.03 & 0.36 & 7.5 & 28.8 & 0.6 & 0.2 \\
\hline NT 2 B & Bw & $15-30$ & & $4 / 4$ & $\mathrm{~s}$ & 0 & $\mathrm{scl}$ & 10.70 & 0.35 & 3.82 & nd & 7.78 & 0.45 & 5.9 & 12.8 & 0.8 & 0.0 \\
\hline NT $4 \mathrm{~A}$ & $A$ & $0-15$ & Paleustalf & $2.5 / 2$ & $\mathrm{~s}$ & 58 & sl & 9.39 & 0.93 & 11.37 & nd & 7.35 & 0.00 & 8.7 & 105.6 & 1.3 & 1.1 \\
\hline NT $4 \mathrm{~B}$ & $\mathrm{Bt}$ & $15-26$ & Argillic H. & $3 / 3$ & $\mathrm{~s}$ & 52 & $\mathrm{cl}$ & 11.81 & 0.68 & 7.35 & nd & 7.72 & 0.51 & 7.3 & 19.2 & 1.1 & 0.0 \\
\hline NT 5 A & $A$ & $0-15$ & Paleustoll & $4 / 6$ & $\mathrm{~s}$ & 0 & c & 0.88 & 0.22 & 3.03 & nd & 6.72 & 0.34 & 5.0 & 224.0 & 0.5 & 0.0 \\
\hline NT 5 B & Bw & $15-23$ & & $4 / 6$ & $\mathrm{~s}$ & 0 & C & 0.64 & 0.10 & 2.90 & nd & 6.89 & 0.36 & 6.5 & 22.4 & 0.6 & 0.0 \\
\hline NT 6 & A & $0-8$ & Paleustoll & $4 / 6$ & $\mathrm{~s}$ & 13 & $\mathrm{cl}$ & 1.63 & 0.52 & 6.38 & nd & 7.42 & 0.43 & 7.7 & 76.8 & 0.8 & 0.3 \\
\hline NT 7 & A & $0-10$ & Paleustoll & $3 / 4$ & $\mathrm{~s}$ & 28 & $\mathrm{cl}$ & 3.62 & 0.96 & 10.47 & nd & 7.25 & 0.67 & 10.7 & 115.2 & 1.2 & 1.5 \\
\hline NT 8 & A & $0-10$ & Paleustoll & $3 / 4$ & $\mathrm{~s}$ & 0 & $\mathrm{cl}$ & 2.63 & 0.77 & 9.87 & nd & 7.54 & 0.71 & 10.1 & 211.2 & 0.9 & 2.2 \\
\hline NT 9 & $A$ & $0-9$ & Paleustoll & $3 / 4$ & $\mathrm{~s}$ & 0 & $\mathrm{cl}$ & 3.67 & 0.73 & 9.16 & nd & 7.45 & 0.64 & 12.9 & 118.4 & 0.6 & 1.5 \\
\hline NT 10 & A & $0-22$ & Paleustoll & $2.5 / 2$ & $\mathrm{~s}$ & 21 & $\mathrm{cl}$ & 10.81 & 0.45 & 7.77 & nd & 7.77 & 0.48 & 9.9 & 105.6 & 0.4 & 0.3 \\
\hline NT 11 & A & $0-13$ & Paleustoll & $2.5 / 2$ & $\mathrm{~s}$ & 11 & $\mathrm{sl}$ & 1.35 & 0.35 & 6.23 & nd & 7.29 & 0.44 & 7.2 & 73.6 & 0.6 & 0.9 \\
\hline
\end{tabular}




\begin{tabular}{|c|c|c|c|c|c|c|c|c|c|c|c|c|c|c|c|c|c|}
\hline NT 13 & A & $0-14$ & Paleustoll & $4 / 4$ & $\mathrm{~s}$ & 0 & $\mathrm{cl}$ & 2.01 & 0.50 & 6.79 & nd & 6.94 & 4.50 & 7.8 & 83.2 & 1.1 & 0.2 \\
\hline NT 15 & A & $0-13$ & Paleustoll & $3 / 4$ & $\mathrm{~s}$ & 7 & $\mathrm{cl}$ & 1.36 & 0.35 & 5.16 & nd & 7.46 & 0.37 & 6.5 & 41.6 & 1.1 & 0.3 \\
\hline NT 16 A & $A$ & $0-10$ & Paleustoll & $3 / 4$ & $s$ & 0 & $\mathrm{C}$ & 1.94 & 0.44 & 5.57 & nd & 7.53 & 0.24 & 7.8 & 147.2 & 1.2 & 0.0 \\
\hline NT 16 B & Bw & $10-20$ & & $4 / 6$ & $\mathrm{~s}$ & 22 & 1 & 3.15 & 0.25 & 3.45 & nd & 7.73 & 0.38 & 6.7 & 64.0 & 1.1 & 1.6 \\
\hline ET 1 & $A$ & $5-10$ & Paleustoll & $2.5 / 2$ & $\mathrm{~s}$ & 0 & $\mathrm{cl}$ & 1.61 & 0.37 & 5.61 & nd & 7.05 & 0.45 & 6.1 & 60.8 & 0.6 & 0.3 \\
\hline ET 1 & $\mathrm{Bt}$ & $20-25$ & & $4 / 4$ & $s$ & 12 & $\mathrm{sl}$ & 1.91 & 0.17 & 3.03 & nd & 7.48 & 0.28 & 5.5 & 16.0 & 0.8 & 0.1 \\
\hline ET 3 & A & 5 & Paleustalf & $2.5 / 2$ & $s$ & 18 & $\mathrm{cl}$ & 4.23 & 0.36 & 5.84 & nd & 7.65 & 0.40 & 8.1 & 240.0 & 0.3 & 0.9 \\
\hline ET 3 & $\mathrm{Bt}$ & 30 & Argillic H. & $3 / 3$ & $\mathrm{~s}$ & 26 & $\mathrm{C}$ & 19.15 & 0.13 & 3.19 & nd & 7.57 & 0.38 & 6.7 & 9.6 & 0.5 & 0.0 \\
\hline ET 3 & $\mathrm{Ck}$ & $45-50$ & Calcic H. & $4 / 4$ & $s$ & 40 & $\mathrm{cl}$ & 50.20 & nd & 2.28 & nd & 7.64 & 0.36 & 6.9 & 22.4 & 0.6 & 0.1 \\
\hline ET 4 & $A$ & $5-10$ & Paleustalf & $4 / 6$ & $\mathrm{~s}$ & 0 & $\mathrm{scl}$ & 0.85 & 0.24 & 3.75 & nd & 7.02 & 0.22 & 7.6 & 115.2 & 0.5 & 0.2 \\
\hline ET 4 & $\mathrm{Bt}$ & $30-40$ & Argillic $\mathrm{H}$. & $4 / 6$ & $\mathrm{~s}$ & 0 & $\mathrm{scl}$ & 1.53 & 0.09 & 2.56 & nd & 7.62 & 0.26 & 4.1 & 51.2 & 0.4 & 0.0 \\
\hline ET 5 & $A$ & $5-10$ & Paleustoll & $4 / 6$ & $\mathrm{~s}$ & 0 & $\mathrm{scl}$ & 0.91 & 0.15 & 3.33 & nd & 7.02 & 0.18 & 4.3 & 92.8 & 0.5 & 0.2 \\
\hline ET 5 & $\mathrm{Bt}$ & $20-25$ & & $3 / 4$ & $\mathrm{~s}$ & 0 & $\mathrm{scl}$ & 1.02 & 0.17 & 3.37 & nd & 7.14 & 0.32 & 5.6 & 48.0 & 0.5 & 0.2 \\
\hline ET 8 & A & $5-10$ & Paleustalf & $3 / 3$ & $\mathrm{~s}$ & 42 & sl & 24.47 & 1.28 & 14.76 & nd & 7.41 & 0.90 & 9.2 & 192.0 & 0.9 & 2.4 \\
\hline ET 8 & $\mathrm{Bk}$ & 35 & Argillic H. & $5 / 4$ & $\mathrm{~s}$ & 40 & $\mathrm{scl}$ & 56.10 & 0.47 & 12.60 & nd & 7.53 & 0.56 & 7.0 & 32.0 & 0.9 & 0.3 \\
\hline ET 9 & $A$ & $5-10$ & Calciustoll & $3 / 3$ & $\mathrm{~s}$ & 13 & I & 3.52 & 0.55 & 7.35 & nd & 7.52 & 0.63 & 5.4 & 54.4 & 0.5 & 0.4 \\
\hline ET 9 & Bw & $25-30$ & & $3 / 4$ & $\mathrm{~s}$ & 33 & $\mathrm{scl}$ & 18.64 & 0.41 & 7.72 & nd & 7.59 & 0.43 & 5.1 & 25.6 & 0.6 & 0.2 \\
\hline ET 10 & A & $0-10$ & Paleustoll & $4 / 6$ & $\mathrm{~s}$ & 37 & $\mathrm{cl}$ & 4.36 & 0.80 & 9.37 & nd & 7.58 & 0.57 & 5.7 & 105.6 & 0.8 & 0.8 \\
\hline ET 11 & A & $5-10$ & Paleustoll & $4 / 6$ & $\mathrm{~s}$ & 0 & 1 & 1.00 & 0.32 & 4.59 & nd & 6.54 & 0.56 & 4.8 & 57.6 & 0.6 & 0.2 \\
\hline ET 12 & $A$ & $5-10$ & Paleustoll & $3 / 4$ & $\mathrm{~s}$ & 0 & $\mathrm{scl}$ & 1.11 & 0.33 & 4.78 & nd & 6.91 & 0.45 & 5.9 & 51.2 & 0.6 & 0.2 \\
\hline ET 12 & Bw & 55 & & $4 / 6$ & $\mathrm{~s}$ & 0 & $\mathrm{scl}$ & 1.20 & 0.16 & 2.90 & nd & 7.32 & 0.41 & 7.5 & 28.8 & 0.4 & 0.0 \\
\hline ET 13 & A & $5-10$ & Paleustoll & $3 / 3$ & $s$ & 35 & $\mathrm{scl}$ & 5.20 & 0.80 & 9.51 & nd & 7.34 & 0.88 & 7.0 & 128.0 & 0.6 & 1.1 \\
\hline ET 14 & $A$ & $5-10$ & Paleustoll & $4 / 6$ & $\mathrm{~s}$ & 0 & $\mathrm{cl}$ & 1.26 & 0.27 & 4.27 & nd & 7.23 & 0.45 & 4.9 & 54.4 & 0.7 & 0.2 \\
\hline ET 14 & Bw & $15-20$ & & $5 / 6$ & $\mathrm{~s}$ & 0 & $\mathrm{scl}$ & 1.24 & 0.12 & 2.95 & nd & 7.35 & 0.19 & 7.2 & 35.2 & 0.3 & 0.0 \\
\hline ET 15 & $A$ & $5-10$ & Paleustalf & $3 / 4$ & $\mathrm{~s}$ & 0 & Is & 2.13 & 0.70 & 9.68 & nd & 6.93 & 0.96 & 7.0 & 169.6 & 0.5 & 0.7 \\
\hline ET 15 & Bw & $15-20$ & Argillic H. & $4 / 6$ & $\mathrm{~s}$ & 0 & $\mathrm{cl}$ & 2.01 & 0.44 & 5.67 & nd & 7.29 & 0.55 & 6.7 & 19.2 & 0.9 & 0.2 \\
\hline ET 16 & $\mathrm{~A} 1$ & $5-10$ & Calciustoll & $3 / 3$ & $\mathrm{~s}$ & 18 & $\mathrm{scl}$ & 12.27 & 0.85 & 11.90 & nd & 7.49 & 0.65 & 7.4 & 80.0 & 0.6 & 1.2 \\
\hline ET 16 & $\mathrm{~A} 2$ & $15-20$ & & $4 / 4$ & $\mathrm{~s}$ & 60 & sl & 24.20 & 0.54 & 10.10 & nd & 7.53 & 0.46 & 6.6 & 32.0 & 0.8 & 0.3 \\
\hline NW 17 & $\mathrm{~A} 2$ & $15-20$ & Paleustoll & $3 / 3$ & $\mathrm{~s}$ & 26 & $\mathrm{cl}$ & 6.91 & 0.62 & 8.62 & nd & 7.16 & 0.52 & 6.3 & 32.0 & 1.2 & 1.4 \\
\hline NW 20 & nd & nd & & $4 / 4$ & $s$ & 17 & $\mathrm{cl}$ & 3.11 & 0.80 & 10.60 & nd & 7.18 & 0.66 & 9.4 & 54.4 & 0.7 & 1.6 \\
\hline NW 23 & $A$ & $5-10$ & Calciustoll & $3 / 4$ & $\mathrm{~s}$ & 49 & $\mathrm{cl}$ & 12.80 & 0.90 & 9.62 & nd & nd & nd & 8.8 & 48.0 & 0.7 & 0.8 \\
\hline NW 23 & Bw & nd & & $5 / 4$ & $\mathrm{~s}$ & 26 & $\mathrm{cl}$ & 24.28 & 0.47 & 9.15 & nd & nd & nd & 7.6 & 12.8 & 0.8 & 0.4 \\
\hline NW 24 & $A$ & $5-10$ & Paleustalf & $4 / 6$ & s & 17 & $\mathrm{cl}$ & 1.53 & 0.23 & 3.44 & nd & 7.00 & 0.28 & 4.9 & 9.6 & 0.4 & 0.4 \\
\hline NW 24 & B1t & 30 & Argillic H. & $4 / 6$ & s & 25 & $\mathrm{C}$ & 2.72 & 0.02 & 1.15 & nd & 7.39 & 0.28 & 5.3 & 12.8 & 0.3 & 0.1 \\
\hline NW 24 & $\mathrm{~B} 2$ & $35-40$ & & $4 / 6$ & $\mathrm{~s}$ & 7 & $\mathrm{cl}$ & 2.92 & 0.01 & 1.20 & nd & 7.37 & 0.22 & 5.2 & 0.0 & 0.4 & 0.1 \\
\hline
\end{tabular}




\begin{tabular}{|c|c|c|c|c|c|c|c|c|c|c|c|c|c|c|c|c|c|}
\hline NW 25 & $A$ & nd & Paleustalf & $3 / 3$ & s & 73 & $\mathrm{scl}$ & 28.97 & 1.20 & 20.40 & nd & nd & nd & 5.1 & 150.4 & 0.5 & 2.1 \\
\hline NW 25 & Bw & 20 & Argillic H. & $5 / 6$ & $\mathrm{~s}$ & 27 & $\mathrm{cl}$ & 24.35 & 0.30 & 9.58 & nd & 7.40 & 0.52 & 8.2 & 16.0 & 0.8 & 0.3 \\
\hline NW 26 & $\mathrm{Bt}$ & $20-25$ & nd & $4 / 6$ & $\mathrm{~s}$ & 10 & $\mathrm{cl}$ & 1.39 & 0.07 & 2.61 & nd & nd & nd & 5.7 & 3.2 & 0.3 & 0.1 \\
\hline NW 27 & Bt1 & 30 & & $4 / 6$ & $\mathrm{~s}$ & 9 & $\mathrm{cl}$ & 1.96 & 0.02 & 0.98 & nd & 7.38 & 0.23 & 5.4 & 6.4 & 0.3 & 0.5 \\
\hline NW 27 & $\mathrm{Bt} 2$ & 50 & nd & $4 / 6$ & $\mathrm{~s}$ & 8 & $\mathrm{cl}$ & 1.94 & 0.04 & 1.44 & nd & 7.18 & 0.37 & 5.4 & 6.4 & 0.4 & 0.1 \\
\hline NW 28 & $A$ & $15-20$ & Paleustoll & $4 / 6$ & $\mathrm{~s}$ & 13 & $\mathrm{C}$ & 2.68 & 0.23 & 3.61 & nd & 6.78 & 0.19 & 4.7 & 6.4 & 0.8 & 0.3 \\
\hline NW 28 & $\mathrm{Bw} / \mathrm{Bt}$ & 35 & & $4 / 6$ & $\mathrm{~s}$ & 11 & $\mathrm{cl}$ & 2.59 & 0.08 & 2.16 & nd & 7.30 & 0.31 & 6.1 & 6.4 & 0.7 & 0.1 \\
\hline NW 29 & A2/A3 & 20 & Calciustoll & $3 / 2$ & $\mathrm{~s}$ & 32 & $\mathrm{cl}$ & 37.36 & 0.38 & 8.54 & nd & 7.28 & 0.54 & 6.2 & 6.4 & 0.9 & 0.2 \\
\hline NW 30 & Bw & 20 & Calcic H. & $5 / 4$ & $\mathrm{~s}$ & 17 & $\mathrm{cl}$ & 26.21 & 0.22 & 7.22 & nd & 7.37 & 0.27 & 4.8 & 3.2 & 0.7 & 0.2 \\
\hline NW 30 & nd & nd & & $4 / 4$ & $\mathrm{~s}$ & 23 & $\mathrm{cl}$ & 20.19 & 0.11 & 5.10 & nd & 7.39 & 0.53 & 5.3 & 6.4 & 1.3 & 0.1 \\
\hline NW 31 & $\mathrm{Bw}$ & nd & nd & $4 / 6$ & $\mathrm{~s}$ & 17 & $\mathrm{cl}$ & 4.11 & 0.44 & 5.87 & nd & 7.15 & 0.38 & 5.3 & 35.2 & 1.3 & 0.2 \\
\hline NW 32 & nd & 20 & nd & $4 / 6$ & $\mathrm{~s}$ & 16 & $\mathrm{cl}$ & 2.05 & 0.20 & 3.61 & nd & 7.37 & 0.34 & 5.1 & 25.6 & 1.0 & 0.2 \\
\hline NW 33 & $A$ & $5-10$ & Paleustoll & $3 / 6$ & $\mathrm{~s}$ & 7 & $\mathrm{cl}$ & 1.98 & 0.49 & 6.52 & nd & nd & nd & 4.7 & 51.2 & 0.5 & 0.8 \\
\hline NW 34 & nd & nd & & $4 / 4$ & $\mathrm{~s}$ & 16 & $\mathrm{C}$ & 3.20 & 0.33 & 4.86 & nd & 7.23 & 0.35 & 5.4 & 99.2 & 1.1 & 0.5 \\
\hline NW 36 & $A$ & nd & Paleustoll & $2.5 / 2$ & $\mathrm{~s}$ & 10 & c & 1.26 & 0.32 & 5.03 & nd & 6.29 & 0.73 & 5.3 & 86.4 & 0.3 & 0.6 \\
\hline NW 36 & $\mathrm{Bt}$ & $20-25$ & & $3 / 4$ & $\mathrm{~s}$ & 25 & $\mathrm{C}$ & 1.61 & 0.25 & 3.70 & nd & 7.16 & 0.55 & 5.5 & 19.2 & 0.2 & 0.3 \\
\hline NW 38 & $A$ & $5-10$ & Paleustoll & $3 / 3$ & $\mathrm{~s}$ & nd & $\mathrm{cl}$ & 1.35 & 0.34 & 5.53 & nd & 6.63 & 0.65 & 6.3 & 166.4 & 0.3 & 0.7 \\
\hline NW 38 & $\mathrm{Bt}$ & 20 & & $4 / 6$ & $\mathrm{~s}$ & 13 & $\mathrm{cl}$ & 1.12 & 0.27 & 3.62 & nd & 7.27 & 0.32 & 5.1 & 3.2 & 0.5 & 0.2 \\
\hline
\end{tabular}

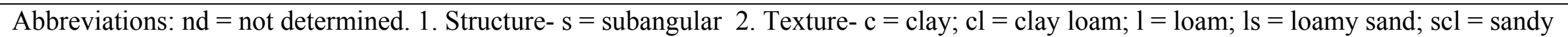
clay loam; sl = sandy loam. 
Table A-2 b. Descriptive Statistics: Kancab

\begin{tabular}{|c|c|c|c|c|c|c|c|c|c|c|c|c|c|c|c|c|}
\hline & $\begin{array}{l}\text { Profile } \\
\text { Depth }\end{array}$ & chr/value & \%Gravel & \%Sand & \%Silt & \%Clay & $\begin{array}{c}\% \mathrm{CaCO} 3 \\
\text { equiv }\end{array}$ & $\begin{array}{c}\text { Tot. } \\
\mathrm{N}\end{array}$ & $\begin{array}{l}\text { Tot. } \\
\text { O.C. }\end{array}$ & $\begin{array}{c}\text { \%BC } \\
\text { of } \\
\text { O.C. } \\
\end{array}$ & $\mathrm{pH}$ & $\mathrm{EC}$ & $\begin{array}{c}\mathrm{P}- \\
\mathrm{mg} / \mathrm{kg}\end{array}$ & $\mathrm{K}-\mathrm{mg} / \mathrm{kg}$ & $\begin{array}{c}\mathrm{Cu}- \\
\mathrm{mg} / \mathrm{kg}\end{array}$ & $\begin{array}{c}\mathrm{Zn}- \\
\mathrm{mg} / \mathrm{kg}\end{array}$ \\
\hline Mean & 21.10 & 1.15 & 14.27 & 38.76 & 28.02 & 33.22 & 4.51 & 0.49 & 6.41 & 2.35 & 7.15 & 0.53 & 6.37 & 84.51 & 0.72 & 0.83 \\
\hline Standard Error & 1.81 & 0.05 & 3.01 & 1.92 & 1.06 & 1.30 & 0.86 & 0.04 & 0.54 & 0.40 & 0.05 & 0.10 & 0.32 & 9.14 & 0.04 & 0.13 \\
\hline Median & 20.00 & 1.00 & 7.00 & 33.09 & 29.01 & 34.75 & 2.68 & 0.40 & 5.45 & 2.53 & 7.23 & 0.39 & 5.64 & 75.20 & 0.63 & 0.58 \\
\hline Mode & 20.00 & 1.00 & 0.00 & 42.56 & 30.16 & 33.71 & $\# / A$ & N/A & N/A & N/A & 7.23 & 0.45 & 4.40 & 105.60 & 0.66 & 0.00 \\
\hline Standard Deviation & 11.60 & 0.30 & 18.32 & 12.71 & 7.02 & 8.65 & 5.72 & 0.28 & 3.60 & 1.32 & 0.33 & 0.67 & 2.09 & 60.61 & 0.28 & 0.89 \\
\hline Sample Variance & 134.59 & 0.09 & 335.74 & 161.63 & 49.26 & 74.76 & 32.71 & 0.08 & 12.97 & 1.75 & 0.11 & 0.45 & 4.38 & 3673.69 & 0.08 & 0.79 \\
\hline Kurtosis & 1.06 & -0.20 & 2.22 & 0.66 & 0.02 & 1.07 & 10.01 & 0.60 & 4.27 & 0.77 & -0.24 & 32.30 & 0.94 & 0.17 & -0.42 & 8.05 \\
\hline Skewness & 1.05 & 0.41 & 1.59 & 1.18 & -0.18 & -0.94 & 3.05 & 1.07 & 1.76 & 0.46 & -0.43 & 5.40 & 1.00 & 0.90 & 0.79 & 2.55 \\
\hline Range & 53.00 & 1.33 & 73.00 & 52.50 & 31.37 & 41.78 & 28.12 & 1.13 & 17.91 & 4.83 & 1.48 & 4.50 & 9.95 & 233.60 & 1.08 & 4.71 \\
\hline Minimum & 2.00 & 0.67 & 0.00 & 22.92 & 12.07 & 7.50 & 0.85 & 0.15 & 2.49 & 0.26 & 6.29 & 0.00 & 2.91 & 6.40 & 0.33 & 0.00 \\
\hline Maximum & 55.00 & 2.00 & 73.00 & 75.42 & 43.44 & 49.28 & 28.97 & 1.28 & 20.40 & 5.08 & 7.77 & 4.50 & 12.86 & 240.00 & 1.40 & 4.71 \\
\hline Sum & 865.00 & 50.45 & 528.00 & 1705.45 & 1232.80 & 1461.75 & 198.25 & 21.74 & 282.04 & 25.87 & 293.00 & 21.75 & 280.10 & 3718.40 & 31.46 & 36.64 \\
\hline Count & 41 & 44 & 37 & 44 & 44 & 44 & 44 & 44 & 44 & 11 & 41 & 41 & 44 & 44 & 44 & 44 \\
\hline Conf. Level(95.0\%) & 3.66 & 0.09 & 6.11 & 3.87 & 2.13 & 2.63 & 1.74 & 0.08 & 1.10 & 0.89 & 0.11 & 0.21 & 0.64 & 18.43 & 0.09 & 0.27 \\
\hline
\end{tabular}


Table A-3. Saklu'um All: Physical and Chemical Properties

\begin{tabular}{|c|c|c|c|c|c|c|c|c|c|c|c|c|c|c|c|c|c|}
\hline $\begin{array}{c}\text { Sample } \\
\text { Name }\end{array}$ & Horizon & $\begin{array}{c}\text { Depth } \\
\text { (cm) }\end{array}$ & $\begin{array}{l}\text { Great } \\
\text { Group }\end{array}$ & $\begin{array}{l}\text { Soil Color } \\
\text { Dry } 2.5 \mathrm{Y}\end{array}$ & $\mathrm{Str}^{1}$ & \%Gravel & $\begin{array}{l}\text { Text }^{2} \\
\text { Class }\end{array}$ & $\begin{array}{c}\mathrm{CaCO} 3 \text { equiv } \\
\end{array}$ & $\begin{array}{l}\text { Total N } \\
--\%-\cdots-- \\
\end{array}$ & Total O.C. & $\begin{array}{c}\text { Black Carbon } \\
\% \text { of O.C. }\end{array}$ & $\mathrm{pH}$ & EC & P-mg/kg & $\mathrm{K}-\mathrm{mg} / \mathrm{kg}$ & Cu-mg/kg & Zn-mg/kg \\
\hline PO 1 & A & $0-12$ & Endoaquent & $5 / 4$ & $\mathrm{~s}$ & 0 & $\mathrm{sl}$ & 2.09 & 0.85 & 6.77 & 1.26 & 7.65 & 1.6 & 6.5 & 19.2 & 0.1 & 0.2 \\
\hline PO 11 & $A$ & $0-12$ & Endoaquent & $4 / 2$ & $\mathrm{~s}$ & 0 & $\mathrm{cl}$ & 4.17 & 0.83 & 7.93 & 0.88 & 7.57 & 0.7 & 9.4 & 35.2 & 0.0 & 0.1 \\
\hline PO 16 & $A$ & $0-17$ & Petraquept & $7 / 2$ & $\mathrm{~s}$ & 0 & $\mathrm{C}$ & 62.79 & 0.29 & 4.47 & 0.58 & 7.71 & 1.5 & 8.2 & 51.2 & 0.1 & 0.0 \\
\hline PO 19 & $A$ & $0-10$ & Endoaquent & $4 / 3$ & $\mathrm{~s}$ & 4 & sl & 9.97 & 1.82 & 17.30 & 0.26 & 7.69 & 0.7 & 13.3 & 108.8 & 0.1 & 0.3 \\
\hline PO 20 & $A$ & $0-3$ & Endoaquent & $5 / 2$ & $\mathrm{~s}$ & 9 & 1 & 43.79 & 1.39 & 14.65 & 0.28 & 7.68 & 1.1 & 14.7 & 147.2 & 0.0 & 0.2 \\
\hline NA 2 & $A$ & $0-3$ & Endoaquent & $7 / 2$ & $g$ & 0 & $\mathrm{cl}$ & 84.91 & 0.55 & 4.21 & 0.62 & 7.47 & 1.7 & 16.7 & 86.4 & 1.0 & 0.5 \\
\hline NA 7A & $A$ & $0-2$ & Petraquept & $3 / 1$ & $\mathrm{~s}$ & 63 & nd & 40.86 & 1.38 & 14.90 & 0.24 & 7.73 & 0.6 & 6.1 & 195.2 & 3.3 & 4.6 \\
\hline NA 7B & $\mathrm{Ck}$ & $2-17$ & Calcic H. & $7 / 2$ & $\mathrm{~s}$ & 43 & $\mathrm{scl}$ & 55.96 & 0.50 & 4.78 & 0.96 & 7.73 & 1.4 & 10.2 & 41.6 & 1.2 & 0.0 \\
\hline NA $8 A$ & $A$ & $0-1$ & Endoaquent & $7 / 2$ & $\mathrm{~s}$ & 0 & $\mathrm{cl}$ & 88.23 & 0.39 & 3.41 & 0.42 & 7.48 & 1.3 & 11.2 & 96.0 & 0.8 & 0.9 \\
\hline NA 8B & $\mathrm{Ck}$ & $1-3$ & & $8 / 2$ & $\mathrm{~s}$ & 0 & $\mathrm{C}$ & 89.20 & 0.29 & 2.10 & 0.51 & 7.52 & 2.0 & 11.8 & 64.0 & 1.0 & 0.2 \\
\hline NA 9A & $A$ & $0-2$ & Endoaquent & $6 / 2$ & $\mathrm{~s}$ & 0 & $\mathrm{scl}$ & 61.80 & 0.40 & 5.68 & 0.58 & 7.66 & 0.6 & 13.3 & 320.0 & 0.7 & 0.8 \\
\hline NA 9B & $\mathrm{Ck}$ & $2-10$ & & $7 / 2$ & $\mathrm{~s}$ & 0 & $\mathrm{cl}$ & 69.20 & 0.25 & 2.10 & 0.54 & 7.57 & 1.7 & 6.1 & 25.6 & 0.6 & 0.0 \\
\hline
\end{tabular}

Abbreviations: $\mathrm{nd}=$ not determined. 1 . Structure- $\mathrm{g}=$ granular; $\mathrm{s}=$ subangular 2 . Texture- $\mathrm{c}=\mathrm{clay} ; \mathrm{cl}=\mathrm{clay}$ loam; $1=$ loam; $\mathrm{scl}=\mathrm{sandy} \mathrm{clay}$

loam; sl = sandy loam. 
Table A-3 b. Descriptive Statistics: Saklu'um

\begin{tabular}{|c|c|c|c|c|c|c|c|c|c|c|c|c|c|c|c|c|}
\hline & $\begin{array}{l}\text { Profile } \\
\text { Depth } \\
\end{array}$ & chr/value & \%Gravel & \%Sand & $\%$ Silt & \%Clay & $\begin{array}{l}\text { \%CaCO3 } \\
\text { equiv } \\
\end{array}$ & $\begin{array}{l}\text { Tot. } \\
\mathrm{N} \\
\end{array}$ & $\begin{array}{l}\text { Tot. } \\
\text { O.C. }\end{array}$ & $\begin{array}{l}\% B C \\
\text { of } \\
\text { O.c. } \\
\end{array}$ & $\mathrm{pH}$ & $\mathrm{EC}$ & $\begin{array}{l}\mathrm{P}- \\
\mathrm{mg} / \mathrm{kg}\end{array}$ & $\mathrm{K}-\mathrm{mg} / \mathrm{kg}$ & $\begin{array}{l}\mathrm{Cu}- \\
\mathrm{mg} / \mathrm{kg}\end{array}$ & $\begin{array}{l}\mathrm{Zn}- \\
\mathrm{mg} / \mathrm{kg}\end{array}$ \\
\hline Mean & 9.67 & 0.44 & 8.49 & 42.25 & 28.50 & 29.00 & 44.29 & 0.88 & 8.81 & 0.57 & 7.63 & 1.08 & 11.05 & 117.69 & 0.68 & 0.83 \\
\hline Standard Error & 1.87 & 0.07 & 6.93 & 3.94 & 1.18 & 3.46 & 11.06 & 0.18 & 1.78 & 0.11 & 0.03 & 0.16 & 1.24 & 31.24 & 0.36 & 0.49 \\
\hline Median & 10.00 & 0.33 & 0.00 & 41.00 & 28.50 & 28.00 & 43.79 & 0.83 & 6.77 & 0.58 & 7.66 & 1.10 & 11.25 & 96.00 & 0.11 & 0.25 \\
\hline Mode & 3.00 & 0.29 & 0.00 & $\# N / A$ & 27.00 & $\# N / A$ & \#N/A & $\# N / A$ & $\# N / A$ & \#N/A & $\# N / A$ & 0.70 & 13.27 & $\# N / A$ & $\# N / A$ & \#N/A \\
\hline Standard Deviation & 5.61 & 0.20 & 20.79 & 11.16 & 3.34 & 9.78 & 33.19 & 0.54 & 5.33 & 0.33 & 0.10 & 0.47 & 3.71 & 93.72 & 1.07 & 1.46 \\
\hline Sample Variance & 31.50 & 0.04 & 432.06 & 124.50 & 11.14 & 95.71 & 1101.29 & 0.29 & 28.39 & 0.11 & 0.01 & 0.22 & 13.75 & 8782.79 & 1.14 & 2.13 \\
\hline Kurtosis & -1.39 & -0.09 & 8.44 & -2.06 & -0.66 & -1.02 & -1.52 & -0.89 & -1.42 & 1.26 & -0.76 & -1.97 & -1.31 & 1.93 & 5.81 & 7.93 \\
\hline Skewness & -0.07 & 1.21 & 2.88 & 0.08 & -0.25 & 0.36 & -0.07 & 0.65 & 0.70 & 1.17 & -0.89 & 0.11 & 0.03 & 1.35 & 2.31 & 2.77 \\
\hline Range & 14.00 & 0.51 & 63.32 & 28.00 & 10.00 & 28.00 & 86.14 & 1.53 & 13.89 & 1.03 & 0.26 & 1.15 & 10.56 & 300.80 & 3.31 & 4.64 \\
\hline Minimum & 3.00 & 0.29 & 0.00 & 28.00 & 23.00 & 17.00 & 2.09 & 0.29 & 3.41 & 0.24 & 7.47 & 0.55 & 6.12 & 19.20 & 0.03 & 0.00 \\
\hline Maximum & 17.00 & 0.80 & 63.32 & 56.00 & 33.00 & 45.00 & 88.23 & 1.82 & 17.30 & 1.26 & 7.73 & 1.70 & 16.69 & 320.00 & 3.34 & 4.64 \\
\hline Sum & 87.00 & 3.97 & 76.38 & 338.00 & 228.00 & 232.00 & 398.60 & 7.90 & 79.32 & 5.12 & 68.64 & 9.70 & 99.45 & 1059.20 & 6.13 & 7.51 \\
\hline Count & 9 & 9 & 9 & 8 & 8 & 8 & 9 & 9 & 9 & 9 & 9 & 9 & 9 & 9 & 9 & 9 \\
\hline Conf. Level(95.0\%) & 4.31 & 0.15 & 15.98 & 9.33 & 2.79 & 8.18 & 25.51 & 0.41 & 4.10 & 0.26 & 0.07 & 0.36 & 2.85 & 72.04 & 0.82 & 1.12 \\
\hline
\end{tabular}



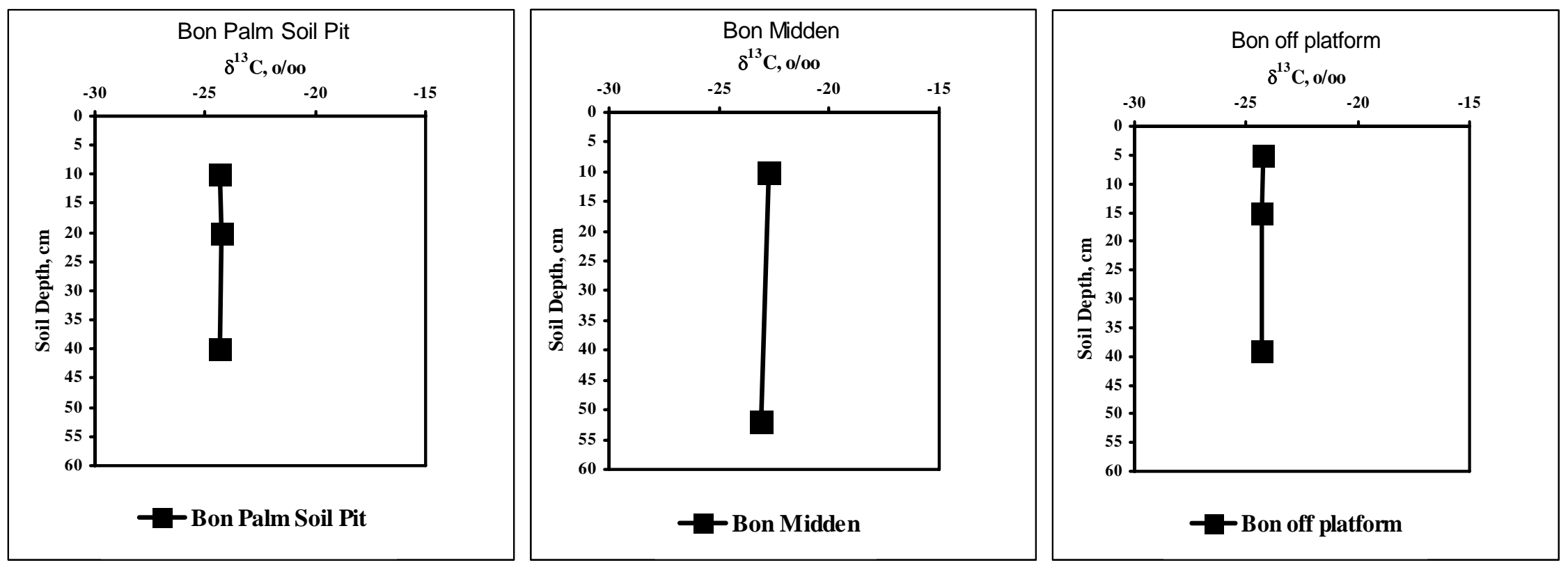

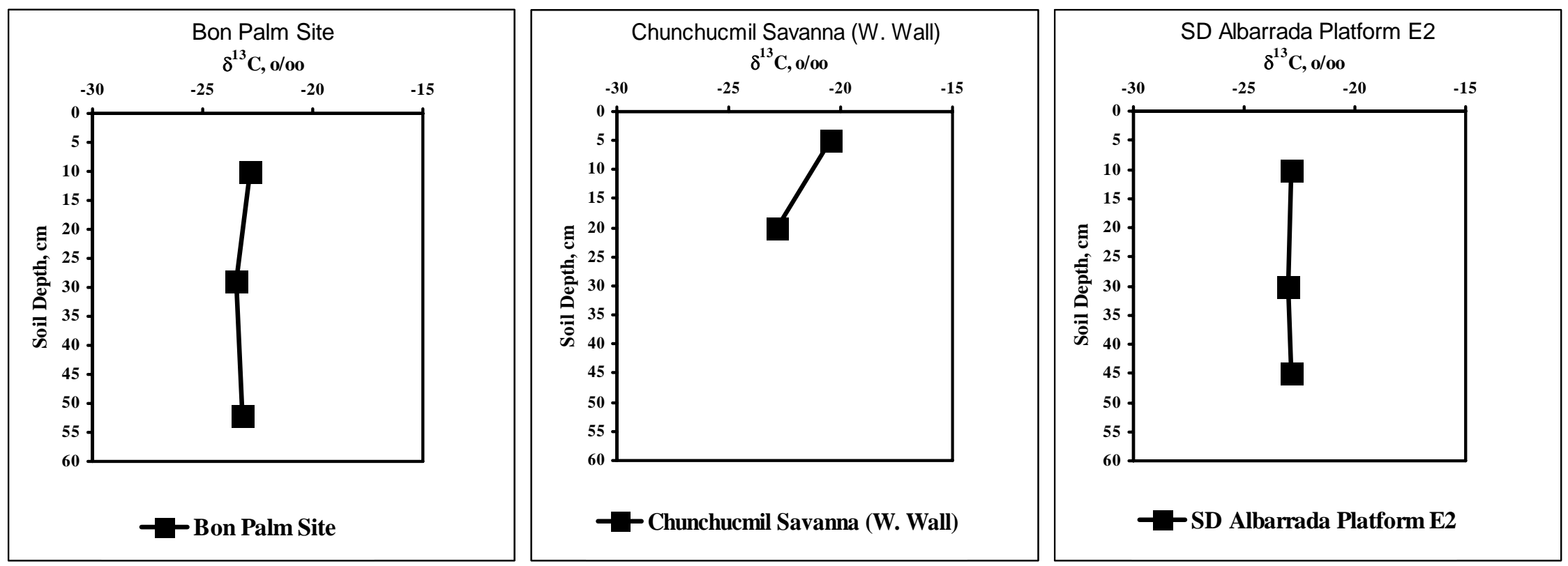

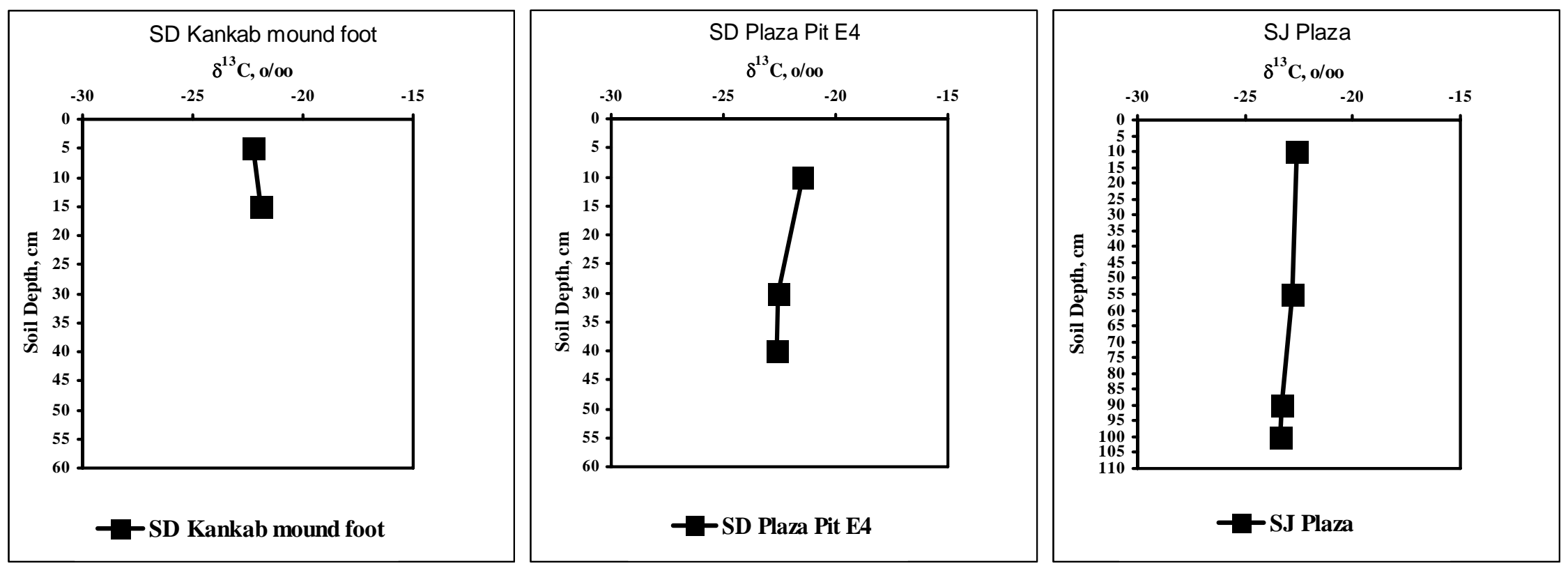


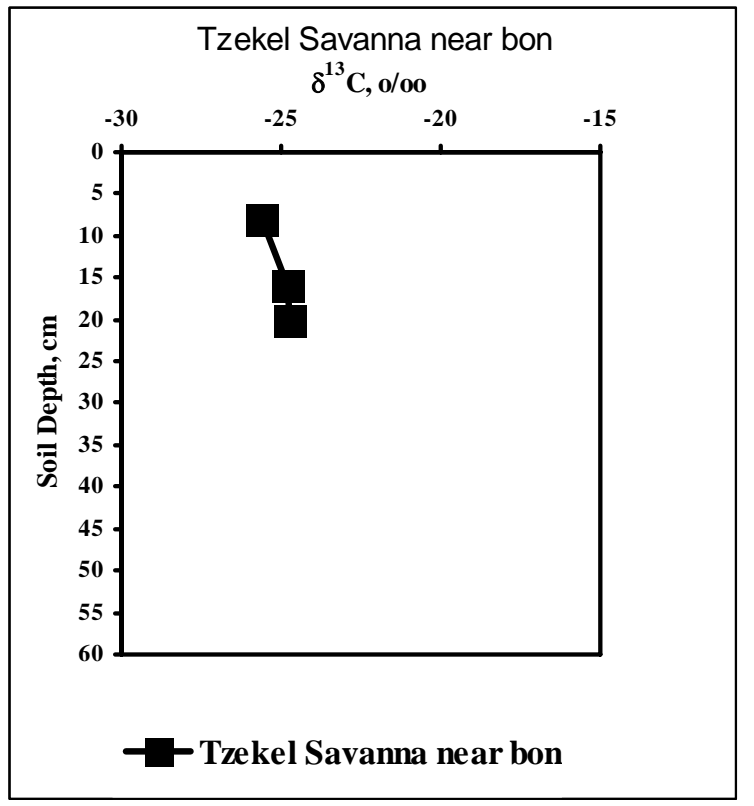

